\title{
In the Style of Toleration: \\ Bevis Marks and the Synagogue Architecture of Seventeenth-Century London
}

\author{
Elizabeth Ann Mitchell \\ BA Architectural Studies, University of Washington, 2009 \\ BA Mathematics, University of Washington, 2009 \\ A thesis presented to the Graduate Faculty \\ of the University of Virginia in Candidacy for the Degree \\ of Master of Architectural History
}

May, 2014

Shiqiao Li

Sheila Crane

Louis Nelson 


\section{Abstract}

This project is on the Spanish and Portuguese Jewish community living in London during the 17th century and their synagogues at Creechurch Lane and Bevis Marks. In 1656, a small congregation of Sephardic Jewish merchants emerged in the city of London. These were the first openly practicing Jews residing in England since the Jewish Expulsion in 1290. Following the Inquisitions on the Iberian Peninsula, Sephardic Jews developed an intricate network, connecting major port cities like Amsterdam and London, that allowed them to become highly successful in their mercantile practices. In London, their financial success provided them with a respectable social status and the means to construct worship spaces that were admired by the general public. This thesis argues that the synagogue architecture of the first Jewish community in Early Modern London is testament to the growing religious tolerance that existed in English political thought as early as the mid-17th century, and demonstrates this congregation's success in peacefully securing their social and economic status within English society. Their first synagogue in a remodeled residence on Creechurch Lane, followed by the purpose-built, still extant Bevis Marks, display the skilled independent building projects commissioned in London outside of the major patron that dominated English Architecture, the Royal Office of Works headed famously by Sir Christopher Wren. The architectural discussion is focused on design precedent for their synagogue, Bevis Marks, which includes the Esnoga in Amsterdam, and Christopher Wren's city churches. The broader political, religious and architectural trends of the period are also discussed in depth, including the shared interest amongst Jews and Christians in physical reconstructions of Solomon's Temple. It is during this period that Jewish synagogues and Protestant churches borrowed from each other to such a high degree that they become practically interchangeable. These trends demonstrate the flaw in assigning a linear trail of architectural influence to Bevis Marks Synagogue. Instead, Creechurch Lane and Bevis Marks, along with other religious spaces contemporary to the period, like Wren's churches and the Esnoga, existed within the same climate and together tell a larger story of the trends in religious architecture of the 17th century. 


\section{Acknowledgments}

This thesis could not have been started, nor completed, without the unwavering support of my advisors at the University of Virginia. In particular, thank you to Shiqiao Li, the chair of this MA thesis, as well as Sheila Crane, Louis Nelson, and Lisa Reilly, for providing invaluable feedback at every stage of this project. Also, to the Interdisciplinary Graduate Fellows of Jewish Studies, led this past year by Asher Biemann, for providing a welcoming venue to share and discuss my ongoing research. And, of course, thank you to my family for their unconditional love, that is the reason I have the courage to take on these intellectual challenges in the first place. 


\section{Table of Contents}

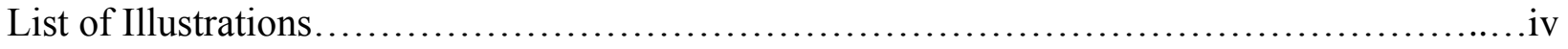

\section{Chapter 1}

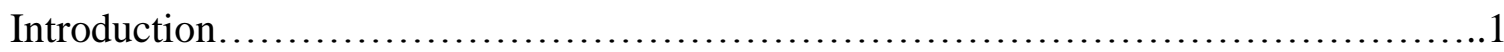

Chapter 2

Inquisition and Toleration:

Religious and Political Climate of Seventeenth-Century Europe......................9

Chapter 3

A Community Emerges:

The Spanish and Portuguese Jews of Seventeenth Century London...................24

Chapter 4

Bevis Marks Synagogue:

The Architecture of an English-Jewish Congregation............................41

Chapter 5

Return to the Temple of Jerusalem:

Parallel Themes in Synagogue and Church Architecture

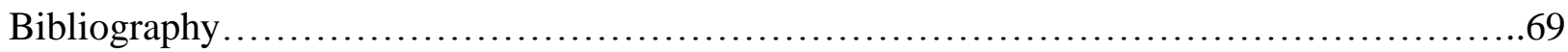

Illustrations .................................................................. 76 


\section{Illustrations}

figure 1: Bevis Marks Synagogue, London. Main entrance and courtyard beyond gate. 76

figure 2: Example of Jewish badge in England, in the shape of the Tablets of Law. Flores historiarum, England, early $14^{\text {th }}$ century. London, British Library MS. Cotton Nero D.ii, folio 183 verso (image: Mellinkoff, Ruth. Outcasts: Signs of Otherness in Northern European Art of the Late Middle Ages. Berkeley: University of California Press, 1993.

figure 3: Map of Locations of Jews in Medieval England before Expulsion in 1290, Capital letters indicate towns where archæ (all deeds, pledges, mortgages, lands, houses, rents, and possessions of registered Jews) were deposited; italics, towns from which Jews were expelled prior to 1290 (image: jewishencyclopedia.com)

figure 4: Map of London, highlighted area gives the location of the mid to late-seventeenth century Jewish community. John Strype, Survey of London, published in 1720 (image: http://www.hrionline.ac.uk/strype/).

figure 5: Aldgate Ward, London. Spanish and Portuguese Jewish neighborhood, mid to lateseventeenth century. Key buildings highlighted. (image: John Strype's Survey of London,

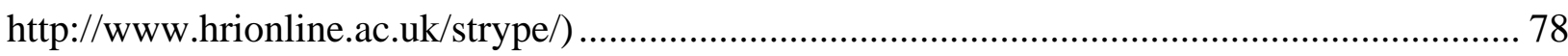

figure 6: Portrait of Menasseh ben Israel by Rembrandt, 1654 ............................................ 79

figure 7: St. Katherine Creechurch, London (image: Wikimedia Commons) ............................ 79

figure 8: Creechurch Lane Synagogue, London. Floor Plans, 1657. Reconstructed from evidence found in various documents and drawn by Manuel N. Castello, A.R.I.B.A. (image: Samuel, Wilfred S. "The First London Synagogue of the Resettlement [Creechurch Lane]." Transactions of the Jewish Historical Society of England 10 (1924): 1-147.)

figure 9: The Great Gate leading into Duke's Place, Aldgate Ward, London. A print from 1825 showing its demolition 1816, after having stood since 1280. (image: Samuel, 1924).....

figure 10: Creechurch Lane Synagogue, London. Floor Plans after remodel in 1674.

Reconstructed from evidence found in various documents and drawn by Manuel N. Castello, A.R.I.B.A. (image: Samuel, 1924).

figure 11: The 'Jews Synagogue' as a 'Place of Interest' in London, see arrows. Composite image from a map printed in 1735 , but based on the $17^{\text {th }}$ century survey of Thomas Jeffreys (image: Samuel, 1924)

figure 12: Bevis Marks Synagogue, London. East interior view towards Ark (Echal). (image: author) 82

figure 13: St Bride's Fleet Street, London. Street view (image: Wikimedia Commons) 82 
figure 14: St. James Piccadilly, London. Exterior circa 1815 (image: Wikimedia Commons).... 83 figure 15: Merchant Taylors' Hall, London. Entry way designed by Joseph Avis for Robert Hooke. Destroyed during WWII. (image: http://www.roberthooke.org.uk/) ........................... 83

figure 16: Bevis Marks Synagogue, London. Ark (Echal) (image: author)............................. 84

figure 17: Bevis Marks Synagogue, London. Drawing of interior by M. Bellisario, late $18^{\text {th }} \mathrm{c}$. (image: http://www.jewishmuseum.org.uk/) .... 84

figure 18: The Spanish and Portuguese Synagogue (Esnoga), Amsterdam. Exterior view across canal (synagogue on right). Oil painting by Gerrit Adriaensz Berckheyde (Haarlem 1638-1698), Amsterdam: view of the Portuguese and the Grote Synagogues. (image: Wikimedia Commons)

figure 19: Temple at Charenton, France. Exterior view. Built 1623 by architect Solomon de Brosse, demolished 1685. (image: http://museeprotestant.org/) ........................................ 85

figure 20: Temple at Charenton, France. Interior view. (image: http://museeprotestant.org/) ..... 86 figure 21: Spanish and Portuguese Synagogue (Esnoga), Amsterdam. Interior of the Portuguese Synagogue, Emanuel de Witte (1617-1692), oil painting, 1680 (image: Wikimedia Commons) 86 figure 22: Christ Church New Gate, London. Plan, longitudinal section (image: Wren, Christopher. "The Parochial Churches of Sir Christopher Wren, 1666-1718." In Publications, v. 9-10, edited by Arthur T Bolton and H Duncan Hendry. Oxford: Printed for the Wren Society at the University Press, 1932.)

figure 23: St Peter, Cornhill, London. Engraving circa 1820-30 (image:

http://christchurchartgallery.org.nz/)

figure 24: St Clement Dames in the Strand, London. Modern interior view towards alter (reconstructed after WWII damage). (image: Wikimedia Commons). 88

figure 25: St Bride's, Fleet Street, London. Interior view, west towards Organ. Photo taken circa 1920, before damage from WWII. Photographer: S O Gorse (image: http://viewfinder.englishheritage.org.uk/). 88

figure 26: St James Piccadilly, London. Modern interior view towards east end and alter (reconstructed after WWII damage). (image: Wikipedia Commons).

figure 27: St. James Piccadilly, London. Plan, east exterior and interior elevations. (image: Wren, Christopher. "The Parochial Churches of Sir Christopher Wren, 1666-1718." In Publications, $v$. 9-10, edited by Arthur T Bolton and H Duncan Hendry. Oxford: Printed for the Wren Society at the University Press, 1932.)..... 89

figure 28: Bevis Marks Synagogue, London. Ground floor plan. Based on drawing by Barbara Bowman, published in Kadish, Sharman. Bevis Marks Synagogue: A Short History of the Building and an Appreciation of Its Architecture. Swindon: English Heritage, 2002. 90 
figure 29: Bevis Marks Synagogue, London. Interior, detail of columns and wainscoting. Benches in view originally constructed for Creechurch Lane and brought to Bevis Marks. (image: author).

figure 30: Bevis Marks Synagogue, London. Site plan from 1896 “ordnance Survey” map of synagogue area. From sheet VII- 66. (image: http://maps.nls.uk/)....

figure 31: The Spanish and Portuguese Synagogue (Esnoga), Amsterdam. Modern exterior street view. (image: Wikimedia Commons)

figure 32: The Spanish and Portuguese Synagogue (Esnoga), Amsterdam. Main entrance and elevation (image: Wikipedia Commons)

figure 33: Depiction of Solomon's Temple complex, engraving from an edition of Jacob Judah Leon's Afbeelding van den Tempel Salomonis, Amsterdam, 1644 (image:

http://www.mhs.ox.ac.uk/)

figure 34: Bevis Marks, London. Gate into courtyard, view from street (image: Wikipedia Commons) 93

figure 35: Bevis Marks Synagogue, London. Main entrance and elevation (image: author) ....... 93

figure 36: Bevis Marks Synagogue, London. Front entrance. (image: author) ..... 94

figure 37: St. Bride's, Fleet Street, London. Exterior elevations and plan. (image: Wren, Christopher. "The Parochial Churches of Sir Christopher Wren, 1666-1718." In Publications, $v$. 9-10, edited by Arthur T Bolton and H Duncan Hendry. Oxford: Printed for the Wren Society at the University Press, 1932.). 94 figure 38: Bevis Marks Synagogue, London. North exterior elevation. (image: author) 95 figure 39: Bevis Marks Synagogue, London. South exterior elevation (now part of restaurant on site) (image: author).

figure 40: Bevis Marks Synagogue, London. West exterior elevation, from Heanage Lane (image: author).

figure 41: The Spanish and Portuguese Synagogue (Esnoga), Amsterdam. Buttressing detail. (image: Wikimedia Commons).

figure 42: The Spanish and Portuguese Synagogue (Esnoga), Amsterdam. Ground floor plan, from the engraving by Romeyn de Hooghe (1645-1708) celebrating its opening in 1675. (image: Rubens, Kenneth. "Bevis Marks Synagogue and the City Churches." Transactions of the Jewish Historical Society of England 37 (2002): 117-31.).

figure 43: The Spanish and Portuguese Synagogue (Esnoga), Amsterdam. Interior view east towards Ark (Echal) (image: Wikimedia Commons)

figure 44: Bevis Marks Synagogue, London. Reading desk (bimah) and candles. (image: author) 
figure 45: Bevis Marks Synagogue, London. Ceiling rosette details. (image: author)............... 98

figure 46: St Benet Paul's Warf, London. Interior view towards east altar (image: author) ........ 99

figure 47: Bevis Marks Synagogue, London. West interior view, including curved railing and other details (image: author)

figure 48: View of the Tabernacle of Moses, ritual objects, and wagons of the Israelites.

Illustration printed in Retrato del tabernaculo de Moseh, Amsterdam, 1654 (image: Rosenau, Helen. Vision of the Temple: The Image of the Temple of Jerusalem in Judaism and Christianity.

London: Oresko Books, 1979.). 100

figure 49: Depiction of Solomon's Temple Complex, illustration printed in Retrato del tabernaculo de Moseh, Amsterdam, 1654 (image: Rosenau, Helen. Vision of the Temple: The Image of the Temple of Jerusalem in Judaism and Christianity. London: Oresko Books, 1979.)

figure 50: Depiction of Tabernacle of Moses, illustration printed in Retrato del tabernaculo de Moseh, Jacob Judah Leon, Amsterdam, 1654 (image: http://www.mhs.ox.ac.uk/) .... 101

figure 51: Diagram of Solomon's Temple by Isaac Newton, Chronology of Ancient Kingdoms Amended (image: http://www.mhs.ox.ac.uk/).... 101

figure 52: El Escorial, Spain. Ground plan based on depictions of Solomon's Temple Complex (image: Wikipedia Commons)..... 102 figure 53: Ground plan of Temple Precincts, Plan of Solomon's Temple Complex, Juan Bautista Villalpando, In Ezechielem Explanationes (image: Rosenau, Helen. Vision of the Temple: The Image of the Temple of Jerusalem in Judaism and Christianity. London: Oresko Books, 1979.)

figure 54: Detail of Solomon's Temple Complex, Juan Bautista Villalpando, In Ezechielem Explanationes ( image: http://www.mhs.ox.ac.uk/).

figure 55: Solomon's Temple Elevation, Juan Bautista Villalpando, In Ezechielem Explanationes (image: http://www.mhs.ox.ac.uk/)

figure 56: Reredos with Tablets of Law, flanked by paintings of Biblical figures Aaron and Moses. St Anne and St Agnes church in London (image: Wikimedia Commons). figure 57: St Benet Paul's Warf, London. Reredos including Tablets of Law. (image: author) 104 figure 58: Ashkenazi Great Synagogue of London, destroyed during WWII. Engraving by Pugin, published in Microcosm of London (1810) (image: Wikimedia Commons) ..... 105 


\section{1}

\section{Introduction}

At a recent conference hosted by the Graduate Fellows in Jewish Studies at the University of Virginia, I had a conversation with a professor in the German department, Dr. Gabriel Finder, who perfectly summed up the reason why I began this academic journey. Having presented my paper on the synagogues of the seventeenth-century London Jewish community, Dr. Finder, a Jewish historian on the Holocaust, reminisced fondly about his personal visit to Bevis Marks, a synagogue that opened its doors in 1701 London. In the same way two people discuss a shared memory, something cherished by only those lucky enough to be in on a wellkept secret, he commented that, "London synagogues are something special, aren't they?"

Bevis Marks Synagogue is not an obscure building to Jewish scholars; at over three hundred years old, it is the oldest, purpose built, continually used synagogue in Western Europe, and a central stop on London's Jewish historical walking tours (figure 1). To those without a cultural or academic connection to this Jewish heritage site however, Bevis Marks, an orthodox Sephardic synagogue, could remain completely unnoticed. This is the story of the religious architecture of the Spanish and Portuguese, Sephardic-Jewish community living in seventeenth century London. Their synagogues, the first at Creechurch Lane, later demolished, and followed by Bevis Marks, display the skilled independent building projects commissioned in London, outside of the major patron that dominated English Architecture, the Royal Office of Works 
headed famously by Sir Christopher Wren. My goal in this thesis is to fit a synagogue like Bevis Marks into the existing dialogue on religious architectural trends in England and Continental Europe during a period in which major shifts occurred in political, economic, and religious thinking. Seventeenth-century England was home to a wide number of Christian denominations, all fighting for security and status. As a result of this conflict, and epitomized in the writing of John Locke, religious tolerance became a central part of England's political identity. This provided a unique opportunity for European Jews, whose lives had been shaped by the conditions of centuries of expulsion and movement, to enter mainstream western society. This is the first stage of my research on the role of architecture in the creation of a tolerant community, with London's early modern Sephardic congregation as a case study. I argue that the synagogue architecture of the first openly practicing Jewish community in early modern London is testament to the growing religious tolerance that existed in English political thought as early as the mid-seventeenth century, and demonstrates this congregation's success in peacefully securing their social and economic status within English society.

London, the city of Westminster Abbey and St. Paul's Cathedral, is not commonly known for its synagogue architecture. In fact, the rich history of Jews in England, which spans back to William the Conqueror's Norman invasion in 1066, is missing from England's central historical narrative. During the medieval period, when the sin of usury was a common subject of Christian sermons, Jews who lived in Christian territories took on the role as money-lenders, in addition to a wide variety of other occupations outside Christian guild organizations. Their role as lenders to borrowers across social hierarchies - from kings and bishops, to their Christian neighbors made them vital to the economies of the places they were allowed to settle, and influential to the built environment itself, as financial providers for the construction and upkeep of cathedrals, 
abbeys, fortifications and homes. ${ }^{1}$ In medieval England, Jews lived under royal charters, which provided the minority population legal protection and the right to live within Christian communities. However, they were heavily taxed and their lives closely monitored through monetary institutions like the Exchequer of the Jews. ${ }^{2}$ Jews in medieval England were certainly seen as 'other' in the Christian society; their orthodox customs outside Catholic ritual made them stand out, in addition to the badges they were forced to wear (figure 2). ${ }^{3}$ However, they were not necessarily an exotic community; their presence would have been familiar to Christians in cities throughout England until their expulsion during the reign of Edward II in 1290 (figure 3). ${ }^{4}$

Even after the Jewish expulsion, Jews played a critical role in the formation of English identity, through their fictionalized depictions as an 'other' in Christian sermons, plays and popular myth, especially the stories of blood libel and ritual murder, which began in England and resulted in violence against entire Jewish communities across Europe. ${ }^{5}$ As Geraldine Heng comments in her discussion on race in the middle ages, Jews were not just incidental, but

\footnotetext{
${ }^{1}$ This is a very new line of research. For more on the role of Jewish lenders on the built environment in Medieval England, see Kathy Lavezzo. "The Minster and the Privy: Rereading The Prioress's Tale," PMLA 126, no. 2 (March 2011): 363-82.

${ }^{2}$ The Exchequer of the Jews, a division of the Court of Exchequer at Westminster, operated from the 1190's until the Jewish Expulsion in 1290. They recorded and regulated taxes and legal cases of the Jews in England. This high level of documentation regarding Jewish communities was unique to Medieval England, hence why modern historians understand considerably more regarding English Jews during the Middle Ages compared to other locales during the same period. These financial records can be currently found at the Public Record Office in London.

${ }^{3}$ The fourth Lateran council in 1215 required both Jews and Saracens to be distinguished visually from Christians. This ruling was interpreted in England as a yellow badge, in the shape of the Tablets of Law, that Jews were legally required to wear beginning in 1218. The Tablets of Law became a symbol by which Jews were recognized in person, but also in Christian imagery- the tablets held by the biblical figure Synagoga is one example. There was nothing negative in this association, merely a reference to the Hebrew Bible/Old Testament. For more, see Rowe, Nina. The Jew, the Cathedral and the Medieval City: Synagoga and Ecclesia in the Thirteenth Century. New York: Cambridge University Press, 2003; Sapir Abulafia, Anna. Christian-Jewish Relations, 1000-1300: Jews in the Service of Medieval Christendom. Harlow, England: Longman, 2011.

${ }^{4}$ Reasons for expulsion still debated, current thought suggests economic incentives and growing anti-Jewish sentiments. For current state of the field on Medieval English Jewry, see Mundill, Robin R. "Out of the Shadow and Into the Light: The Impact and Implications of Recent Scholarship on the Jews of Medieval England 1066-1290." History Compass 9, no. 8 (2011): 572-607.

${ }^{5}$ For an exceptional introduction to this complex topic, see Rubin, Miri. Gentile Tales: The Narrative Assault on Late Medieval Jews. New Haven, CT: Yale University Press, 1999; specific to England, see Krummel, Miriamne Ara. Crafting Jewishness in Medieval England: Legally Absent, Virtually Present. New York: Palgrave Macmillan, 2011.
} 
constitutive to the formation of England's history and their collective identity. ${ }^{6}$ Throughout the history of Christianity, the 'Jew' has played a complex role in theological debate, and caused real challenges for the Christian majority. Judaism has an indisputable historical role in Christianity, the re-appropriation of the Hebrew Bible as the Old Testament is the most obvious example, however, the fact that Judaism continued to be practiced bothered Christian theologians, and Jews were labeled as a highly stubborn people for not converting to the teachings of Christ. Recent generations of historians in Jewish Studies have worked tirelessly to remedy the marginalization of Jews in the history of England and Western Europe, but much work is still left to be done to challenge the prevailing view that Christianity was a singular shaping force of societal changes in the West, and that a synagogue like Bevis Marks is as valuable to our historic narrative as the churches of Christopher Wren.

In the field of architectural history, cathedrals and parish churches define English art and architecture to such a high degree, that even Nikolaus Pevsner, who was forced to flee Nazi Germany due to his Jewish birth, missed a large number of architecturally important synagogues in his Buildings of England. ${ }^{7}$ The primary scholar working to remedy this neglect of Jewish heritage sites in the UK is Sharman Kadish, who has published books on synagogues of the British Isles that range in audience from academic to travel guides. ${ }^{8}$ Prompted by a decline in England's modern Jewish population and a desire to preserve Jewish heritage sites, she led a

\footnotetext{
${ }^{6}$ Heng, Geraldine. "The Invention of Race in the European Middle Ages II: Locations of Medieval Race." Literature Compass 8, no. 5 (May 02, 2011): 275-93.

${ }^{7}$ This contradiction between Pevsner's own heritage and his legacy in the field of Architectural History is noted in the introduction of Kadish, Sharman. 2011. The Synagogues of Britain and Ireland: An Architectural and Social History. New Haven: Yale University Press. xii-xiii. Pevsner does however include Bevis Marks (called the Spanish and Portuguese Synagogue) in his Buildings of England.

${ }^{8}$ Kadish's books on the Jewish Built Heritage of England include Kadish, Sharman. The Synagogues of Britain and Ireland: An Architectural and Social History. New Haven: Yale University Press, 2011; Kadish, Sharman, ed. Building Jerusalem: Jewish Architecture in Britain. London; Portland: Vallentine Mitchell, 1996; and the guidebook, Kadish, Sharman. Jewish Heritage in England: An Architectural Guide. Swindon: English Heritage, 2006.
} 
survey across the UK and Ireland of over 350 Jewish architectural sites, from religious to secular, and published their findings. She regularly includes discussion of the seventeenthcentury community and their synagogue at Bevis Marks because, as she accurately notes, the site is "testimony to the stability of modern Jewish life in Britain." "However, in-depth research and analysis of the synagogue is lacking, as her goal of documenting not only this site but the numerous other Jewish monuments that require conservation efforts in England, is extremely ambitious.

As important as the Jewish Expulsion in 1290 is to Jewish historians of English history, the year 1656 is greeted with equal interest. This marks the year of the Official Resettlement of Jews in England, during the Commonwealth under Oliver Cromwell, and a major topic to be discussed in this thesis. I have many generations of Jewish historians to thank for their extensive archival research and publications on the first Jewish community living in London after the Resettlement. The Transactions of the Jewish Historical Society of England has provided scholars a place to discuss the considerable range of topics related to the history of Jews in England since the society first began meeting in 1893. The first president and foundational scholar on the seventeenth-century London Jewish community was Lucien Wolf, whose research continues to be expanded on within the context of this publication. ${ }^{10}$ Another historian of the early twentieth century, to whom I am greatly indebted, as is anyone who has studied London's first Jewish community, is Wilfred S. Samuel, who in the 1923 volume of TJHSE, published his

\footnotetext{
${ }^{9}$ Kadish, Sharman. "Constructing Identity: Anglo-Jewry Synagogue Architecture.” Architectural History 45, no. 2002 (2013): 386.

${ }^{10} \mathrm{~A}$ few of Wolf's pivotal articles, still regularly referenced, include: Wolf, Lucien. "Crypto-Jews Under The Commonwealth." Transactions of the Jewish Historical Society of England 1 (1893): 55-88; Wolf, Lucien. "The First English Jew: Notes on Antonio Ferdinando Carvajal, with Some Biographical Documents." Transactions of the Jewish Historical Society of England 2 (1894): 14-46; Wolf, Lucien. "Status of the Jews in England after the ReSettlement." Transactions of the Jewish Historical Society of England 4 (1899): 177-93.
} 
research on the first synagogue in London at Creechurch Lane. ${ }^{11}$ Samuel is responsible for uncovering the original location of this previously mysterious synagogue and its related primary sources- not a small accomplishment. The site's history left a limited trail of evidence for historians, and Samuel provides an in-depth record of the building's evolution from a repurposed worship space, to its remodeling into housing at the opening of Bevis Marks in 1701, and the demolition of the entire block when the street was widened in the nineteenth century. This was a significant find for English Jewish scholars and is sadly relegated to a single footnote in most published material on London synagogues- a major oversight that will be remedied in this thesis. For Samuel's paper, as well as many others, TJHSE provides extensive appendixes of facsimiles and transcriptions of archived documents, that have provided invaluable primary source material for my research. Further sources that have made this thesis possible are the historians who, working with the congregation leaders at Bevis Marks, published many of the synagogue's extensive records. This includes the congregation's early twentieth-century Rabbi, Moses Gaster, who published an impressive history of Bevis Marks in 1901, and Lionel D. Barnett, who compiled a six volume compendium of the synagogue's records in $1940 .^{12}$

While there is extensive prior research on the first London Jewish community of the early modern period, there are many avenues still left to explore - especially their synagogue architecture. There are a few short discussions currently available on Bevis Marks Synagogue,

\footnotetext{
${ }^{11}$ Samuel, Wilfred S. "The First London Synagogue of the Resettlement [Creechurch Lane]." Transactions of the Jewish Historical Society of England 10 (1924): 1-147.

${ }^{12}$ These historians stand out, along with Samuel, as having a high level of academic integrity, and remain reliable sources today- a rare find in early discussions regarding Bevis Marks. Gaster makes clear to his readers that he only wrote on material he had direct access to in the Synagogue's archives, and refused to write anything that could be perceived as hearsay, even if it had been written by prior historians. Many others, including Pevsner, were not this careful in their description of Bevis Marks, and repeated unverified gossip regarding the synagogue's past, which have led to rumors that go as far as Queen Anne personally providing a structural cross beam. I've tried to work with the same level of integrity in regards to my sources. Gaster, Moses. History of the Ancient Synagogue of the Spanish and Portuguese Jews. London: Bevis Marks, 1901; Barnett, Lionel D., ed. Bevis Marks Records: Being Contributions to the History of the Spanish and Portuguese Congregation of London. Oxford: University Press, 1940.
} 
one by Kadish and another, an article by Kenneth Rubens for TJHSE, both of which focus on the architectural influences on the building's design. ${ }^{13}$ Kadish supports the argument that the Sephardic community's mother synagogue in Amsterdam offered the major design inspiration, while Rubens argues that Christopher Wren's city churches provided an important local source for the London congregation. In no way do I intend to refute either of their arguments, but their papers are brief and lack important historical context related to this Jewish community. Instead, I hope to add a more comprehensive understanding of the synagogue's architecture by examining the complex circumstances of the people who worshipped there, an invaluable facet surprisingly lacking in current scholarship on Bevis Marks. To accomplish this, I will begin with a survey of the political and religious climate of Western Europe that brought these Spanish and Portuguese Jews to London in the mid-seventeenth century. Once that background is provided, chapters three and four will examine the details of the first London Jewish congregation following the Resettlement in 1656 up to the opening of Bevis Marks in 1701. Chapter three explores the two stages of construction at their first synagogue at Creechurch Lane, which was repurposed from a residence in 1657 , and underwent a major renovation and expansion in 1674 , that would offer important precedent to the design of Bevis Marks. Chapter four provides further context for the local and continental styles that likely also influenced the construction of the new synagogue. The final chapter considers this history through a wider perspective, to look at the trends in religious architecture and the parallels between Jewish and Protestant worship spaces during the period. By observing these broader themes, including the shared interest amongst Jews and Christians in physical reconstructions of the biblical site of Solomon's Temple, we can understand that the influences on the design of Bevis Marks are the same as those influencing the

\footnotetext{
${ }^{13}$ Kadish, Sharman. Bevis Marks Synagogue: A Short History of the Building and an Appreciation of Its Architecture. Swindon: English Heritage, 2002; Rubens, Kenneth. 2002. "Bevis Marks Synagogue and the City Churches." Jewish Historical Studies 37: 117-131.
} 
religious architecture in England and Northern Europe, including Wren's City Churches and the Esnoga in Amsterdam. Bevis Marks along with the worship spaces of various Protestant denominations of the late seventeenth and early eighteenth century, describe a moment when synagogues and churches, Jews and Christians, borrowed from each other to such a high degree that their worship spaces become practically interchangeable. This also happens to be a moment in which modern political concepts of religious toleration saw their early articulations in England and Northern Europe, and by providing both architectural details and the larger religious and political context, the untold story of religious toleration through design can begin to emerge. 


\section{2}

\section{Inquisition and Toleration: The Religious and Political Climate of Seventeenth-Century Europe}

On the $4^{\text {th }}$ of August 1657, the bells of St. Katherine Creechurch tolled once, as was the tradition, to mark the passing of a member of the parish community. Mrs. Judith de Brito, widow of a prominent London merchant, was being laid to rest; her casket covered with a borrowed pall from St. Katherine's churchwardens. ${ }^{14}$ The funeral however, did not take place in the expected churchyard, but in the newly opened Jewish cemetery at Mile End. De Brito was a member of London's small Jewish community, whose congregation had been officially established only the prior year. The community consisted of about thirty-five men of Portuguese descent, many with families, who lived in the outer limits of the city, within the parish of St Katherine Creechurch and neighboring wards of Aldgate and Duke's Place (figure 4). ${ }^{15}$ A month following Judith de Brito's death, another aging member of the new Jewish synagogue passed: Sarah Athias, the wife of the Rabbi of the new congregation. Again, one church bell sounded in honor of her passing. As time would have it, two years later a congregation elder found their place at Mile End; this time, a successful, well-known London merchant, Antonio Ferdinando Carvajal. Often referred to as 'The first English Jew,' Carvajal had been responsible for securing both the place of

\footnotetext{
${ }^{14}$ Samuel, 1924 , p. 24-25

${ }^{15}$ Katz, David. Philo-Semitism and the Readmission of the Jews to England, 1603-1655. Oxford; New York: Clarendon Press; Oxford University Press, 1982.
} 
worship as well as the cemetery for the new congregation. ${ }^{16}$ On his passing on October 28, 1659 , the parish church rang their 'Great Bell' five times, an act that honored the memory of a highly respected citizen of London. ${ }^{17}$

These small actions between church and synagogue are telling of the religious and social climate in this London parish in the middle of the seventeenth century; they paint a clear picture of tolerance between neighbors. At that moment, no laws existed in England regarding the status of Jews, so there was no legal reason to identify Jewish neighbors as part of the same population as the Christian majority. Yet, in this neighborhood, Jews and Christians not only lived and worked side by side, all were perceived to be active members and participants of a shared community (figure 5). Judith de Brito, Sarah Athias, Antonio Ferdinando Carvajal, and presumably their relations, were not seen as 'alien' or 'other' within their London neighborhood. This level of toleration would have been shocking only years earlier, and practically unthinkable to the generations of Jewish communities that had faced centuries of persecution in Europe. So what exactly had changed since England forcibly expelled Jews from its borders in 1290 that would allow this Jewish community to have such tolerant relations with their Christian neighbors?

For one, these were not the same Jews as those of the thirteenth century. And two, this was not the same England as the one ruled by Edward II. We would expect a lot to change in four centuries, and many things did. England had been the first country to expel the entire Jewish population from their borders, but it would begin a trend that continued for the following two centuries, almost completely eliminating Jewish life from Western and Central Europe. France

\footnotetext{
${ }^{16}$ Samuel, 1924, p. 23

${ }^{17}$ Samuel, 1924 , p. $24-25$
} 
expelled their Jewish communities in 1306, then again in $1394 .{ }^{18}$ Between 1350 and 1450, European communities faced the epidemic known as the Black Death, which brought with it a catastrophic loss of population and constricted economic activity, as well as high levels of violence against Jews. In Germany during the years of 1348-9, Jews were accused of poisoning wells, and entire communities were slaughtered in what is known as the Black Death massacres. ${ }^{19}$ During the late fourteenth-century in Spain, where Jews had enjoyed exceptionally favorable conditions and lived within one of the largest Jewish populations in Europe of around 200,000 Jewish men, women, and children, circumstances took a sharp turn for the worse. ${ }^{20} \mathrm{~A}$ massive outbreak of the plague in 1391 caused violent hysteria against dozens of large Jewish communities across the country, including those in Toledo, Burgos, Sevilla, and Valencia, and thousands of Jews were killed, while tens of thousands were forcibly baptized. ${ }^{21}$ By the midfifteenth century, Jews had been banned from cities in Central Europe, as well as in various cities in Italy into the sixteenth century. ${ }^{22}$ It is therefore apparent that when Spain began the Inquisition in 1481 and expelled all Jews who refused conversion in 1492, this was not a phenomenon unique to the Iberian peninsula, but can instead be seen within the wider context of Jewish persecution throughout Europe.

Even so, the expulsions from Spain in 1492 and Portugal in 1497 left a deep impact on the collective memory of the Jewish people of Europe, and became a central factor in the evolution of European Judaism. For the tens of thousands of Jews who had emigrated to Portugal from Spain in 1492, the Inquisition in Portugal brought another round of mass forced

\footnotetext{
${ }^{18}$ Kaplan, Debra. "Jews in Early Modern Europe: The Sixteenth and Seventeenth Centuries." History Compass 10, no. 2 (2012): p. 196

${ }^{19}$ Israel, Jonathan. European Jewry in the Age of Mercantilism, 1550-1750. Oxford; New York: Clarendon Press; Oxford University Press, 1985. p 5-6

${ }^{20}$ Israel, 1985

${ }^{21}$ Israel, 1985 , p. 6

${ }^{22}$ Kaplan, 2012, p. 192
} 
baptisms. Those who chose to leave the Iberian peninsula went to the Sephardic Jewish centers that had been established in Islamic territories during the centuries of European expulsions, primarily in North Africa and the Ottoman Empire in the Near East. ${ }^{23}$ Those who stayed and converted to Roman Catholicism were labeled as New Christians, and though they did settle into Christian society, they faced social discrimination and intimidation by the authorities of the Inquisition. Some New Christians looked for ways to maintain their Jewish identity, and a culture of crypto-Judaism, where Jewish rituals were practiced in secret, was developed in the Iberian Peninsula. This was especially true in Portugal, where the Inquisition was not an effective force until around $1580 .{ }^{24}$ Due to this strong crypto-Jewish population, Portugal would supply a continual flow of converso emigrants who followed Jewish customs to Jewish centers around the globe for centuries to follow.

By the beginning of the seventeenth century, the Western Christian world had been divided into two general principles of religious and political practice. The Reformation and Counter-Reformation had sent waves across Europe, changing the religious identity of the continent. The Spanish Inquisition, and those that followed in Portugal and Rome, represented the Roman Catholic world. Papal attitudes towards Jews and Judaism were hostile in the late sixteenth century; Catholic authorities believed Judaism to be a force capable of 'seducing' the minds of Christians, and more importantly, the recently converted New Christians. ${ }^{25}$ The policy against Jews of Pope Paul IV involved two major goals: to pressure Jews toward conversion and to keep the Christian world safe from Jewish influence. In 1555, Paul IV issued a papal bull which required Jews living in the Papal States to be segregated into ghettos - often over-crowed,

\footnotetext{
${ }^{23}$ Certain Islamic territories, and the Ottoman Empire in particular, were highly tolerant of Jews during the medieval and early modern periods. Kaplan, Yosef. "Bom Judesmo: The Western Sephardic Diaspora." In Cultures of the Jews: A New History, edited by David Biale, 638-69. 1st ed. New York: Schocken Books, 2002. p. 642

${ }^{24}$ Israel, 1985 , p. 24

${ }^{25}$ Israel, 1985, p. 18
} 
walled off areas, which further minimized interactions between Jews and Christians. ${ }^{26}$ His successor, Pius V, took these edicts further by expelling Jews from all Papal states, with the exception of the major port city of Ancona and Rome itself. ${ }^{27}$ The Inquisitions, controlled by the monarch of the given territory, were designed to root out all forms of heresy and enforce orthodox Catholicism within the borders of their realm. The trials, forced conversions, expulsions and executions by the authorities of the Inquisition enforced more than just the religious orthodoxy of the church, but also the political ideology of these Roman Catholic states. Spain in particular pushed forward this political ideology, in which, as a Christian state, it was the country's responsibility to do all within their power to embody Christian religious values. In response to the Reformation, Spanish monarchs viewed their own country as the heir of the chosen people of Israel and protectors of Catholic Christianity. ${ }^{28}$ This ideology led to the intense missionary practices, as well as Inquisitorial forces, throughout Spanish and Portuguese colonies. Major Spanish political thinkers of the seventeenth century, including Saavedra Fajardo and Fernandez de Navarrete, further promoted the importance of the Spanish monarch, as the key for the conservation of orthodox Roman Catholicism. ${ }^{29}$ As a result of this view, and the mass forced baptisms of the Inquisition, early modern Spain was consumed with ideas related to purity of Christian blood. Traditional religious law defined converts and their descendants as Christian in every respect, however, regulations of limpiezas de sangre were imposed in Spain and later Portugal, stating that it was not one's faith which determined their rights, but their lineage. ${ }^{30}$ Only those with uncontaminated 'Old Christian' backgrounds were considered to have 'pure

\footnotetext{
${ }^{26}$ Israel, 1985, p. 19

${ }^{27}$ Israel, 1985, p. 21

${ }^{28}$ Kaplan, Yosef. "Political Concepts in the World of Portuguese Jews of Amsterdam During the Seventeenth Cenutry: The Problem of Exclusion and the Boundaries of Self-Identity." In Menasseh Ben Israel and His World, edited by Yosef Kaplan, Henry Mechoulan, and Richard Popkin, 45-62. Leiden, 1989. p. 53

${ }^{29}$ Kaplan, 1989, p. 48-49

${ }^{30}$ Kaplan, 1989, p. 52
} 
blood.' New Christians, and their descendants, were blocked from participating in certain areas of society. By the mid-sixteenth century, laws related to blood purity reached almost every public institution- anyone wanting a government appointment, a religious order, military ranking, university positions, and the like, had to receive certification from the Inquisition testifying to their pure Old Christian bloodline. ${ }^{31}$ Into the seventeenth century, purity of blood as central to determining one's social position was a major characteristic of Spanish and Portuguese society.

The other side of the divide in religious and political thought in the wake of the Reformation and Counter-Reformation developed in Northern Europe, where Protestant denominations of Lutheranism and Calvinism had firmly taken root. The split of the Church into a number of rival doctrines caused major turmoil throughout the entire sixteenth century, but by the end of the period, a certain stalemate had occurred. In France, the Wars of Religion spanning the years 1562-94, did not result in any victors, though the Protestant Huguenots did receive an extensive compromise. ${ }^{32}$ Fighting between Protestants and Catholics in the Spanish controlled Netherlands came to an impasse, leaving the population split between the north and the south. Other countries in Central Europe - Germany, Switzerland and Poland - experienced similar outcomes in their religious debate, and in England, where the Anglican Church had been formed in the early sixteenth century, conflict between Protestant denominations would come to a head during the years of Civil War in the mid-seventeenth century. It was becoming clear to certain intellectuals that there would not be a clear victor in these religious wars, and the Christian world had reached an unprecedented deadlock. Scholars, including Michel de Montaigne, Jean Bodin, and Francis Bacon, wrestled with traditional Christian teachings, and pushed forward a new

\footnotetext{
${ }^{31}$ Kaplan, 1989, p. 52

${ }^{32}$ Israel, 1985, p. 37
} 
intellectual trend of radical skepticism. ${ }^{33}$ Their search was for what Bacon termed 'good and sound knowledge,' which was separate from the 'truths' that had been handed down from the past. The message from these writings was a focus on the present as liberated from historical circumstances, and these concepts made their way into the political and economic discussion of the period. In the view of certain political leaders, the only way for a country to move forward in the wake of religious wars, and restore unity and stability, was to look for new political solutions that were not based on the claims of the church, but instead the power of the state. Economic principles related to mercantilism, the pursuit of the economic advancement of the state regardless of religious or traditional values, also came out of this emergent intellectual thinking, which had separated the functions of the state from Christian ideology.

The city of Amsterdam in the Dutch Netherlands developed under the circumstances of these political and economic principles. The Netherlands had been under Spanish control until the Protestant Dutch revolt against Spain began in the late sixteenth century. During this period, the Jews themselves, who had been almost completely eliminated from the region, became central figures in the developing Dutch nation. Following the collapse of a stable government and the general turmoil that consumed the country, Dutch rebel leader, William of Orange turned to Jews for financial support in his efforts against Spain. ${ }^{34}$ From that point on, though somewhat intermittently depending on Spanish-Dutch relations, Jews in Western and Central Europe began to migrate towards the emergent port city of Amsterdam, which had a growing reputation for being tolerant towards non-Catholics. As the Dutch considered themselves and the Iberian Jews to share a common enemy in the Spanish Catholics, they welcomed the commercial activities of the Portuguese conversos, who were generally stereotyped by this period as being successful

\footnotetext{
${ }^{33}$ Israel, 1985, p. 36

${ }^{34}$ Israel, 1985, p. 50
} 
participants in the Portuguese colonial trade empire. During the Spanish and Dutch truce of 1609-21, it was over commercial issues that Spanish authorities became unhappy with their side of the bargain. ${ }^{35}$

In a partially unfounded accusation, that is telling of the insecurities of the period, Spanish authorities blamed the Portuguese converso Jews as the reason behind Dutch prosperity and Dutch colonial expansion. "With the help of the Jews [of Amsterdam]," wrote the Spanish priest Diego de Cisneros in an important 1637 memorial during the second Spanish-Dutch war, "the Dutch rebels have raised their head and increased their power, the Jews assisting them in their wars, conquests, negotiations and other pretensions and becoming in the lands of your Majesty, spies of the said rebels, penetrating the centres of trade, administration of the armadas, convoys and revenues of Your Majesty...sucking out the core of wealth [from Spain and Portugal] and sapping the resolutions of the state". ${ }^{36}$ It was believed that the Portuguese conversos, who lived secretly as Jews on the Iberian Peninsula and openly in Amsterdam, were undermining Spain's religious as well as commercial ambitions. There was some basis for this belief, as a number of successful merchants in the newly prosperous Amsterdam were in fact Portuguese conversos, who likely took advantage of their Iberian-Dutch connections during trade embargos with Spain. However they were a minority compared to the growing number of Dutch merchants, and there was also a large number of conversos living in poverty in Amsterdam, as well as a number of Portuguese New Christian merchants with no interest in returning to Judaism. Spanish authorities feared that the expansion and growing stability of Jewish life in Amsterdam would lead even more conversos to emigrate from the Iberian peninsula, bringing their trade activities with them and further expanding Dutch colonial activity. These fears can be

\footnotetext{
${ }^{35}$ Israel, Jonathan. "Spain and the Dutch Sephardim, 1609-1660." Studia Rosenthaliana 12, no. 1/2 (1978): 1 - 61.

${ }^{36}$ Translated in Israel, 1978, p. 2
} 
further understood through the lens of the mercantilist economic principles shared among colonial powers of the period, which included a general idea that global wealth was finite, and any gain for one country must be at the cost of another. In response to the Dutch truce, a Spanish secretary wrote to the state council in 1618 that, "the truce was very favorable to the Dutch and that since it was signed, they find themselves unhindered, with excessive wealth, while these realms [Spain, Portugal, Flanders, Naples, and Sicily] are much diminished, since the Dutch have taken their commerce, and that this damage, if not remedied, will become daily worse. ${ }^{37}$ The tides were turning for the Spanish and Portuguese colonial empire, as the Dutch fast approached their Golden Age of the seventeenth century.

As Amsterdam grew, so too did the city's Jewish population, especially the Sephardic community of Spanish and Portuguese conversos, who mainly identified themselves as Portuguese due to the ongoing unpopularity of Spain in the Netherlands. The conversos, who had been forced to follow Jewish ritual in secret, took the city's tolerance towards them as an opportunity to begin practicing openly again. The Spanish and Portuguese Jewish congregation grew rapidly in the seventeenth century and with Amsterdam's emergence as critical port city, it quickly became the center of the 'Nação Judeo Espanhola-Portuguesa', or 'Nación'. The Nación was a highly organized network of Iberian Jews, and included both those who fled from the Inquisition and those who remained in the Catholic country as conversos or New Christians. ${ }^{38}$ This made for a complex diaspora, where religious practices were not consistent between members, but it strengthened the family and business connections that made Portuguese Jews such assets in international trade. The identity of the Nación was further complicated- even

\footnotetext{
${ }^{37}$ Translated in Israel, 1978, p. 3

${ }^{38}$ Kaplan, 2002, p. 648
} 
though their diaspora had grown in strength due to the general religious tolerance of the Dutch, the Sephardim in Amsterdam was not a particularly tolerant group. According to scholars who have looked through the bookshelves of Portuguese Jews of Amsterdam, the community was extremely interested in political literature of the period, including a large number of Spanish authors sympathetic to the Spanish monarchs. ${ }^{39}$ From the commentary of Sephardic scholars, it appears that the political ideology of the Iberian peninsula ran deep, even within the Amsterdam Sephardic synagogue. In particular, Jewish authorities were highly concerned with the 'conservation' of the Nación, making an Iberian lineage significantly more important towards membership than one's commitment to Judaism. Traditional thinking also supported the concept of a 'religious state,' where ruler and residents lived under the same religious laws, and therefore certain rabbis applauded the Spanish Inquisition for rooting out heresy and expelling nonbelievers. ${ }^{40}$ This period was also marked by high levels of ethnocentric writing among Sephardic scholars, who promoted Jewish superiority and the concept of Jews as the 'chosen people'; the writing of Isaac Orobio, a Jew of converso background in Amsterdam, clearly differentiates between Judios Viejos, the decedents of Abraham, and Judios Nuevos, converts of Judaism who were not members of the Jewish nation. ${ }^{41}$

In addition to this political ideology, the leaders of the Amsterdam Spanish and Portuguese synagogue found themselves responsible for bringing religious orthodoxy to a congregation with a very mixed background in Judaism. The members of the congregation were decedents of Iberian Jews, whose Jewish customs had been forced into isolation for generations under the strict glare of the Inquisition, and many who returned to Judaism in Amsterdam were unfamiliar with the orthodoxy of the religion. There were also many instances of conversos

\footnotetext{
${ }^{39}$ Kaplan, 1989, p. 45

${ }^{40}$ Kaplan, 1989 , p. 50

${ }^{41}$ Kaplan, 1989, p. 56
} 
choosing to retain their Christian public identity, as well as those who returned to Judaism only to maintain commercial connections within the Nación. Either way, the large Sephardic congregation in Amsterdam was growing a reputation around Europe as being a place that Christians could witness the return of Jewish life to the continent. It was the wealthy members of the community who stood out to European Christians, or it was more that these Portuguese conversos, who had been immersed in Christian society for generations, did not appear distinctly 'alien' or 'other'. Christians were impressed with the wealth and success of these Portuguese Jews, who had proven themselves in global trade, were highly educated, and involved in the current wave of intellectual and theological debate. The congregation was well aware that the richest, and most elite among them were responsible for the high reputation their community had gained within Christian circles, leading the synagogue's ruling body to become very strict in an attempt to maintain the community's social status. They restricted membership in leadership positions to those with appropriate incomes, and offered high levels of financial assistance to their poor, in order to keep them from begging in the street. ${ }^{42}$ The congregation also provided aid to the poorer Ashkenazi Jews, who came from Central and Eastern Europe, however, these Jews could not be considered members of the Nación and rarely interacted socially with the Sephardic elite. $^{43}$ The Amsterdam synagogue's ruling body was also strict in their religious authority, and commonly excommunicated congregation members for unconventional writing. These excommunications, including that of Baruch Spinoza in 1656 and Juan de Prado in 1658, show that the Jewish community as a whole was experiencing similar internal disputes as those that had emerged in the Christian world. Many Jewish scholars, like Spinoza, were highly influenced

\footnotetext{
42 Kaplan, 2002, p. 638

${ }^{43}$ The split between the Ashkenazi and Sephardic Jews during this period was more across social boundaries than religious ones, and it was the Ashkenazi, who had been generally stereotyped as beggars, that continued to be viewed in a negative light by European Christians.
} 
by the trends of radical skepticism, and re-conceptualized orthodox Judaism in terms of these ideas and their own experience as conversos, where their crypto-Judaism had been an inner, intimate religious experience, not an all-encompassing way of life.

For both Christians and Jews, the sixteenth and early seventeenth century marked a period of internal conflict and transformation, and Amsterdam emerged as a progressive city, where a variety of religious practices were openly tolerated, and both Jews and Christians were recognized in the commercial prosperity of the Dutch trade empire. The Sephardic Jews who resided in Amsterdam became such an established presence in the city, that many European travelers significantly over-estimated the actual population of the Jewish community. ${ }^{44}$ Curious Christian visitors could commonly be found during services at the Spanish and Portuguese synagogue, whose community had become a popular travel destination. For many Protestant theologians, eager for a renewed understanding of the Hebrew Bible, the emergence of Sephardic scholars in Amsterdam, with their European educations, multi-lingual abilities and familiarity with Christian teaching, provided the ideal resource for theological and philosophical discussions. Even though the synagogue leaders prohibited theological debate, for fear of arousing anger against Jews, the intellectual trends of the period were too strong of a force, and a culture of encounters and collaborations between Sephardic and Protestant scholars emerged out of this climate of toleration in Amsterdam.

One of the most well-known Jews among Christians in seventeenth-century Amsterdam was the Sephardic Rabbi, Menasseh ben Israel, whose highly active intellectual life reveals the

\footnotetext{
${ }^{44}$ In June of 1663, English traveler Philip Skippon visited the Dutch Republic. He commented that it was challenging to distinguish Iberian Jews from the Dutch, but that he was impressed with their presence in the Exchange. So much so that he estimated the number of Jews in the city to be 20,000, almost ten times the actual size. Kaplan, 2002, p. 639
} 
parallel interests of Jewish and Christian scholars during the period. Menasseh was a complicated figure; his parents had left their crypto-Jewish lives in Portugal before the Rabbi was born, and though it was common for Dutch Sephardic scholars to correspond regularly with their Christian contemporaries, Menasseh's involvement was uniquely high, and included a close friendship with Rembrandt, who provided a famous portrait of the rabbi (figure 6). His correspondences and publications were varied, both in audience and language, and commented on a range of philosophical and theological topics. The rabbi had an impressive ability to sit at the center of controversy, and turn a tensioned dialogue between conflicting religious doctrines into a peaceful and instructional discussion. His legacy lies in his connection to several popular movements that defined Protestantism in the early to mid-seventeenth century, including the study of the Hebrew language, millenarianism, and a consuming interest in the ten lost tribes of Israel. $^{45}$

These movements were especially popular in England, in particular the millenarians, who were concerned with an interpretation of the Book of Revelation which argued that the signs of the apocalypse had already begun and the 'End of Days' was imminent, which traditionally involved the conversion of all Jews at the return of Christ, the Christian Messiah. ${ }^{46}$ However, the messianic fever of the period was not limited to Protestant denominations, as Menasseh and his

\footnotetext{
${ }^{45}$ Menasseh's most famous work, The Hope of Israel, published in 1650 in Spanish, Latin, Hebrew, English, and Dutch, was on the Lost Tribes of Israel. In 1644, Menasseh recorded an official record from a Portuguese converso explorer, Antonio de Montezinos, who claimed to have encountered a Jewish Indian tribe in the Andes. The claim that the natives of the recently discovered Americas were Jews of the Ten Tribes of Israel, was a way to give these mysterious populations biblical context. For a short summary on the topic, see Popkin, Richard H. "The Rise and Fall of the Jewish Indian Theory." In Menasseh Ben Israel and His World, edited by Yosef Kaplan, Henry Méchoulan, and Richard H. Popkin, 63-82. Leiden: EJ Brill, 1989.

${ }^{46}$ For more see, Zakai, Avihu. "Thomas Brightman and English Apocalyptic Tradition." In Menasseh Ben Israel and His World, 31-44, 1989; and Katz, David. Philo-Semitism and the Readmission of the Jews to England, 16031655. Oxford; New York: Clarendon Press; Oxford University Press, 1982.
} 
fellow Jews, including the radical Spinoza, also trusted in the forthcoming Messiah. ${ }^{47}$ Menasseh ben Israel, in his ability to cross boundaries in theological discussion, insisted to both Jewish and Christian audiences that the encounter between Jews and Non-Jews was critical to the coming age, when an allegiance would be formed that neither group could deny, and only those who did not harm the Jews would be received by the Messiah. ${ }^{48}$ For English Puritans, the reign of Elizabeth I and the Reformed Church of England provided evidence of England as the location where the drama of the Last Days would unfold, and as their predicted date of the messianic age quickly approached, they became increasingly troubled by England's lack of a Jewish population. It was to Menasseh ben Israel that these troubled millenarians reached out, and together, an initiative promoting the return of Jews to England began. Sympathetic to this cause was English military and political leader, Oliver Cromwell, who in the mid-seventeenth century following the English Civil war and the deposition of King Charles I, became Lord Protector of the Commonwealth of England.

So it is during this short, yet significant period in English history - that of the six years of the Commonwealth, before the Restoration under Charles II - that we find our small Portuguese Jewish community living within the London parish of St. Katherine Creechurch. The tides of history that carried them to London involved a complicated journey - through the after effects of the Reformation and religious wars, the trials of the Iberian Inquisitions, the growth of mercantilism and the Dutch trade empire, and the intricate network of the Nación. After centuries of conflict, the West was no longer united in Christendom, but instead a diverse landscape of

\footnotetext{
${ }^{47}$ Between 1648 and 1666, there was a popular movement within Judaism known as Sabbateanism. Sabbateans, which included a large portion of the Jewish world, followed the teachings of Sephardic Rabbi and kabbalist, Sabbatai Zevi, who claimed to be the long awaited Jewish Messiah. At the age of 40, in 1666, Zevi was forced to convert to Islam by the Ottoman sultan, which upset and disillusioned his many followers.

${ }^{48}$ Méchoulan, Henry. "Menasseh Ben Israel and the World of the Non-Jew." In Menasseh Ben Israel and His World, edited by Yosef Kaplan, Henry Méchoulan, and Richard Popkin, 83-97. Leiden: E.J. Brill, 1989. p. 89
} 
Christian beliefs. As Judaism had always been understood as inextricably linked to Christianity, it was at this moment that European Jews found opportunity to became part of mainstream western society, as simply another religious denomination living within a Protestant nation, where desire for peace and stability had forced a new level of religious toleration amongst its citizens. 


\section{3 \\ A Community Emerges: The Spanish and Portuguese Jews of Seventeenth Century London}

In the autumn of 1655, the well-known rabbi of the large Spanish and Portuguese congregation in Amsterdam, Menasseh ben Israel, made a trip to England. He was on a personal mission to secure safe locations for persecuted Jews to emigrate in the wake of the Iberian Inquisitions. The religious environment in England at that moment was favorable towards Jews; a popular movement of millenarianism glorified the Hebrew language and fully supported the concept of the readmission of Jews to the country. Oliver Cromwell, the Lord Protector of the Commonwealth, was partial to this view, which Menasseh hoped to use to his advantage in his petition for the Official Resettlement of Jews to England. The Rabbi made his mission, and his meetings with Cromwell, publically known. As a result, Cromwell gathered delegates at the Whitehall Conference in December of that year to discuss the question of Jewish settlement in England.

It is curious to consider what a figure like Antonio Ferdinando Carvajal, a wealthy merchant of the Canary Islands living in London, would have thought about these proceedings. Outwardly, he would appear as his name suggests, a Spanish Catholic, completely separate from the debates at Whitehall. However, he was known by another name, Abraham Israel Carvajal, a 
prominent member of a small community of conversos living secretly as Jews in London. ${ }^{49}$ At that moment Carvajal was also known to Cromwell, completely separate from and probably to a greater degree, than Menasseh ben Israel. Having provided intelligence to the English government during wars with the Dutch, Spanish and Portuguese, he was on favorable terms with Parliament, and appears to have received personal favors from Cromwell himself. ${ }^{50}$ It is unclear whether they were aware of Carvajal's Jewish heritage during this period, though they did come to his support in 1645 when denounced by an informer for not attending church. ${ }^{51}$ Whatever the case, he was not associated with Menasseh's mission in 1655. His thoughts of those proceedings will go unknown, but his actions provide insight into the motivations of the first Jewish community during the early modern period in England. Earlier that same year of the Whitehall Conference, Carvajal and his sons received Patents of Endenization from Cromwell, granting them the same rights as an English native, especially important to Carvajal's participation in England's global trade economy. That November, only days after Menasseh Ben Israel submitted his petition, Carvajal requested help from Cromwell in retrieving his large estate in the Canary Islands, which was now threatened by embargo and seizure from Spanish authorities due to England's war with Spain. For Carvajal, his interests lay in securing his position in England's trade markets, not with Menasseh's mission to make England a safe haven for Jews to practice their religion openly.

It would not be long before Antonio Ferdinando Carvajal, and the other members of the converso community of London would be associated with the Rabbi's mission. Their motivations for doing so however, would still lie in their commercial interests. Commercial and

\footnotetext{
${ }^{49}$ Barnett, Lionel D., ed. Bevis Marks Records: Being Contributions to the History of the Spanish and Portuguese Congregation of London. Oxford: University Press, 1940. p. 4

${ }^{50}$ Wolf, 1894 , p. $18-19$

${ }^{51}$ Wolf, 1894, p. 16
} 
colonial rivalry had caused the war to break out in 1654 between England and Spain. Orders under Cromwellian England stated that the property of Spanish merchants within the country was liable to seizure ${ }^{52}$ On March $13^{\text {th }}, 1656$, another merchant of the Spanish Canaries residing in London, Antonio Rodrigues Robles, was caught red-handed with both Spanish goods and Spanish currency. ${ }^{53}$ For the small group of Jews discreetly living in London, this would provide an opportunity to expose their presence in order to secure their commercial interests within England. It was at this moment, the $24^{\text {th }}$ of that same month, that the famous petition headed by Menasseh Ben Israel was received by Cromwell. ${ }^{54}$ The Humble Petition of the Hebrews at Present Residing in this citty of London was signed by Menasseh, along with the leading members of the converso community, including Carvajal, who in doing so, made their Jewish identity public knowledge for the first time. For the Robles case, which would continue for almost two months, the defense was that he was not a Spaniard, but a Jew of Portuguese decent and a member of this converso community. Others of the converso experience testified that their families had fled the Inquisition in Spain and Portugal and were forced to practice their religion in secrecy out of fear for their safety, in the same manner Robles had argued. No firm conclusion could be determined by the courts and the goods were returned; the Commission for the Admiralty and Navy stated that they "doe not finde any convicting evidence to cleare up either the Nation or Religion of the petitioner." ${ }^{, 55}$ The actions of the members of the small converso community show that in order to continue in their prosperous commercial activities, it was

\footnotetext{
${ }^{52}$ Cesarani, David. Port Jews: Jewish Communities in Cosmopolitan Maritime Trading Centres, 1550-1950. London; Portland: Frank Cass, 2002. p. 111

${ }^{53}$ Kagan, Richard. Atlantic Diasporas: Jews, Conversos, and Crypto-Jews in the Age of Mercantilism, 1500-1800. Baltimore: Johns Hopkins University Press, 2009. p. 50

${ }^{54}$ Katz, David. The Jews in the History of England, 1485-1850. Oxford; New York: Clarendon Press; Oxford University Press, 1994. p. 135

${ }_{55}^{5}$ Kagan, 2009, p. 51; cited from Woolf, Maurice. "Foreign Trade of London Jews in the Seventeenth Century." Transactions of the Jewish Historical Society of England 24 (1974): 38-58.
} 
beneficial to their economic position to be identified as Jews loyal to the English state, and no longer as Spanish Catholics.

These events mark the beginning of a Jewish community in England's public consciousness. The Whitehall conference began a theoretical discussion on the status of Jews in England; the Robles Affair, and the threat of being economically disenfranchised, made it clear that Jews were already present. It was the political and religious climate of the Commonwealth under Cromwell that provided Jews the opportunity to make their presence known and they used it to their advantage to set the groundwork to gain safety and security, which continued for future generations. The members of the Spanish and Portuguese community of London carefully crafted their place in the city, selecting the public spaces where their Jewish identity would be recognized to their benefit, while quietly creating private spaces where their congregation could fully embrace their Jewish customs without danger of violence or harassment. The evidence from the spaces they inhabited in the city, and the early building projects they took on, are a testament to their interests in securing a place for their community within English society.

Creating a community space for religious worship became one of the first priorities of the early congregation. Immediately following the Robles Affair and proceedings with Cromwell, Carvajal signed a 21-year lease on large home in Creechurch Lane for the purpose of a synagogue, across from St Katherine Creechurch (figure 7) very near his own residence on Leadenhall Street, and near the homes of others of the early congregation (figure 5). The lot contained two houses, the larger leased by Carvajal, the corner house still leased by a tenant of the parish of St Katherine Creechurch (figure 8). An entry in the parish account book from 1656 stating an amount "paid for warning the workman before the Court of Alderman that were 
Imployed in building the Jewes Synagogue," makes it clear that the parish authorities, as well as the Guildhall authorities, were completely aware of Carvajal's use of the property on Creechurch Lane. ${ }^{56}$ Even though no official announcement or law was made by Cromwell or his government regarding public practice of Jewish worship, Carvajal encountered no disputes while setting up the Creechurch Lane synagogue, perhaps due to his favorable position with Parliament and status as a respectable gentleman merchant in London. For a community who had, for generations, held services in the complete secrecy of their own homes, their first synagogue on Creechurch Lane was completely public knowledge.

The building was two stories, the worship space on the second floor with a residence on the ground level, occupied by lodgers of the synagogue community (figure 8 ). This included the first Rabbi, Moses Athias, a cousin and business associate of Carvajal from Hamburg. A description of the interior of the synagogue after the initial remodeling appears in a letter written in 1662 by Englishman John Greenhalgh, who described his visit and experience of the Jewish services he attended. He wrote that the synagogue was "like a Chapel, high built; for after the first door they go upstairs into it." ${ }^{, 57}$ According to the plans meticulously reconstructed from evidence found in various documents, and published in Samuel's exhaustive study of the Creechurch Lane synagogue, one entered from a simple doorway in the center of the North side of the building (figure 8). According to Greenhalgh, the synagogue was considered a private space for the congregation, "though they did scarce admit of any [visitors], their Synagogue being strictly kept with three doors one beyond another."58 The existence of Carvajal's community may have been public knowledge, but they continued their religious practices discreetly. The stairway could be found at the end of the short entrance passageway, leading

\footnotetext{
${ }^{56}$ Samuel, 1924, p. 21

${ }^{57}$ Samuel, 1924, p. 51

${ }^{58}$ Samuel, 1924, p. 50
} 
upstairs to the main worship space. Greenhalgh described the traditional arrangement and ritual furniture: "the seats are not as ours, but two long running seats on either side, as in a school...on the midst of the floor, stood wheron the Service and Law were read, being like a high short table, with steps to it on one side as an alter...At the east end of the Synagogue standeth a closet like a very high cupboard, which they call the ark." ${ }^{, 59}$ The interior of the home had been repurposed into a traditional Sephardic worship space. The reading table described by Greenhalgh, was the bimah, the primary focus and principle influence on a synagogue's design. It customarily sits within the main axis of the building, as it did in Creechurch Lane, and towards the west side of the central aisle in Sephardic tradition. ${ }^{60}$ According to the plan, the bimah was placed more towards the center, likely due to the small space and need to fit other seating and furniture (figure 8). The bimah was traditionally raised on a platform with a railing enclosing it, as fitting to Greenhalgh's description. From here was where the officiant read from the Torah, as the other members of the community sat facing the bimah, in seats running parallel to the length of the building. Placed in the east end of the central aisle was the ark, the holiest feature of the synagogue where the Torah scrolls were kept. The worshipper's attention then moved from east to west, between the ark and the bimah, while seated facing each other and reading from their prayer books. This arrangement of seats was typical, the exchange of glances and gestures across the room, and division of attention created a sense of unity - placing importance on all parts of the space, all people, and all activities within. ${ }^{61}$

Our keen observer, Greenhalgh, also makes note of the separation between men and women during the services, a traditional practice in Judaism during the period. Commenting on a

\footnotetext{
${ }^{59}$ Samuel, 1924, p. 50-52

${ }^{60}$ Krinsky, Carol Herselle. Synagogues of Europe: Architecture, History, Meaning. New York: Architectural History Foundation, 1985. p. 22

${ }^{61}$ Krinsky, 1985, p. 22
} 
young boy during the service, "he got the inner door open and went to his mother...on one side of the synagogue there is a low, long and narrow latticed window, through which the women sitting in the next room, do hear." ${ }^{, 2}$ Greenhalgh was welcomed to the services by a Jewish associate, who sat with him. He was unmolested by the worshipping community, but perhaps due to feeling like an outsider witnessing foreign practices, was incredibly observant of the individuals sharing the space. As the young boy opened the door to the women's chamber, Greenhalgh noted that he "saw some of their wives in their rich silks bedaubed with broad gold lace, with muffs in one hand and books in the other. ${ }^{, 63}$ He also noted the men, all of whom wore traditional costume described as "hats covered with veils," which did not restrict his observation that "they were all gentlemen (merchants); most of them rich in apparel, divers with jewels glittering (for they are the richest jewelers of any)... and look as if strong intellectuals; several of them are comely, gallant, proper gentlemen. I knew many of them when I saw them daily on the exchange and the Priest there too, who was also a merchant." 64 The very early community of Carvajal and his handful of associates had considerable financial capital, all being successful merchant traders, owning ships and exploiting their global connections across the Sephardic Nación. The moment the synagogue was set up in 1656, the relatives and business connections of the three leading members, Antonio Ferdanando Carvajal, Domingo Vaez de Brito (Abraham Israel de Brito), and Antonio de Porte (Abraham do Porto), began to arrive in London, lodging within the same neighborhood and steadily increasing the population of the Sephardic community. ${ }^{65}$ As the congregation grew, the proportion of highly wealthy Jews lessened,

\footnotetext{
${ }^{62}$ Samuel, 1924, p. 52

${ }^{63}$ Samuel, 1924 , p. 52

${ }^{64}$ Samuel, 1924 , p. $56-57$

${ }^{65}$ Samuel, 1924
} 
however, the London public continued to view the entire community as gentlemen merchants of London's upper-middle class.

The neighborhood where these Jews called home was unique from any other Jewish settlement in Europe at that moment. Menasseh ben Israel had left England in 1657, disappointed in the results of his petition; he wanted a public declaration and written legal status that guaranteed tolerance and rights for the Jews of England. Instead they received a verbal agreement from Cromwell that Jews could live and practice their religion in England undisturbed. ${ }^{66}$ The only legislation regarding Jews dated back to before their expulsion in 1290 , and the results of the Whitehall convention only determined that, "There was no law which forbade the Jews returning to England."67 They were a people without a defined legal status, which in this case, worked to the benefit of the growing Jewish community. On the continent, Jews generally settled under a legal status that granted protection, but limited their rights within the Christian society. Outside of Amsterdam, it was common for Jewish communities to live within established ghettos, where Jews were restricted to a designated area and had judicial autonomy within their own community. The physical boundaries of ghettoization further isolated Jews from mainstream Christian society, and made assimilation during the modern period incredibly challenging for many Jews in Central and Eastern Europe. The atypical legal status of English Jews in the early modern period meant that no form of ghettoization was ever introduced in the country, nor were their legal rights specifically defined. Instead, they lived where they

\footnotetext{
${ }^{66}$ This verbal agreement between Cromwell and Carvajal is convincing enough to be stated as fact in current scholarship. However, it bothers me that the evidence for this claim is very weak, and though I'm not ready to refute it, it seems almost equally likely, that given the political climate in London, Carvajal proceeded under the context that no one told him no. Potentially an ask for forgiveness instead of permission scenario, but who knows.

${ }^{67}$ Wolf, Lucien. "Status of the Jews in England after the Re-Settlement." Transactions of the Jewish Historical Society of England 4 (1899): p. 178-179
} 
liked, mainly within walking distance of their synagogue where they worshipped regularly and had, for the most part, the same freedoms as natives. ${ }^{68}$ They mixed freely with Christians in the city, just as before 1656, making assimilation into English society a relatively effortless process. ${ }^{69}$ The first immigrants of the community required endenization, which they often received, to gain the rights of an English native, however, their children born in London were automatically citizens, with full rights to own property and participate in the English market economy.

The Sephardic Jews settled within the walls of the city, a majority living in the adjacent parishes of St James, Duke's Place and St. Katherine Creechurch (figure 4). By that point, the parish of St. Katherine Creechurch had been home to both foreigners and heretics for some time, so the Spanish Portuguese Jews who had prior to 1656 been converso foreigners, comfortably settled in this area of the city. ${ }^{70}$ It was a prosperous neighborhood, much of the congregation lived in substantial mansion homes around Creechurch Lane: Carvajal on Leadenhall Street, others on Creechurch Lane itself, Fenchurch Street, Great St. Helen's, St. Mary Axe, Bevis Marks, and within Duke's Place, which included Antonio Robles (figure 5). Leading into Duke's Place and directly across from the Creechurch Lane synagogue was a prominent city landmark known as the Great Gate (figure 9). Built by Augustinian friars in 1280, the Great Gate became well known from the late-seventeenth and into the eighteenth century as the entrance to the center of London's Jewish community. ${ }^{71}$

\footnotetext{
${ }^{68}$ Jews still could not be a member of Parliament, as they were unable to swear into office on the Holy Bible. Jewish Emancipation in England was official in 1858 and throughout Western Europe this occurred gradually between the late $18^{\text {th }}$ and $20^{\text {th }}$ centuries.

${ }^{69}$ For detailed account of Jewish assimilation into English society in the $18^{\text {th }}$ century, see Endelman, Todd. Radical Assimilation in English Jewish History, 1656-1945. Bloomington: Indiana University Press, 1990.

${ }^{70}$ Wolf, Lucien. 1893. "Crypto-Jews Under The Commonwealth.” Transactions of the Jewish Historical Society of England 1: p. 56

${ }^{71}$ Samuel, 1924, p. 8
} 
Kinship and community were defining factors of this settlement of Jews in England, before and after 1656. Before the establishment of Creechurch Lane, while the public believed them to be a small minority of Roman Catholics who prayed at the Spanish Embassy, they likely practiced Jewish ritual together in the home of Carvajal. ${ }^{72}$ New arrivals to the expanding community also lived together; it was customary to take in lodgers and help them get settled in the city. Many leading members had homes large enough to take in family and business relations who had recently moved to England. The residence of the ground floor of the synagogue had a variety of tenants associated with the congregation over the years, from the Rabbi Athias, to Hebrew tutors and others needing lodging upon arrival. ${ }^{73}$ There was also a home, owned by a plumber, Mr. Linger of the St Katherine Creechurch parish, on the corner of Creechurch Lane and Leadenhall Street that served the purpose of a hostel for unattached Jews new to London. The Jewish associate of John Greenhalgh also invited him to a Purim feast and a Passover Seder held at this lodging house, which he declined. ${ }^{74}$ Taking in guests, or assisting them with their accommodations was extremely common within the congregation. This practice makes Menasseh Ben Israel's choice of residence in the Strand, far from London's converso population, especially telling. Other than the moment in the spring of 1656 when their concerns overlapped, the Dutch rabbi seemed to have almost no contact with the early congregation, and even turned to Cromwell for financial assistance in 1657, pleading that he was "in this land of strangers.",75 The motivations of the tightly knit Jewish community of London appear to be separate from those of Menasseh ben Israel of Amsterdam; they were completely satisfied without a public declaration of tolerance from the English government, as long as their financial interests

\footnotetext{
${ }^{72}$ Katz, 1982, p. 3

${ }^{73}$ Samuel, 1924

${ }^{74}$ Samuel, 1924 , p. 56

${ }^{75}$ Katz, 1994, p. 139
} 
remained secure. Significantly, they established their community at Creechurch Lane with little guidance from the famous Dutch rabbi.

The growing congregation may not have been particularly interested in associating with Menasseh ben Israel, but they did have strong ties to the Amsterdam Spanish and Portuguese community, as well as to Hamburg and other centers across the Atlantic connected by the Nación where Sephardic Jews had settled in the wake of the Inquisition. Like Robles and Carvajal, many of the members of the growing London congregation made their livelihood from global trade. They emigrated from Spain, Portugal, Holland, Germany, Flanders, and France; most from wellestablished and prosperous families who had for generations been involved in mercantile practices. ${ }^{76}$ England, which had a growing international trade economy as well as trends towards religious toleration, must have looked like an ideal settlement for these Jewish families. The Spanish and Portuguese Jewish merchants were importers and exporters of a wide variety of commodities, and in the mid to late seventeenth century, they dominated London's trade in minted and unminted bullion, as well as diamonds and jewelry (as mentioned by Greenhalgh earlier). ${ }^{77}$ Their commercial connections were especially strong with Barbados, Jamaica, Spain, Portugal, and Amsterdam - all centers of Sephardic settlements of the Nación. ${ }^{78}$ Amsterdam in particular was at its height in prosperity and many of London's Jewish merchants had relations and business connections with their mother congregation. With this global trade network firmly in place, the London congregation did very well for itself financially. In 1663, thirty Jews had

\footnotetext{
${ }^{76}$ Woolf, Maurice. 1974. "Foreign Trade of London Jews in the Seventeenth Century." Transactions of the Jewish Historical Society of England 24: p. 48

${ }_{77}^{7}$ Diamond, A.S. 1974. "The Community of the Resettlement, 1656-1684." Transactions of the Jewish Historical Society of England 24: 134-150.

${ }^{78}$ Diamond, 1974, p. 134
} 
large accounts with the goldsmith-banker Alderman Edward Blackwell, and by 1672 the number had risen to seventy-seven. ${ }^{79}$

It is no coincidence that the London Jewish community surfaced at the same time that England's Navigation Acts appeared. The series of laws favored English merchants and were intended to regulate commerce between England and its colonies. This was the age of mercantilism, when practices of the governments of Western Europe centered on policies that benefitted the economic interest of the state, regardless of existing law, privilege, tradition, as well as religion. ${ }^{80}$ This was a major shift from the medieval focus on the entirety of 'Christendom' and a move towards nationalism and secularization of government. The economic principles of mercantilist practice, though never specifically articulated, centered on the existence of a finite volume of world trade and the naturally following implication - that gain for one country had to be at the expense of another. As seen from the Robles Affair, it was important for the Jews of London to be viewed as supporting the English state if they wanted to continue in their occupations. To work around the Navigation Acts, the foreign born Sephardic Jews only had to apply for endenization - between 1655 and 1680 over ninety members of the Creechurch Lane synagogue gained naturalization through this route. ${ }^{81}$

Not everyone welcomed the success that the Spanish and Portuguese Jewish merchants found on the Royal Exchange and in the ports of London. By the 1680's, English merchants had emerged as a dominant power in the global trade economy, and their Jewish neighbors now represented significant competition. Between 1660 and 1680, a variety of petitions against Jewish merchants were submitted to local, provincial and national authorities, all questioning

\footnotetext{
${ }^{79}$ Woolf, 1974, p. 48

${ }^{80}$ Israel, 1989, p. 2

${ }^{81}$ Kagan, 2009, p. 54; Also, Ross, J.M. 1974. "Naturalisation of Jews in England." Transactions of the Jewish Historical Society of England 24: p. 62
} 
their right to trade in England on equal standing as native English merchants. ${ }^{82}$ These denunciations usually came after a new authority rose to power. Following the rise of Charles II, the Jews petitioned the king directly in1664, stating that they were "dayly threatned by some with the seizure of all their estates \& are told that both their lives and Estates are forfeited to your Majestie by the Lawes of your Kingdom." ${ }^{83}$ For the first time in this period of Jewish history in England, the Jewish community received a written statement of protection; the response from Whitehall was in their favor, assuring them that no one would be permitted to molest them, and that "they may promise themselves the effects of the same favor as formerly they have had, soe long as they demeane themselves peaceably \& quietly with due obedience to his Majesties Lawes \& without scandal to his Government." ${ }^{, 84}$ It was this statement that kept visitors to their synagogue, like Greenhalgh, to a minimum, unlike their mother synagogue in Amsterdam, which was well known for their regular Christian guests. In Falmouth, Jamaica in 1680, a Royal customs agent accused Jewish merchants of attempting to cheat the crown when he discovered that a ship captained by an English Quaker carried goods from thirty-five different traders, all Jews. His attempt to condemn their goods under the Navigation Acts, and claim that Jewish merchants were not entitled to conduct trade in English colonies, was overthrown by the fact that the Jews in question had been granted Patents of Endenization from the crown. ${ }^{85}$ What caused the customs agent to initially suspect the goods was the fact that the ship had the final destination of Amsterdam, and even though the case was settled in favor of the Jews of London, it demonstrates the careful line these merchants played in their business dealings. Whatever the situation, whether they were acting in adherence to the Laws of England or not, they certainly

\footnotetext{
${ }^{82}$ Kagan, 2009, p. 54

${ }^{83}$ Gaster, 1901, p. 4

${ }^{84}$ This reference to "the same favor as formerly they have had" is the existing evidence for the verbal agreement between Cromwell and Carvajal. Gaster, 1901, p. 4-5

${ }^{85}$ Kagan, 2009, p. 54-56
} 
used their secure position in the country to the benefit of their commercial interests. As James II ascended the throne in 1685, further denunciations came from competing English merchants who demanded Jews to be taken off the Exchange and forced to pay fines for their religious transgressions. ${ }^{86}$ Again, the Jews petitioned directly to the king and received similar favors, the denouncers instead were reprimanded for unnecessary disruption of peace in the city. This would be the last time it was necessary to defend their commercial activities; after 1685 no further accusations against the Jews of London were brought to the courts.

As the country remained favorable to both their economic and religious practices, the Spanish and Portuguese Jewish community in London steadily grew from the 1650's to the end of the seventeenth century. What had begun as a small community of around 20 families in 1657 had expanded to a congregation of 414 members in $1684 .{ }^{87}$ During this period of growth, their synagogue on Creechurch Lane underwent a large scale remodeling project. In 1674, the Jewish congregation took over the lease of the adjacent corner house, and expanded their worship space by combining the two homes (figure 10). ${ }^{88}$ From the main entrance on Creechurch Lane, worshipers now passed through an impressive covered porch, which included a pair of benches and lamps, leading to "Hansome and Workmanlike" double doors, above which was an ornamental pediment, "all in the best traditions of seventeenth century architecture." ${ }^{\prime 89}$ Beyond the entrance sat a wide staircase, leading up into the main worship space. The interior of the remodeled synagogue must have been a remarkable sight, as a French traveler noted that "The

\footnotetext{
${ }^{86}$ Katz, David. "The Marginalization of Early Modern Anglo-Jewish History." In The Jewish Heritage in British History: Englishness and Jewishness, edited by Tony Kushner, 60-77. London: Frank Cass, 1992. p. 69-73

${ }^{87}$ Barnett, 1940, p. 23

${ }^{88}$ Samuel, 1924 , p. $42-43$

${ }^{89}$ Samuel, 1924 , p. 45
} 
best of the seven [synagogues in Venice] is not near so fine as that in London. ${ }^{, 90}$ What they would have encountered was a large, double height space, with galleries supported by Doric columns and arches. The columns continued into the gallery level, also ending in arches supporting the coved ceiling above. The ceilings under the galleries were also coved, and the interior was paneled throughout. Women of the congregation had a separate entrance on the eastern side of the building, and stairway leading to the north and south galleries, which were enclosed, likely by a latticed screen (figure 10). The west gallery provided additional seating for men, as it was open to the main space below and connected directly, via an additional staircase. The synagogue's main floor had increased by about 350 square feet from its previous dimensions, allowing space for the bimah to move away from the center, and towards the west end as in Sephardic custom. The newly remodeled synagogue of the wealthy Sephardic community became an admired architectural site in London. A map based on a seventeenth century survey by Thomas Jeffereys, not published until it was outdated in 1753, even included the "Jews Synagogue" on Creechurch Lane as one of London's places of interest (figure 11). ${ }^{91}$

By the end of the seventeenth century, the Jewish community of London was a wellestablished part of the city. Their right to participate in England's trade economy and even act as commodity brokers on the Royal Exchange had been secured by a government that allowed them to go about their business unmolested. ${ }^{92}$ The protestations against their mercantile practices from competing English merchants never turned violent, and beyond that, rarely questioned their right to reside in the country. These complaints were often only about the amount Jews should pay to

\footnotetext{
${ }^{90}$ Quoted in Samuel, 1924, p. 45 from an English translation of F.M. Mission's "Nouveau Voyage d'Italie"

${ }^{91}$ It should be noted however, that this is a rare map; the majority of maps from before Bevis Marks do not include the Creechurch Lane Synagogue or the presence of Jews in London. Samuel, 1924, p. 42

${ }^{92}$ In 1697, the City of London imposed a cap on the number of Jewish commodity brokers, 12 out of 124, which was part of a general reform of the Exchange. This did not limit the number of Jewish stockbrokers, who did business elsewhere, only the number of commodity brokers officially sworn into office. Endelman, 2002, p. 36
} 
customs. The community was dedicated to keeping a quiet front and attempted to avoid any scandal from occurring both outside or within the congregation. Compared to their brethren in Amsterdam and Hamburg, the London community allowed for a much broader definition of what it meant to be a member of the congregation. London's Jewish community had been founded completely by conversos, a population who had never experienced public Jewish life. This is notably distinct from other communities of the Sephardim, like Amsterdam, which was characterized by generations of Jewish families openly practicing their faith and leading rich, open intellectual, artistic, and religious lives as Jews. The converso Jews of London instead had always been forced to assimilate with their surrounding culture, many of their families had been practicing Catholics, and had strayed quite far from the orthodoxy of Judaism. As conversos, The members of the London congregation were descendants of the first group of European Jews to have the most extensive and direct personal and religious experiences outside the Jewish community. In terms of language, dress, and tastes, they were no different from their Christian neighbors, and being nominally Catholic, even had access to university education in a period when Jews were barred from this privilege. ${ }^{93}$ What this meant for the London congregation was that even after Creechurch Lane opened, some members were not interested in shedding their Catholic public image, and others refused to accept the orthodox version of their religion and the laws of the synagogue. ${ }^{94}$ In Amsterdam, these members would have certainly been excommunicated, but in London, there was a stronger interest in maintaining ties with these factions. Excommunications would have potentially caused public scandal, and the appearance of a quarreling community would have damaged their carefully cultivated public image as upstanding London residents. Further, their livelihoods depended on their business connections

\footnotetext{
${ }^{93}$ Endelman, 2002, p. 35

${ }^{94}$ Kaplan, Yosef. "The Jewish Profile of the Spanish-Portuguese Community of London During the 17th Century." In An Alternative Path to Modernity. Leiden; Boston; Koln: Brill, 2000.
} 
with others in the Nación, and breaking these ties would not have been to the community's benefit.

The congregation's dedication to keeping themselves unified and their presence discreet may have added to the community's relatively effortless integration into city life in London. The early complaints against their commercial practices stood apart from other experiences within the city, as a generally tolerant religious climate had already been in place. In this context the Creechurch Lane synagogue opened and services were held without issue. By the midseventeenth century, English officials referred to Jews casually in state documents, as if their presence in London was not even slightly irregular. ${ }^{95}$ We have already seen the tolerant actions of the synagogue's neighbor, St. Katherine Creechurch, who celebrated the life of the synagogue founder and one of their highest tithe-payers, Antonio Ferdinando Carvajal, with the ringing of their Great Bell on his death in 1659. ${ }^{96}$ The public's comfort with the presence of Jews is further shown after the Great Fire in 1666, when the population of London, in search of a scapegoat, turned on anyone perceived as alien in the city. No accusations or harassment against any member of London's Jewish community occurred at this moment, suggesting that they were thoroughly familiar to the general public and well established residents. ${ }^{97}$ By 1701 and the opening of their grand purpose built synagogue, Bevis Marks, the Spanish and Portuguese Jewish community had firmly established their place in the city of London, and had marked their neighborhood with the public landmark of their first house of worship at Creechurch Lane.

\footnotetext{
${ }^{95}$ Occurred with regards to the Jew Simon de Caceres in records from 1655-6; Katz, 1982, p. 235

${ }^{96}$ Samuel, 1924, p. 20

${ }^{97}$ Samuel, 1924, p. $40-41$
} 


\section{4 \\ Bevis Marks Synagogue: The Architecture of an \\ English-Jewish Congregation}

By the end of the seventeenth century, our Spanish and Portuguese Jewish congregation was well established in the city of London. The petitions of the preceding decades against their commercial practices and religious transgressions had come and gone without disturbance to their growing community. Those born outside of England continued to gain naturalization through Patents of Endenization from the crown, and the Jew's undefined legal status kept their community as a whole from being defined as 'alien.' At that moment, London was already home to a wide range of Christian denominations, and the Jewish community fit into the city's varied religious landscape. They were still unable to hold positions in Parliament, being unable to swear into office on the Holy Bible, however, dispensations had been allowed to let them practice as commodity brokers on the Royal Exchange, and in the year 1700, one Solomon de Medina, a Dutch Jew of converso origins, became the first professing Jew to be knighted in England. ${ }^{98}$ The Sephardic congregation had already constructed an architectural landmark in London. Their synagogue in the repurposed home on Creechurch Lane, with its interior remodeled in the style of popular architectural trends in England, was a symbol of the community's status in the city. In the final decade of the century, the London Sephardic congregation faced several challenges that

${ }^{98}$ Israel, 1985, p. 130 
demonstrate both the growing confidence of their English-Jewish identity, as well as their commitment to the values of the previous generation, the synagogue founders, who had set the foundation of their secured status. This would culminate in the construction of their celebrated synagogue at Bevis Marks, whose opening in 1701 ushered in a new era for English Jews (figure 12).

Major changes within English politics continued to make the synagogue's ruling body anxious over their community's legal status, and the Glorious Revolution of 1688 that brought the Protestants William and Mary to the throne of England was no exception to this trend. In an attempt to tap into the supposed wealth of the London Sephardic Jews, a bill was proposed to the House of Commons on November 7, 1689, recommending the Jewish community be taxed a total sum of $£ 100,000 .{ }^{99}$ The council within the synagogue quickly took action, using every legal procedure and private interest at their disposal to protest this proposed legislation. After an expensive four-month battle, the synagogue won, and the bill died before any law was enacted. ${ }^{100}$ In 1690 however, the poll tax was fixed and Parliament charged Endenizened Jews at a higher rate than other foreign merchants, a change that was eliminated in subsequent years. ${ }^{101}$ England was facing a financial crisis due to a lack of currency within the nation, and after two years of investigating the subject, a committee of the Commons reported in 1690 that Jews were responsible for exporting large quantities of silver out of England, since they "would do anything for a profit." ${ }^{\prime 102}$ The synagogue leaders immediately came to the defense of their community by enacting several laws within the congregation that they hoped would prevent further gossip. Between 1689 and 1696 synagogue ordinances were passed that forbade congregation members

\footnotetext{
${ }^{99}$ Barnett, 1940, p. 21

${ }^{100}$ Cost to the synagogue was $£ 93.8$ s. 9d.; Barnett, 1940, p. 21

${ }^{101}$ Endelman, 2002, p. 36

102 Barnett, 1940, p. 22
} 
from exporting silver and gold, and indicated certain periods when Jews could not be present during any coinage sales made in public. ${ }^{103}$ It is hard to know how strictly the congregation followed these measures, but they do show a continued effort towards avoiding conflict and maintaining the community's high reputation in the public eye.

While the synagogue elders worked to preserve the discretion of the earlier generation, the number of congregation members continued to steadily rise, and with it, the synagogue's financial capital. Their space at Creechurch Lane became inadequate for the growing community, and in early 1694, plans for expanding once again were discussed, to the point that the Churchwardens at St. Katherine Creechurch appointed a committee to assist in the project. ${ }^{104}$ This plan was soon replaced with a more confident one, in which the congregation would build a brand new and far more impressive synagogue in the city of London. The community began contributing large sums towards the construction of their new worship space, and a nearby site was found - the open plot known as Plough Yard (figure 5). Plough Yard and the properties adjacent were owned by the speaker of the House of Commons, Sir Thomas Littleton, who provided the congregation with a 99-year lease for the site, finalized in November of $1699 .{ }^{105}$ Several members of Spanish and Portuguese Jewish community were already renting parts of the property for their personal use; there were a handful of stables, a garden, and small shops on the site. The synagogue itself was also paying rent to Littleton, the community's Kosher butcher shop could be found in Plough Yard, an important establishment that marked the area as a Jewish neighborhood. The lease was communicated through an intermediary, but the names of Antonio Gomes Serra, Menasseh Mendes, Alphonso Rodriguez, Manuel Nunes Miranda, Andres Lopes and Pantaleao Rodregues of the Creechurch Lane congregation appear as leaseholders for the

\footnotetext{
${ }^{103}$ Barnett, 1940, p. 22

${ }^{104}$ Barnett, 1940, p. 23-24

${ }^{105}$ Gaster, 1901, p. 61-62
} 
whole of the property. According to the document, these men had the "Liberty, power and authority" to demolish any existing structures and build anywhere on the site which was bounded by the streets Bevis Marks and Heaneage Lane. ${ }^{106}$

The synagogue's design had been under discussion in the years leading up to the finalization of the lease on the property. Records from the congregation show two payments made in 1694 to a joiner, Henry Ramsay, for making 'un modelo pa una Esnoga,' though the author of the designs, the form of the models, and whether they were meant for a remodeled or purpose-built space, are sadly lost to time. ${ }^{107}$ In February of 1699 , before the synagogue council had concluded communications over the Plough Yard property, a 'Building Agreement' was signed between the same men, Antonio Gomes Serra, Menasseh Mendes, Alphonso Rodriguez, Manuel Nunes Miranda, Andres Lopes and Pantaleao Rodregues, and a "citizen and merchant taylor of London," Joseph Avis. ${ }^{108}$ Avis was a Quaker carpenter, as well as entrepreneur and contractor, who had previously worked on prominent projects for both Christopher Wren and Robert Hooke, the leading architects of late seventeenth-century London. These projects would have made him highly familiar with the most current trends in English religious architecture, and an ideal candidate to lead the construction of a new synagogue for a Jewish congregation keen to maintain their status as respectable, yet reserved, residents of London. His experience included work as a carpenter and joiner for Wren's St. Bride's Fleet Street (1680) and St. James, Piccadilly (1683), as well as with Hooke on an entry way at Merchant Taylor's Hall (figure 13, figure 14, figure 15). ${ }^{109}$ To the construction at Bevis Marks, Avis brought a team of English

\footnotetext{
${ }^{106}$ Indenture of 1699 reproduced in Gaster, 1901, p. 62-64

${ }^{107}$ Records show a 'Mr Ransey,' identified as Henry Ramsay in the Guildhall records in Samuel, 1924

${ }^{108}$ Gaster, 1901, p. 68

${ }^{109}$ Wren, Christopher. “The Parochial Churches of Sir Christopher Wren, 1666-1718.” In Publications, v. 9-10, edited by Arthur T Bolton and H Duncan Hendry. Oxford: Printed for the Wren Society at the University Press, 1932. p. 126
} 
craftsmen, all of whom had worked on Wren city churches in the wake of the Great Fire of 1666. The group included, in particular, one John Sims, who had worked as a principal joiner at the Wren city churches of St. Clement Danes in the Strand (1682) and St. Bride's, Fleet Street (1680), and another, Thomas Clark, who had been the synagogue's principal carpenter during the remodeling at Creechurch Lane in $1674 .{ }^{110}$

If the design of the synagogue at Bevis Marks had an individual author, the remaining records do not document this fact. The final form, still extant in London today, together with the existing evidence, argues in favor of a project not designed by an individual, but a combination of cultural connections with both London and Amsterdam, precedent in Sephardic worship space, and financial capital of a congregation capable of hiring skilled, experienced English craftsmen. As capable as Avis was to design the synagogue's form on his own, the records reveal a large involvement of the Sephardic congregation in the new construction, as well as the existence of an unidentified model. The construction details are defined in such a way that their intention is to guarantee the quality of the finished work and that the craftsmen hired by Avis would be provided appropriate pay for their services. Avis himself had a reputation as an upstanding citizen; it is strongly rumored that he returned the unused portion of the $£ 2,650$ budget, refusing to profit from constructing a House of God, although documentation for this claim is lacking. ${ }^{111}$ Possible witness of Avis's piousness matching that of the governing body of the orthodox synagogue is provided by a hand written addendum to the contract, stating that Avis would "hereby promise and agree neither he or his workmen or any others by his order shall

\footnotetext{
${ }^{110}$ Rubens, Kenneth. "Bevis Marks Synagogue and the City Churches." Transactions of the Jewish Historical Society of England 37 (2002): p. 126

${ }^{111}$ Kadish, 2001, p. 5, referenced from Gaster, 1901
} 
work on the new intended building... on any of the Jewish Festival days or Saturdays which shall happen in the time of [the building's construction]."112

The building agreement, which mentioned the model in several places, required the synagogue to "contain in length within the walls fourscore [80] foot and in breadth between the walls fifty foot and in height from the floor to the ceiling thirty-two foot." ${ }^{, 13}$ Other details described the columns to be of "yellow firr" with stone bases, "painted three times with oyle" to imitate the look of marble, and were to carry above "a true freece and cornisht and a brest panill with sherquer worke." The windows were to be glazed with "good English glass" with iron bars and "easements as shall be thought fit and convenient." The craftsmen were instructed to build "wainscott seaven foot high round the inside of the said new building" and make the "gallaryes and staircases as is described in the said modell." The front entrance was to be approached through a courtyard paved with "free stone," and to contain a "stone doorcase... six foot wide with three hansome stone steps," fitted with an oak doorway "twelve inches square." Further specifications listed in the agreement include the precise measurements, quality and type of building material for many other constructed features, such as roof beams, joists, window frames, floorboards, and benches. No mention of the Ark is found in the building agreement, though it was also built at this moment, and bears resemblance to Avis' prior project at the Merchant Taylor's Hall (figure 15, figure 16). Also listed was a condition that the craftsmen were responsible for "all other worke and workemanship whatsoever as well as named or not named or omitted that shall be needful and necessary to be done and performed for the compleating and finishing the said new intended large building." 114 The synagogue remains near

\footnotetext{
${ }^{112}$ Gaster, 1901, p. 72

${ }^{113}$ Gaster, 1901, p. 68

${ }^{114}$ Gaster, 1901, p. 69
} 
its original condition today, and in addition, a drawing authored by $\mathrm{M}$. Bellisario dating from the second half of the eighteenth century depicts the interior at an earlier date (figure 17).

The building contract, even with its many details, left room for small stylistic decisions to be determined by the craftsmen themselves, providing opportunity to showcase their prior experience from some of Wren's most noteworthy London city churches. However the synagogue form, as a type of religious architecture, is highly ritualized and any design would have required extensive involvement from the Jewish congregation's governing body. The traditional arrangements and rituals practiced within a synagogue are central to Judaism and are meant to directly connect a congregation with past generations of Jews, back to the original temple in Jerusalem. This inherent awareness of continuity would have led the London Sephardic Jews to look to both their own past and the broader Jewish community for design precedent. For the London congregation, their past spanned only a single generation, making their first official worship space at Creechurch Lane both a place of deep meaning for its members and an example for their purpose built synagogue at Bevis Marks. From a wider perspective, their mother synagogue in Amsterdam, where an architectural achievement had recently been completed, provided further connection and inspiration.

The community in Amsterdam, to which Menasseh ben Israel had been rabbi, was flourishing both economically and culturally during the seventeenth century, and their architecture reflected the confidence of the Dutch Jewish merchant class. In 1675, this community opened the doors of their own new synagogue, the grand Esnoga, a revolutionary moment in the history of synagogue design (figure 18). Compared to the London congregation who were practicing their religion openly, yet still discreetly at Creechurch Lane, the Esnoga was 
a grand monument, one of the largest and most imposing buildings in 1670's Amsterdam.

Designed by Christian architect Elias Bouman, this was the first time in European history that Jews had an opportunity to express themselves architecturally on such a grand scale. ${ }^{115}$ Built along a major canal, the Esnoga's architectural features borrowed from continental Protestant building forms, in particular, the Huguenot Temple at Charenton, built in 1622 (figure 19). The French Huguenot church, with its galleried, barrel-vaulted interior, became a prototype for many Dutch Protestant church forms, as well as the Esnoga (figure 20). ${ }^{116}$ The response to the Esnoga was positive both within the congregation and outside. The community continued in their practice of welcoming visitors to their services, now held in a worship space as grand as the Dutch Protestant churches elsewhere in the city of Amsterdam. The site became the subject of many artistic endeavors, including three oil paintings by Dutch painter Emanuel de Witte (figure 21). As the first synagogue to garner such a reception, it has been highly influential on Sephardic worship spaces throughout the Nación, including Bevis Marks.

During this same period however, English architecture was being shaped by another force: Christopher Wren and his large scale rebuilding of London parish churches following the Great Fire of 1666. Influenced by the writings of Vitruvius and Serlio, Wren looked to the Roman basilica form as inspiration for his city church plans. In the late 1670's he developed an innovation in the basilica plan, seen first at Christ Church, Newgate in 1677 (figure 22). ${ }^{117}$ It was here that Wren began playing with a two-storied basilica, with the gallery seamlessly blended into the design while still following the strict orders of Vitruvius. This scheme was seen again at

\footnotetext{
${ }^{115}$ Israel, 1985, p. 220

${ }^{116}$ Discussed in further detail in the next chapter of this thesis. The influence of the Charenton Temple on Dutch Protestant church design and the Esnoga is argued by Helen Rosenau and Kenneth Rubens in: Rosenau, Helen. "The Synagogue and Protestant Church Architecture." Journal of the Warburg and Courtauld Institutes 4, no. 1/2 (1940): 80 - 84.; Rubens, Kenneth. "Bevis Marks Synagogue and the City Churches." Transactions of the Jewish Historical Society of England 37 (2002): 117-31.

117 Summerson, John. Architecture in Britain, 1530-1830. Harmondsworth: Penguin Books, 1970. p 215-216
} 
St. Peter's Cornhill, also built in 1677 (figure 23), and again at St. Clement Danes, in 1680, with further variations in the vaulting and incorporation of the galleries (figure 24). Wren's twostoried basilica arrangement, now standardized to a five bay church plan, was used at St Bride's Fleet Street (figure 25), where major work was done by both Joseph Avis and John Sims, who would later work on Bevis Marks. ${ }^{118}$ Avis' familiarity with Wren's city church designs was further cemented at St. James Piccadilly, completed in 1683 (figure 26). For Wren, St. James Piccadilly was the culmination of his galleried basilica designs, and a model for parish churches to follow. In a letter written in 1711 to a friend on the Commission for Building Fifty New City Churches, Wren reflects on his city church designs and lists his planning guidelines. Included are recommendations for the site and size of a parish church. According to Wren, a church should be sited "as forward as possible into the larger or more open streets," where their porticoed fronts would be highly visible, and with their towers rising above, would provide appropriate "ornament to the town." ${ }^{119}$ A further key detail for church design was in its acoustic function; Wren's recommendation was that it should hold no more than 2000 people, having a main space with the approximate dimensions of 60 feet wide and 90 feet long. Any larger volume would "create Noise and Confusion," and interfere with the main function of a church, which was to hear the preacher. In the letter, Wren singled out St. James Piccadilly as the best model for parish church design, as it met his key criteria (figure 27). Wren's church planning, especially their gallery spaces, the attention paid to the east end altar and focus on the church's auditory function - blended seamlessly with the ritual needs of a Jewish worship space (figure 28). In a synagogue, emphasis was on the ark, placed in the east end, and the reading table, or bimah,

\footnotetext{
${ }^{118}$ Schless, Nancy Halverson. "Peter Harrison, the Touro Synagogue, and the Wren City Church." Winterthur Portfolio 8 (1973): 187-200. p. 194

${ }^{119}$ Wren, Christopher. "The Parochial Churches of Sir Christopher Wren, 1666-1718." In Publications, v. 9-10, edited by Arthur T Bolton and H Duncan Hendry. Oxford: Printed for the Wren Society at the University Press, 1932.
} 
towards to west end in Sephardic tradition. The galleries provided a separated worship space for women, and Wren's ideal dimensions would also benefit a synagogue, where being capable of hearing a reading from the Torah scrolls was an important part of the service.

The Spanish and Portuguese synagogue at Creechurch Lane had already incorporated some of the features found in Wren's basilican church forms in the 1674 remodel. The added north, south and west galleries that opened into the main worship space below were supported by Doric columns joined by arches, and repeated on the second level to support the coved nave ceiling, in a similar style to many of Wren's city church galleries, only with far simpler vaulting and ornament. The interiors of St. Clement Danes, along with several others contemporary to Creechurch Lane like, St. Bride's Fleet Street and St. James Piccadilly, combined with the completed interior of Bevis Marks, can perhaps give clues to both the interior aesthetic at Creechurch Lane, and the stylistic features that may have been brought into Bevis Marks (figure 24, figure 25, figure 26). Bevis Marks shares the Doric columns and wainscoting described at Creechurch Lane, figure 29, though it does not share the blended two-storied galleries as the remodeled synagogue did with the Wren city churches (figure 12). For the members of the tightly knit Jewish community, Creechurch Lane would have held significant meaning - not only was it the only synagogue in London, but for the many who had come from converso families, it was the only public house of worship they had ever known. Several benches in Bevis Marks do in fact come from this first synagogue, so they clearly were not adverse to merging the (relatively) old with the new (figure 29). From the comparisons already made with Creechurch Lane, it is clear the city churches re-built by Christopher Wren during this period also impacted the design at Bevis Marks, especially given the background of the craftsmen and the congregation's continued interest in an English identity. At the same time though, many of the 
leading members of the congregation were well travelled and likely familiar with the synagogues of their fellow Jews in the wider Sephardic diaspora, specifically Amsterdam and their grand Esnoga. The combination of both local and continental influences on the design of Bevis Marks can be observed through careful analysis of the synagogue's architectural features.

Beginning with the site, Bevis Marks was only a block away from Creechurch Lane, and still within the center of London's unofficial Jewish neighborhood (figure 5). Unlike Wren's city churches, whose site planning provided maximum public visibility, the Bevis Marks synagogue was built tucked away in a courtyard, hidden from the main thoroughfare (figure 30). Their lease on the property allowed them to build anywhere within its bounds, which included up to the major street Bevis Marks, however, the permission granted from the 'City Fathers' to construct a synagogue included the condition that it was not on a major route so as to not offend Christian residents. ${ }^{120}$ The result of this is a site plan that is in some ways comparable to that of their mother synagogue, the Esnoga in Amsterdam (figure 31). The Dutch Spanish and Portuguese synagogue sits within a courtyard, the main entrance to the worship space is from within the compound, not from the main road (figure 32). A likely source for this design, specifically of a temple situated within the walls of a complex, were the popular depictions of Solomon's Temple (figure 33). For a congregation interested in declaring its presence and the renewed confidence of the Jewish people of Western Europe, recalling the famed temple of their ancestors was an understandable choice given the popularity of the figure of King Solomon to both Jews and Christians of the period. The comparison of the Esnoga to Solomon's Temple was likely made

\footnotetext{
${ }^{120}$ This condition is mentioned in several sources, in the most detail in Kenneth Rubens' essay on Bevis Marks. However, I'm still unable to find the original source material, or to whom the 'City Fathers' refer. I'm unsure if this is a repeated myth regarding the synagogue's history or relevant information regarding the synagogue's construction.
} 
during its construction, as it was a rabbi from within their congregation, Jacob Judah Leon 'Templo,' who was well-known for taking his model of the Temple of Solomon on travelling public displays. ${ }^{121}$ Leon Templo's depiction of the historic temple was similar to past studies, which placed the main worship space within a walled complex, like that of the Amsterdam synagogue. A considerable difference between the siting of Bevis Marks and the Esnoga is in the temple's scale and visibility. While Bevis Marks could not been seen from the main street, its height masked by the surrounding buildings, the Esnoga was conceived on a much grander scale, and the intention was to create a monument that was publically visible. The Dutch synagogue towers above the courtyard it sits in, and can be seen clearly from the surrounding streets and canals. Bevis Marks, like its predecessor at Creechurch Lane, would have only been visible to those who knew where to look.

At the London synagogue, the courtyard was entered through a gateway off the adjacent street of Bevis Marks; a reset late-Victorian decorated stone pediment currently marks the approach (figure 34). From here, the north and west facades are visible, revealing a simple, yet refined building (figure 1). The synagogue is red brick, with Portland stone details. The main entrance is set in the center of the west face, and is marked by solid double wooden doors surrounded by a molded stone doorcase and architrave, topped by a segmental stone pediment resting on stone brackets (figure 35). The key-block above the doorway bears the date of the building in English 'A.M. 5461. 1701.' and above, within the tympanum is the Hebrew inscription commemorating the synagogue's opening for the 'New Year 5462' [September 1701] (figure 36). ${ }^{122}$ A decorative wrought-iron lamp balances above the entrance; the wealth of the congregation is displayed in these fine details. The entrance of the Bevis Marks synagogue is an

\footnotetext{
${ }^{121}$ Far more on this topic in the next chapter of this thesis

${ }^{122}$ Translation of Hebrew in Kadish, Sharman. Bevis Marks Synagogue: A Short History of the Building and an Appreciation of Its Architecture. Swindon: English Heritage, 2002. p. 8
} 
excellent example of the styles of the day. Comparable pedimented stone doorways could be found around London, including Wren's city churches. The molding and pediment is simpler than those found at St. Bride's Fleet Street (figure 37), and St. James Piccadilly (figure 27), but some of the details are there, including a similar segmental pediment on St. Bride's west entrance.

The placement of the entrance is like that of the Esnoga in Amsterdam (figure 32). The Dutch synagogue was also rectangular and of red brick, with the main entrance set in the center of the shorter length of the building, as at Bevis Marks. It too is made of stone, contrasting against the red brick, but with different details. In this case, the door is flanked by stone columns topped by a molded cornice (figure 32). The doorways of Wren's city churches, though they shared the material and stone details with Bevis Marks, were not always found on the shorter length. At St James Piccadilly, a main entrance sits in the center of the longest side of the building, and other entrances were on the west end under the steeple tower (figure 27). At St. Bride's Fleet Street entrances are also on the north and west facades, and far more detailed than the one at Bevis Marks (figure 37).

The main entrance of the London synagogue is flanked by extended segmental windows bordered with stone moldings, and plain keystones (figure 35). This window style continues around the sides of the ground floor on the north and south of the building, these lengths each with five windows (figure 38,figure 39). The upper floor has three windows on the west and east faces, the center window is wider than the others, with an elliptical top, the other two with round tops and having the same width as those below, all three bordered in the same stone dressings as the lower level windows (figure 35, figure 40). On the north and south façade, the upper level windows sit directly in line with the lower ones, and match the rounded windows of the other 
two ends (figure 38). A flat stone band visually separates the two stories. At the top of the building is a simple stone cornice and plain parapet. The elevation of Bevis Marks, with the shapes, sizes and arrangement of windows, is practically identical to many of Wren's two storied city churches, especially the arrangement at St. James Piccadilly (figure 14). Here too, the stone dressings contrast with the red brick building. St. James, however, has more carved detail in the stone moldings, and the corners of the building are also marked in stone. In Amsterdam, the exterior façade details are strikingly different from Bevis Marks after the comparison to the Wren city churches. Here the building has three levels, the only stone contrasting with the red brick is in the door frame, and the highly detailed cornice and parapet (figure 32). The windows take on a symmetrical arrangement, though unlike those in London, and none are bordered in stone, the red brick dominates the façade. Their shape also separates them from those found in London - the lower and upper levels are square and rectangular, the middle level are all round headed, a style closer to what was seen at the Huguenot Temple at Charenton (figure 19). In addition, the Esnoga's iconic brick buttresses (figure 41) suggesting Leon Templo's depiction of Solomon's Temple (figure 33) are missing at Bevis Marks.

Along with the exterior details, the scale of the worship space at Bevis Marks is also directly comparable to Wren's city churches, measuring $80 \mathrm{ft}$. by $50 \mathrm{ft}$., matching St. James Piccadilly, which had Wren's ideal size of $90 \mathrm{ft}$. by $60 \mathrm{ft}$. (figure 27, figure 28). Contrasting to these proportions is the Esnoga, which was monumental in size, the floor plan also rectangular, but over fifty percent longer and wider, as well as taller than the religious architecture of London, having three levels of windows (figure 32). The three sets of floor plans, of Bevis Marks, a Wren city church like St James Piccadilly and the Dutch Esnoga, are comparable in that they are ritualized western religious spaces; all three are based on the Roman basilica form, with 
central and side aisles. There is a striking similarity to the plan of the London synagogue and that of St. James Piccadilly. Beyond their similar proportions, the main spaces of both buildings are defined by five bays, separated by columns, five on each side. At Bevis Marks, a sixth bay exists as an entrance and circulation space (figure 28); at St James Piccadilly this sixth bay space is marked by the iconic Wren steeple (figure 27). In Amsterdam, the synagogue space doesn't quite follow the same clearly defined bay plan. Instead, the interior in marked by two sets of columns between the aisle and nave spaces of the basilica form (figure 42). Four massive ionic freestanding columns, two on each side of the central aisle, support the roof, the galleries are supported separately by six pillars per side, which do not continue to the roof plane (figure 43). The interior arrangement of the Amsterdam and London synagogues are nearly the same, due to the fact that they are both designed as traditional Sephardic worship spaces, which was also true for Creechurch Lane. The attention is on both the east and the west, the ark and the bimah. The seats run parallel to the length of the building, filling the space of the main level and the galleries, facing each other where they meet in the center aisle.

The details of the interior of the synagogue at Bevis Marks are different from both the Wren churches, particularly St James Piccadilly and St Bride's Fleet Street, as well as the Esnoga. Due to the shared proportions, five bay layout and two-storied space, Bevis Marks can seem closest in character to the city of London parish churches, but it lacks Wren's innovative two-storied gallery design. Like St James Piccadilly, the main worship space is flooded with light from the large windows, which are deeply recessed within the walls (figure 26). Because good lighting is imperative to reading the Torah scrolls, Bevis Marks also has seven low hanging brass chandeliers, which even today are still fit with candles. One chandelier and four candlesticks were donated from the congregation in Amsterdam; earlier historians of the 
synagogue are inclined to believe it is the one larger chandelier in the center and the four large matching candlesticks on the reading desk (figure 44). ${ }^{123}$ The synagogue's ceiling is flat with a simple plaster cornice. From where the chandeliers hang are rosette details, made by the London craftsman Andrea Hatt (figure 45). ${ }^{124}$ Compared to the ceiling of the Esnoga in Amsterdam, and also many of Wren's city churches, Bevis Marks is incredibly simple. The central aisle of the Esnoga is covered by a large barrel vault, and the galleries are also smaller barrel vaults (figure 43). Wren's St James Piccadilly, St Bride's Fleet Street, and St Clement Dames, where we know the craftsmen had done previous work, all contain vaulted naves, with smaller, separate vaults over the galleries (figure 24, figure 25, figure 26). The construction and large scale renovations of many of the city churches had benefitted from financial assistance of the newly implemented coal tax, while the synagogue's construction required financial capital directly from the congregation dues and private contributions, which perhaps limited some of their structural options. Some of the smaller and simpler of Wren's city churches however, do have an incredibly similar interior character as Bevis Marks. One in particular, St Benet Paul's Warf, which like the London synagogue, escaped the destruction of WWII and still retains its original interior, has the same flat roof that spans both the main worship space and the gallery, just as at Bevis Marks (figure 46).

The original worship space at Creechurch Lane following the 1674 remodeling, is not one to be overlooked when comparing interior features. In fact, two individuals, Antonio Gomes Serra of the Sephardic congregation, and the carpenter Thomas Clarke, were involved in both construction projects. ${ }^{125}$ Perhaps this explains the details in common between Creechurch Lane

\footnotetext{
${ }^{123}$ Gaster, 1901, p. 83

${ }^{124}$ Gaster, 1901, p. 84

${ }^{125}$ Their names are in both building contracts: for Creechurch Lane, see appendix in Samuel, 1924, Bevis Marks reprinted in Gaster, 1901
} 
and Bevis Marks, in particular the decorative wood paneling found on the walls of both levels of the synagogue (figure 29). The three gallery arrangement, found in both synagogues (figure 10, figure 28), was not found in the Esnoga, but can be found in a few Wren city churched, including St. Clement Danes, and it was common in non-conformist meeting halls in England during the period. Avis's Quaker background is not evidence that the Jewish congregation took this design feature directly from Quaker practice, especially since Avis is not known to have built any Quaker meeting halls. ${ }^{126}$ The addition of three galleries at Creechurch Lane likely came from a desire for additional seating in the small space, and Bevis Marks needed to meet these same demands. It is also interesting to note that in some ways the Creechurch Lane synagogue had certain characteristics more in line with Wren's parish churches - the galleries were supported by columns and arches, that were replicated on the gallery level and incorporated the galleries into the open basilica plan, similar to St. James Piccadilly and others (figure 26). The galleries at Bevis Marks do not share these features, they are instead detached from the ceiling, more in line with those found in the Esnoga (figure 12, figure 43).

On the surface it appears that the synagogue at Bevis Marks took much of its design from these earlier precedents, both in London and Amsterdam. However, it also stands alone; many details make this space unique, like the members of the London congregation itself. On the exterior, the building is distinctly English, blending in with the exteriors of many of Wren's city churches. It is a simplified version though, which does not attempt to stand out in the city's streetscape. The interior also has the scale of the London city church, perhaps making its character feel more 'English' overall, but certain features are distinct, some coming from Sephardic tradition, from Amsterdam, or the Creechurch Lane site. Other details, that separate the space from both Wren churches and also the Esnoga, perhaps come from the skilled group of

${ }^{126}$ Kadish, 2002, 8 
craftsmen and the financial capital the congregation was willing to put into the project. These details, like the ceiling rosettes, the curving of the galleries of the east end, the highly skilled wood and brass work throughout, give the space an individual impression (figure 47, figure 45, figure 29). The building is a representation of those who worshipped there, with strong ties to both England and Amsterdam, but also a distinctive group, characteristic to the period in which they lived. 


\begin{abstract}
5
Return to the Temple of Jerusalem:

Parallel Themes in Synagogue and Church Architecture
\end{abstract}

In the Vlooienburg district of mid-seventeenth century Amsterdam, part of the city's Jewish quarter, crowds of both locals and tourists flocked to a private museum, at a house marked by the sign of Solomon's Temple. Inside, visitors could marvel at a number of reconstructed ceremonial objects, from altars and priestly garments to a large-scale copper menorah (figure 48). ${ }^{127}$ The main attractions however, were large, wooden models of the Temple of Solomon and the Tabernacle of Moses, from the famed biblical site of ancient Jerusalem. ${ }^{128}$ The museum, that attracted Christians and Jews alike, was in the home of the models' creator, Rabbi Jacob Judah Leon, who added the surname 'Templo' due to the fame he gained for his reconstructions of Solomon's Temple. Little is known regarding the details of Templo's life (1602-1675); scholars say he was of Spanish ancestry, born in Hamburg, emigrated to Middleburg, and then finally to Amsterdam, where he was a rabbi, children's teacher, for the Dutch Sephardic synagogue, as well as a writer, with an avid interest in biblical architecture. ${ }^{129}$

\footnotetext{
${ }^{127}$ Offenberg, Adri. “Dirk van Santen and the Keur Bible: New Insights into Jacob Judah (Arye) Leon Templo's Model Temple." Studia Rosenthaliana 37 (2004): 401 - 422.

${ }^{128}$ In the preface of Retrato, Leon states the dimensions of the model to be $20 \mathrm{ft} \times 10 \mathrm{ft} \times 7 \mathrm{ft}$. Offenburg, 1988

${ }^{129}$ Current studies on Leon Templo: Offenberg, 2004; Offenberg, A.K. "Jacob Jehuda Leon (1602-1675) and His Model of the Temple." In Jewish-Christian Relations in the 17th Century, edited by J. van den Berg and Ernestine G.E. van der Wall, 95-118. Dordrecht; Boston; London: Kluwer Academic Publishers, 1988; Rosenau, Helen. "Jacob Judah Leon Templo's Contribution to Architectural Imagery." Journal of Jewish Studies XXIII, no. 1 (1972): 72-81.
} 
His model of the Temple of Solomon was so popular that his exhibit travelled throughout the Netherlands, was presented to the Dutch and then British courts, and continued to be displayed in England well after the rabbi's death in $1675 .{ }^{130}$ In parallel with the exhibits, Templo published a number of pamphlets describing the models, which translated in a numerous languages and included a range of different artists' illustrations based on his reconstruction (figure 33, figure 49, figure 50). ${ }^{131}$ Leon Templo remains an obscure figure in history, but his work was innovative in the fields of both book illustrations and model construction. Building models had been common for centuries and used regularly in the construction process, but creating one based on an ancient site that no longer existed was entirely new and reveals the emergent interest in 'primitive architecture' in early modern architectural thought. ${ }^{132}$

The popularity of Leon Templo's travelling exhibit of Solomon's Temple came from more than just curiosity or intellectual interest, but the wave of messianic fever that swept both Jewish and Christian circles, reaching its peak in the middle of the seventeenth century. ${ }^{133}$ Both groups believed the return of the Messiah was imminent, which meant the reconstruction of the Temple of Jerusalem would be required, and Templo's model provided insight into what this might look like. It was in fact Leon Templo's close associate, the Christian Hebraist Adam Boreel, who financed the model of the Temple made in Amsterdam. ${ }^{134}$ Of course, he was not the first to take on this study; since the medieval period, builders and theologians were deeply interested in the physical dimensions of the Temple of Jerusalem. This interest had not waned, as

\footnotetext{
${ }^{130}$ The model was on display again during the late $18^{\text {th }}$ century, along with Templo's pamphlets being republished. Offenburg, 1988

${ }^{131}$ Pamphlets include: Afbeelding van den Tempel Salomonis, Amsterdam, 1644; Retrato del tabernaculo de Moseh, Amsterdam, 1654; De templo Hierosolymitan, Helmstadt, 1665; Retrato Del Templo de Selomoh republished in 1778 by M.P. Decastro, London.

${ }^{132}$ Rosenau, Helen. “Jacob Judah Leon Templo's Contribution to Architectural Imagery.” Journal of Jewish Studies XXIII, no. 1 (1972): 72-81.

${ }^{133}$ For Jews, it was the disappointment over Sabbatai Zevi, the fake-messiah, who converted to Islam in 1666

${ }^{134}$ Kaplan, 2002, p. 663
} 
the studies of the late-seventeenth century mathematician Isaac Newton demonstrate - he believed the form and geometry of the Temple of Jerusalem was key to understanding God's plan, and that the 'cubit', which he sought to quantify, was a divine unit of construction (figure 51). ${ }^{135}$ Only with hindsight can we see that the seventeenth century brought major shifts in political thought that would lead to the separation of the functions of church and state in the West. At the time however, only a very small minority of a people considered this future. The assumed link between religious and state authority was still very strong, and the Temple of Solomon provided means of articulating this relationship, while providing monarchs biblical legitimacy for their divine rights. ${ }^{136}$ Protestants and Catholics, who both claimed to be the true heirs of Israel, looked to the Temple as a model for civic life. In reference to conquest and colonization, Spanish Catholic missionaries compared their work with the deeds of the biblical king. ${ }^{137}$ The Spanish monarch Philip II, identified himself with Solomon, fashioning his royal palace and monastery of El Escorial on the ground plan of the ancient Temple in Jerusalem (figure 52). New England Puritans adopted the Temple of Solomon as an archetype for their colonial settlements, while in England, millenarians had identified their nation as the 'New Israel' and their Anglican churches with the Temple of Jerusalem. ${ }^{138}$

The major source on the Temple of Solomon, until Leon Templo's publications in the 1640-70's, was the highly prominent study by Spanish Jesuit Fathers, J.B. Villalpando and H. Prado, whose large volumes of In Exechielem Explanations, were published with the support of Philip II in 1596 and 1605 (figure 53, figure 54). ${ }^{139}$ The Spanish scholars based their

\footnotetext{
${ }^{135}$ Katz, 1992, p. 64

${ }^{136}$ Doll, Peter. "The Architectural Expression of Primitive Christianity: William Beveridge and the Temple of Solomon." Reformation and Renaissance Review 13, no. 2 (2011): 275-306. doi:10.1558/rrr.vl3i2.275.

${ }^{137}$ Doll, 2011, more examples

${ }^{138}$ Doll, 2011

${ }^{139}$ Rosenau, Helen, 1972
} 
reconstruction on passages from the Old Testament, and connected the architectural orders of Vitruvius to biblical authority by depicting Solomon's Temple with columns of the Corinthian order (figure 55). ${ }^{140}$ This Renaissance-styled Temple was widely accepted as an accurate reconstruction, though some later scholars criticized Villalpando for ignoring Jewish sources, especially the well-known writings of first-century Roman-Jewish scholar Josephus and the renowned medieval scholar and rabbi, Maimonides.

In particular, Sir Christopher Wren, who took on the study of the physical reconstruction of Solomon's Temple with the same seriousness as any built project, rejected Villalpando's depiction in favor of a more historically accurate representation. Wren was a highly devout Christian, but also a scholar of a generation influenced by the legacy of skeptics like Francis Bacon, which lead the English architect to challenge certain architectural traditions. Deeply interested in Vitruvius and biblical architecture, Wren wrote a discourse on the Classical Orders. Like Vitruvius, he believed the Orders found their origin in nature, but as a radical departure from Renaissance thinking, he dismissed the idea that they were based on human proportions, and instead argued that the first column was the primitive Tyrian order, used in antiquity. ${ }^{141}$ In Tract V of Wren's discourse on architecture, the English architect discredits the prior study of Solomon's Temple, based on his own understanding of the development of the Classical Order.

Villalpandus hath made a fine Romantick Piece after the Corinthian Order, which in that Age was not used by any Nation: for the First Ages used grosser Pillars then Dorick. In after Times they began to refine from the Dorick, and afterwards improv'd into a Slenderer Pillar, and Leavy Capital of various inventions, which they call'd Corinthian. So that if we run back to the Age of Solomon, we may with reason believe They used the Tyrian Manner,

\footnotetext{
${ }^{140}$ Soo, Lydia. Wren's "Tracts” on Architecture and Other Writings. Cambridge, NY: Cambridge University Press, 1998. p. 129

${ }^{141}$ Quoted in Soo, 1998
} 
as gross at least as the Dorick, and that the Corinthian Manner of Villalpandus is meer fancy. ${ }^{142}$

Wren shared an interest in historical accuracy with the rabbi, Jacob Judah Leon Templo, whose model of Solomon's Temple was known to have corrected the errors of the Spanish Jesuit depiction. In his own writing and correspondences, Wren makes no mention of Templo's travelling exhibit, which was on public display in London in 1675. However, we do know from other sources that he was aware of the rabbi's reconstruction, and his obsessive personal interest in the subject, and the popularity of Templo's model and corresponding publications, makes it hard to believe he did not visit the model himself while it was on display. Leon Templo, aware of the reputation of the English architect, had an associate, Constantine Huygens write a letter of introduction to Wren, dated October 7, 1674, describing Templo's work and intention of bringing the model to London. ${ }^{143}$ Further, in an entry from September 6, 1675, Robert Hooke noted in his diary that the Temple of Solomon had been the topic of discussion at a dinner party: “At Mr Storys coald venison and coadling. With Sr Chr. Wren. Long Discourse with him about the module of the temple at Jerusalem. ${ }^{, 144}$ Wren had a profound scholarly interest in the reconstruction of Solomon's Temple as well as other examples of biblical architecture, but he was clearly not alone in this endeavor, as the subject was at the forefront of the minds of many of his contemporaries.

Combined with the parallel attentions of Hebraists, millenarians, and general Protestant interest in the early roots of the Christian church, or 'primitive Christianity', these studies of the Temple of Jerusalem took architectural form in the religious buildings of the period. Discussed

\footnotetext{
${ }^{142}$ Quoted in Soo, 1998

${ }^{143}$ Offenberg, Adri. "Dirk van Santen and the Keur Bible: New Insights into Jacob Judah (Arye) Leon Templo's Model Temple." Studia Rosenthaliana 37 (2004): 401 - 422.

${ }^{144}$ Hooke, Diary 1672-80, 179, quoted in Soo, 1998
} 
in the Hebrew Bible, the Temple in Jerusalem built by King Solomon was the holiest place in the Jewish world, the location of the permanent presence of God among his chosen people. Reformers, interested in connecting back with the early scripture of the Church, became sympathetic with their Jewish history in order to embrace the iconography of Solomon's Temple. This hesitant acceptance of their own Jewish past, in terms of church architecture, was described by an author of a small pamphlet, De templis, from 1638, which argued that Christians should not 'fear ... to build a Christian church so like Solomon's Temple' out of worry that it would resemble a synagogue. ${ }^{145}$ Since antiquity, synagogues and churches have borrowed from one another, as well as from the culture surrounding them; an example lies in both religions' adaptation of the classical basilica form during the Roman period. It was to this 'primitive' past that the French Protestant architect, Solamon de Brosse, looked for a form in rebuilding the 'Temple' at Charenton in 1623, named with a clear reference to the Temple of Solomon. The 'Temple' at Charenton had a simple Roman basilica plan, with central and side aisles covered by barrel vaulting, that despite being demolished in 1686, was highly influential on continental Protestant architecture (figure 19). ${ }^{146}$ The classical basilica form, with limited decoration, and simple barrel vaults, became standard for Dutch Protestant churches in the seventeenth century, and as already discussed, shared the form with the 1675 Amsterdam Sephardic Synagogue, the Esnoga. In a period when their religion may have been tolerated, but not fully accepted in society, it would not have been unusual for a Jewish congregation to look to trends in mainstream building forms for their synagogue; they did the same during the Roman period, when the basilica was initially adopted.

\footnotetext{
${ }^{145}$ Quoted from Doll, 2011

${ }^{146}$ Rosenau, Helen. "The Synagogue and Protestant Church Architecture." Journal of the Warburg and Courtauld Institutes 4, no. 1/2 (1940): p. 81
} 
In England, where church reformers had identified their country as the 'New Israel', the Great Fire of 1666 had destroyed many of the city's medieval churches and provided an opportunity to build new ones that reflected the 'primitive' Christianity of their Protestant faith. ${ }^{147}$ During the service on the day of the opening of Wren's rebuilt St. Peter, Cornhill, the church's rector, Revd. Dr. William Beveridge compared the parish church's rebuilding with that of the rebuilding of the Temple of Jerusalem in 166 BCE by Judas Maccabaeus:

We of this parish have cause to be transported with joy and gladness, and to spend this day in praising ... God, for that our church, which hath lain waste for above five times three years, is now at last rebuilt and fitted again for His worship and service. For what the altar and Temple were unto the Jews then, the same will our church be unto us now.... Was the Temple a house of prayer to them? So is this church to us. ${ }^{148}$

On a further note, the acclaimed Anglican preacher commented on his church's built form, in particular the existence of the chancel in the Protestant architecture (figure 23). His argument was that this was not a Catholic representation, but instead a symbolic form that could be traced back to the Temple of Solomon. Within the temple, it was the Holy of Holies that marked the most sacred place, where the divine was present on earth, and in this same way, the chancel of the Anglican church was a continuation of this presence. ${ }^{149}$ This symbolic connection to the Jewish Temple of Jerusalem and the 'primitive' Christianity that reformers embraced, was further pronounced in the architectural form of the chancel reredos of the late seventeenth century and well into the eighteenth. References to the Temple and the Hebrew Bible were commonly found in the limited decoration of the reredos of Wren's city churches, which displayed the biblical Tablets of Law, often held by figures of Aaron and Moses (figure 56, figure 57). This was also a common decorative theme of the ark in many synagogues, where the

\footnotetext{
147 'Primitive Christianity' term used in Doll, 2011

${ }^{148}$ Doll, 2011, p. 277

${ }^{149}$ Doll, 2011, p. 277
} 
most holy object, the Torah scrolls, are housed. Comparing the ark in the Esnoga with the painted wall behind the alter in the 'Temple' at Charenton reveals that both were decorated with the Tablets of Law, shared imagery from the Hebrew Bible (figure 20, figure 43). ${ }^{150}$ This theme continued in London, where the ark at Bevis Marks, built by the team of English craftsmen headed by Avis, is strikingly similar to many of the reredos of Wren's city churches, which are also decorated and in the shape of the Tablets of Law (figure 16, figure 57). The protestant churches and synagogues of the period not only shared the basilica plan, but also the decorative themes of their ritual furniture. As a result, the worship spaces were incredibly similar in form and character.

Architectural historians often seem fixated on assigning a direct, linear trail of architectural design influence to a building, and existing literature on the London synagogue, Bevis Marks, appears to have done just this. A building with a rich and complex history, has over the years been summed up into a simple, finalized description that the Sephardic synagogue is directly based on the architecture of the Amsterdam Esnoga and Christopher Wren city churches. It is clear from the analysis that this statement is not incorrect, however, this summary ignores the fact that all three - Bevis Marks, the Esnoga, and Wren's churches - existed within the same religious, political and architectural climate, and together tell a larger story of religious architecture in the late-seventeenth and early-eighteenth centuries. The Esnoga in Amsterdam, for example, was groundbreaking for Jews in the history of synagogue architecture, but derived its form from Dutch Protestant church design, which in itself was inspired by the Jewish Temple in Jerusalem. As much as this was a subject of interest to those at the Esnoga, it also influenced the work of Christopher Wren in England, that Bevis Marks would then borrow from. To further

${ }^{150}$ Rosenau, 1940, p. 82 
complicate matters of influence, this is a time when builders themselves were Christian, seen in both Bouman, architect of the Esnoga, and Avis, of Bevis Marks. It would still be another two centuries before Jews themselves reached the architectural profession. Their progress in this field was likely impeded by the fact that craftsmen's guilds were strictly limited to Christians throughout the middle ages and into the modern period. ${ }^{151}$ There was an unprecedented surge of in Jewish-Protestant relations during the mid to late-seventeenth century, evidenced in the correspondences between Sephardic scholars like Menasseh ben Israel and Leon Templo with their Protestant contemporaries, especially those in England. It is during this period that Jewish synagogues and the churches of different Protestant denominations become remarkably similar, to the point that they are practically interchangeable, even in regards to the symbolism and decorative scheme of ritual furniture.

This give and take of influence between synagogue and church forms occurred within such a compact timeframe, that the boundaries of what exactly is influencing the other begins to blur, and the larger story of religious architecture of the late-seventeenth century begins to be exposed. Because of this, there is a flaw in the claim that Bevis Marks was designed from direct influence from the Esnoga and/or the Wren city churches, as it dismisses the wider perspective that necessarily includes all of them. The full story has yet to be told, but what is clear at this point in the research is that independent projects like the Esnoga, Creechurch Lane, and Bevis Marks, which were built outside of mainstream construction practices due to their Jewish patrons, are key to examining and understanding the larger themes in religious architecture of the period. There are other synagogues, including the Ashkenazi 'Great Synagogue' of London, rebuilt in the eighteenth century, but lost during WWII, that are equally comparable to trends in

\footnotetext{
${ }^{151}$ Kadish, Sharman. “Constructing Identity: Anglo-Jewry Synagogue Architecture.” Architectural History 45, no.
} 2002 (2013): p. 388 
eighteenth century Anglican church form (figure 58). Further, the mid to late-seventeenth century saw a rise in non-conformist meeting houses in England, like those built by the Quakers, that also fall within these themes, and deserve a place within the larger discussion. Sir Christopher Wren certainly carries a legacy in western religious architecture, but he was also a product of the larger trends surrounding his life. The work done outside of his authority provide insight into the impacts of Wren's designs, but also the greater religious trends that influenced sacred architecture overall.

Wren's England was one of growing religious toleration, and there are further arguments waiting to be made regarding the role of similar themes within religious architecture in the creation of tolerant communities. Bevis Marks Synagogue provides us with an example of a congregation that experienced this tolerance first hand and became identified as 'English-Jewish' participants in mainstream London society, instead of Jewish and 'alien' to the nation. Their architectural endeavors were not trivial, and includes both Bevis Marks, and their remodeled space at Creechurch Lane. At their openings, both synagogues would have been considered amongst the finest examples of religious architecture in London, confirming the congregation's impressive social status in the city. Whether their choices in architectural form and style are the after-effects of an already existing toleration or the cause itself for the growing tolerance, has yet to be determined. The answer to this question lies in the greater story, that is still left untold. 


\section{Bibliography}

Barnett, Lionel D., ed. Bevis Marks Records: Being Contributions to the History of the Spanish and Portuguese Congregation of London. Oxford: University Press, 1940.

Bell, Dean. Jews in the Early Modern World. Lanham: Rowman \& Littlefield, 2008.

Biale, David, ed. Cultures of the Jews: A New History. 1st ed. New York: Schocken Books, 2002.

Bland, Kalman P. The Artless Jew: Medieval and Modern Affirmations and Denials of the Visual. Princeton: Princeton University Press, 2000.

Butler, David. The Quaker Meeting Houses of Britain. London: Friends Historical Society, 1999.

Cesarani, David. Port Jews: Jewish Communities in Cosmopolitan Maritime Trading Centres, 1550-1950. London; Portland: Frank Cass, 2002.

Chazan, Robert, ed. Church, State, and Jew in the Middle Ages. New York: Behrman House, 1980.

Colvin, H.M., and J. Mordaunt Crook, eds. The History of the King's Works, Volume V, 16601782. London: Her Majesty's Stationary Office, 1976.

Diamond, A.S. "The Community of the Resettlement, 1656-1684." Transactions of the Jewish Historical Society of England 24 (1974): 134-50.

Doll, Peter. "The Architectural Expression of Primitive Christianity: William Beveridge and the Temple of Solomon." Reformation and Renaissance Review 13, no. 2 (2011): 275-306. doi:10.1558/rrr.vl3i2.275.

Du Prey, Pierre. Hawksmoor's London Churches: Architecture and Theology. Chicago: University of Chicago Press, 2000.

Endelman, Todd. Radical Assimilation in English Jewish History, 1656-1945. Bloomington: Indiana University Press, 1990.

. The Jews of Britian, 1656 to 2000. Berkeley; London: University of California Press, 2002.

Gartner, LP. “A Quarter Century of Anglo-Jewish Historiography.” Jewish Social Studies 48, no. 2 (1986): 105-26. 
Gaster, Moses. History of the Ancient Synagogue of the Spanish and Portuguese Jews. London: Bevis Marks, 1901.

Godfrey, Walter. “The Church of St. Bride's Fleet Street.” Monograph 15. London: London Survey Committee, 1944. http://www.british-history.ac.uk/source.aspx?pubid=1267.

“Heavens above: Bevis Marks Synagogue, City of London.” RIBA Journal 104, no. 4 (1997): $32-33$.

Heng, Geraldine. "The Invention of Race in the European Middle Ages I: Race Studies, Modernity, and the Middle Ages.” Literature Compass 8, no. 5 (May 02, 2011): 258-74.

- "The Invention of Race in the European Middle Ages II: Locations of Medieval Race." Literature Compass 8, no. 5 (May 02, 2011): 275-93.

Hubka, Thomas. Resplendent Synagogue: Architecture and Worship in an Eighteenth-Century Polish Community. Hanover, NH: Brandeis University Press published by University Press of New England, 2003.

Hyamson, Albert M. "The Lost Tribes, and the Influence of the Search for Them on the Return of the Jews to England." The Jewish Quarterly Review 15, no. 4 (1903): 640-76.

. The Sephardim of England: A History of the Spanish and Portuguese Jewish Community 1492-1951. London: Methuen, 1951.

Israel, Jonathan. European Jewry in the Age of Mercantilism, 1550-1750. Oxford; New York: Clarendon Press; Oxford University Press, 1985.

— "Spain and the Dutch Sephardim, 1609-1660." Studia Rosenthaliana 12, no. 1/2 (1978): $1-61$.

_. "The Economic Contribution of Dutch Sephardi Jewry to Holland's Golden Age, 15951713." Tijdschrift Voor Geschiendenis 96 (1983): 505-35.

Jamilly, Edward. The Georgian Synagogue: An Architectural History. London: Working Party on Jewish Monuments in the UK and Ireland, 1999.

Kadish, Sharman. Bevis Marks Synagogue: A Short History of the Building and an Appreciation of Its Architecture. Swindon: English Heritage, 2002.

ed. Building Jerusalem: Jewish Architecture in Britain. London; Portland: Vallentine Mitchell, 1996.

. "Constructing Identity: Anglo-Jewry Synagogue Architecture." Architectural History 45, no. 2002 (2013): 386-408. 
—. Jewish Heritage in England: An Architectural Guide. Swindon: English Heritage, 2006. . "The Jewish Built Heritage in the UK and Ireland." European Judaism 34, no. 2 (2001): $14-29$.

T. The Synagogues of Britain and Ireland: An Architectural and Social History. New Haven: Yale University Press, 2011.

Kagan, Richard. Atlantic Diasporas: Jews, Conversos, and Crypto-Jews in the Age of Mercantilism, 1500-1800. Baltimore: Johns Hopkins University Press, 2009.

Kaplan, Debra. "Jews in Early Modern Europe: The Sixteenth and Seventeenth Centuries." History Compass 10, no. 2 (2012): 191 - 206.

Kaplan, Yosef. An Alternative Path to Modernity: The Sephardi Diaspora in Western Europe. Leiden: Brill, 2000.

_ "Bom Judesmo: The Western Sephardic Diaspora." In Cultures of the Jews: A New History, edited by David Biale, 638-69. 1st ed. New York: Schocken Books, 2002.

. "Political Concepts in the World of Portuguese Jews of Amsterdam During the Seventeenth Cenutry: The Problem of Exclusion and the Boundaries of Self-Identity." In Menasseh Ben Israel and His World, edited by Yosef Kaplan, Henry Mechoulan, and Richard Popkin, 45-62. Leiden, 1989.

_. "The Jewish Profile of the Spanish Portuguese Community of London During the 17th Century." Judaism 41, no. 3 (1992): 229-41.

—. "The Jewish Profile of the Spanish-Portuguese Community of London During the 17th Century." In An Alternative Path to Modernity. Leiden; Boston; Koln: Brill, 2000.

Kaplan, Yosef, Henry Méchoulan, and Richard Popkin, eds. "Menasseh Ben Israel and His World.” Leiden: E.J. Brill, 1989.

Katz, David. Philo-Semitism and the Readmission of the Jews to England, 1603-1655. Oxford; New York: Clarendon Press; Oxford University Press, 1982.

- The Jews in the History of England, 1485-1850. Oxford; New York: Clarendon Press; Oxford University Press, 1994.

_ . "The Marginalization of Early Modern Anglo-Jewish History." In The Jewish Heritage in British History: Englishness and Jewishness, edited by Tony Kushner, 60-77. London: Frank Cass, 1992.

Kendall, Derek. The City of London Churches: A Pictorial Rediscovery. London: Collins \& Brown, 1998. 
Krinsky, Carol Herselle. Synagogues of Europe: Architecture, History, Meaning. New York: Architectural History Foundation, 1985.

Krummel, Miriamne Ara. Crafting Jewishness in Medieval England: Legally Absent, Virtually Present. New York: Palgrave Macmillan, 2011.

Kushner, Tony. "Social Inclusion: A Historian's Perspective.” Immigrants \& Minorities 20, no. 2 (2001): $75-83$.

- , ed. The Jewish Heritage in British History: Englishness and Jewishness. London; Portland: F. Cass, 1992.

Lavezzo, Kathy. “The Minster and the Privy: Rereading The Prioress's Tale.” PMLA 126, no. 2 (March 2011): 363-82.

Li, Shiqiao. Power and Virtue: Architecture and Intellectual Change in England 1660-1730. London: Routledge, 2007.

Lindsay, Paul. The Synagogues of London. London: Vallentine Mitchell, 1993.

Louw, Hentie. “The 'Mechanick Artist' in Late Seventeenth-Century English and French Architecture: The Work of Robert Hooke, Christopher Wren and Claude Perrault Compared as Products of an Interactive Science.” In Robert Hooke: Tercentennial Studies, edited by Michael Cooper and Michael Cyril William Hunter, 181-99. Aldershot, Hants, England; Burlington, VT: Ashgate, 2006.

Matar, NI. "The Idea of the Restoration of the Jews in English Protestant Thought, 1661-1701." Harvard Theological Review 78, no. 1 (1985): 115-48.

Méchoulan, Henry. "Menasseh Ben Israel and the World of the Non-Jew." In Menasseh Ben Israel and His World, edited by Yosef Kaplan, Henry Méchoulan, and Richard Popkin, 8397. Leiden: E.J. Brill, 1989.

Mellinkoff, Ruth. Outcasts: Signs of Otherness in Northern European Art of the Late Middle Ages. Berkeley: University of California Press, 1993.

Mundill, Robin R. "Out of the Shadow and Into the Light: The Impact and Implications of Recent Scholarship on the Jews of Medieval England 1066-1290." History Compass 9, no. 8 (2011): 572-607.

Offenberg, A.K. "Jacob Jehuda Leon (1602-1675) and His Model of the Temple." In JewishChristian Relations in the 17th Century, edited by J. van den Berg and Ernestine G.E. van der Wall, 95-118. Dordrecht; Boston; London: Kluwer Academic Publishers, 1988.

Offenberg, Adri. "Dirk van Santen and the Keur Bible: New Insights into Jacob Judah (Arye) Leon Templo’s Model Temple.” Studia Rosenthaliana 37 (2004): 401 - 422. 
Pevsner, Nikolaus. London. 3rd ed. Harmondsworth: Penguin, 1973.

Popkin, Richard H, and Gordon M Weiner, eds. Jewish Christians and Christian Jews: From the Renaissance to the Enlightenment. Dordrecht; Boston: Kluwer Academic Publishers, 1994.

Popkin, Richard H. "The Rise and Fall of the Jewish Indian Theory." In Menasseh Ben Israel and His World, edited by Yosef Kaplan, Henry Méchoulan, and Richard H. Popkin, 63-82. Leiden: EJ Brill, 1989.

Rosenau, Helen. “Jacob Judah Leon Templo’s Contribution to Architectural Imagery.” Journal of Jewish Studies XXIII, no. 1 (1972): 72-81.

. The Ideal City: Its Architectural Evolution in Europe. 3rd ed. London; New York: Methuen, 1983.

— "The Synagogue and Protestant Church Architecture." Journal of the Warburg and Courtauld Institutes 4, no. 1/2 (1940): 80 - 84.

- Vision of the Temple: The Image of the Temple of Jerusalem in Judaism and Christianity. London: Oresko Books, 1979.

Ross, J.M. "Naturalisation of Jews in England." Transactions of the Jewish Historical Society of England 24 (1974): 59-72.

Rowe, Nina. The Jew, the Cathedral and the Medieval City: Synagoga and Ecclesia in the Thirteenth Century. New York: Cambridge University Press, 2003.

Rubens, Kenneth. "Bevis Marks Synagogue and the City Churches." Transactions of the Jewish Historical Society of England 37 (2002): 117-31.

Rubin, Miri. Gentile Tales: The Narrative Assault on Late Medieval Jews. New Haven, CT: Yale University Press, 1999.

Ruderman, David. Early Modern Jewry: A New Cultural History. Princeton, NJ: Princeton University Press, 2010.

- Jewish Thought and Scientific Discovery in Early Modern Europe. New Haven, CT: Yale University Press, 1995.

Samuel, Wilfred S. "The First London Synagogue of the Resettlement [Creechurch Lane]." Transactions of the Jewish Historical Society of England 10 (1924): 1-147.

Sapir Abulafia, Anna. Christian-Jewish Relations, 1000-1300: Jews in the Service of Medieval Christendom. Harlow, England: Longman, 2011. 
Schless, Nancy Halverson. "Peter Harrison, the Touro Synagogue, and the Wren City Church." Winterthur Portfolio 8 (1973): 187-200.

Shapiro, Barbara. A Culture of Fact: England, 1550-1720. Ithaca, NY: Cornell University Press, 2000.

- Probability and Certainty in Seventeenth-Century England: A Study of the Relationships Between Natural Science, Religion, History, Law, and Literature. Princeton, NJ: Princeton University Press, 1983.

Skinner, Patricia, ed. The Jews in Medieval Britain: Historical, Literary, and Archaeological Perspectives. Rochester: Boydell \& Brewer, 2003.

Soo, Lydia. Wren's "Tracts" on Architecture and Other Writings. Cambridge, NY: Cambridge University Press, 1998.

Stacey, Robert C. "The Conversion of Jews to Christianity in 13th Century England." Speculum 67, no. 2 (1992): 268-83.

Stansky, Peter. "Anglo-Jew or English/British? Some Dilemmas of Anglo-Jewish History." Jewish Social Studies, 1994, 159-78.

Stell, Christopher. Nonconformist Chapels and Meetinghouses in Eastern England. Swindon: English Heritage, 2001.

Summerson, John. Architecture in Britain, 1530-1830. Harmondsworth: Penguin Books, 1970.

Templo, Jacob Judah Aryeh Leon. "Retrato Del Templo de Selomoh." Edited by M.P. Decastro. Eighteenth Century Collections Online. London: W. Bailey, Wellclose-Square, 1778. http://find.galegroup.com.proxy.its.virginia.edu/ecco/infomark.do?\&source=gale \&prodId= ECCO\&userGroupName=viva_uva\&tabID=T001\&docId=CW101970212\&type=multipage \&contentSet=ECCOArticles\&version=1.0\&docLevel=FASCIMILE.

Trivellato, Francesca. The Familiarity of Strangers: The Sephardic Diaspora, Livorno, and Cross-Cultural Trade in the Early Modern Period. New Haven, CT: Yale University Press, 2009.

Upton, Dell. Holy Things and Profane: Anglican Parish Churches in Colonial Virginia. New York; Cambridge: Architectural History Foundation; MIT Press, 1986.

Wolf, Lucien. "Crypto-Jews in the Canaries." Transactions of the Jewish Historical Society of England 7 (1911): 97-112.

. "Crypto-Jews Under The Commonwealth." Transactions of the Jewish Historical Society of England 1 (1893): 55-88. 
—. "Status of the Jews in England after the Re-Settlement." Transactions of the Jewish Historical Society of England 4 (1899): 177-93.

—. "The First English Jew: Notes on Antonio Ferdinando Carvajal, with Some Biographical Documents." Transactions of the Jewish Historical Society of England 2 (1894): 14-46.

-. "The Jewry of the Restoration." Transactions of the Jewish Historical Society of England 5 (1902): 5-33.

Woolf, Maurice. "Foreign Trade of London Jews in the Seventeenth Century." Transactions of the Jewish Historical Society of England 24 (1974): 38-58.

Wren, Christopher. "The Parochial Churches of Sir Christopher Wren, 1666-1718." In Publications, v. 9-10, edited by Arthur T Bolton and H Duncan Hendry. Oxford: Printed for the Wren Society at the University Press, 1932.

Yates, Nigel. Buildings, Faith, and Worship: The Liturgical Arrangement of Anglican Churches, 1600-1900. Oxford; New York: Oxford University Press, 2000.

Zakai, Avihu. "Thomas Brightman and English Apocalyptic Tradition.” In Menasseh Ben Israel and His World, 31-44, 1989. 


\section{Images}

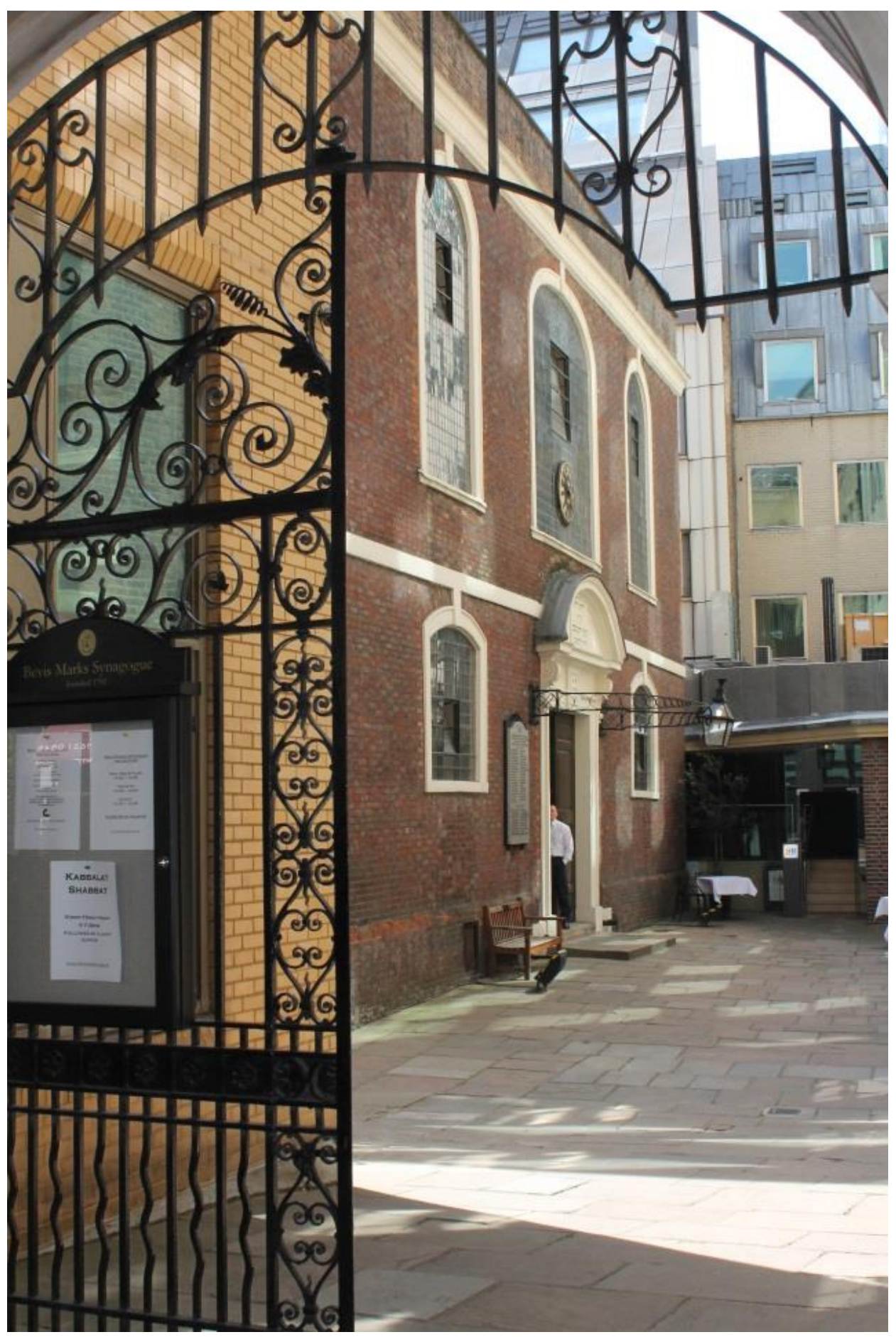

figure 1: Bevis Marks Synagogue, London. Main entrance and courtyard beyond gate.

(photo: author) 


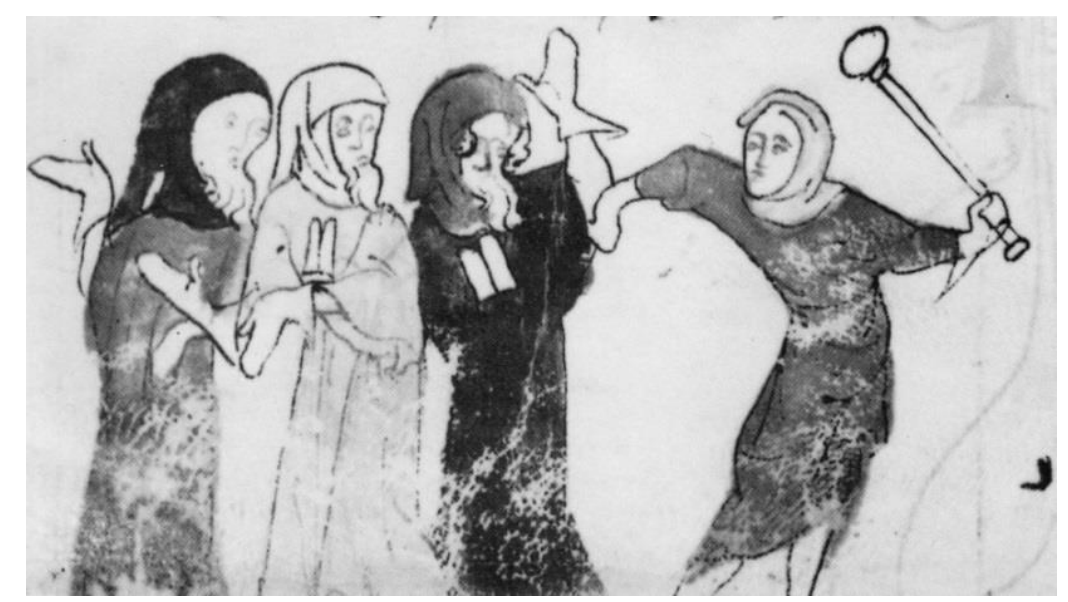

figure 2: Example of Jewish badge in England, in the shape of the Tablets of Law. Flores historiarum, England, early $14^{\text {th }}$ century. London, British Library MS. Cotton Nero D.ii, folio 183 verso (image: Mellinkoff, Ruth. Outcasts: Signs of Otherness in Northern European Art of the Late Middle Ages. Berkeley: University of California Press, 1993.

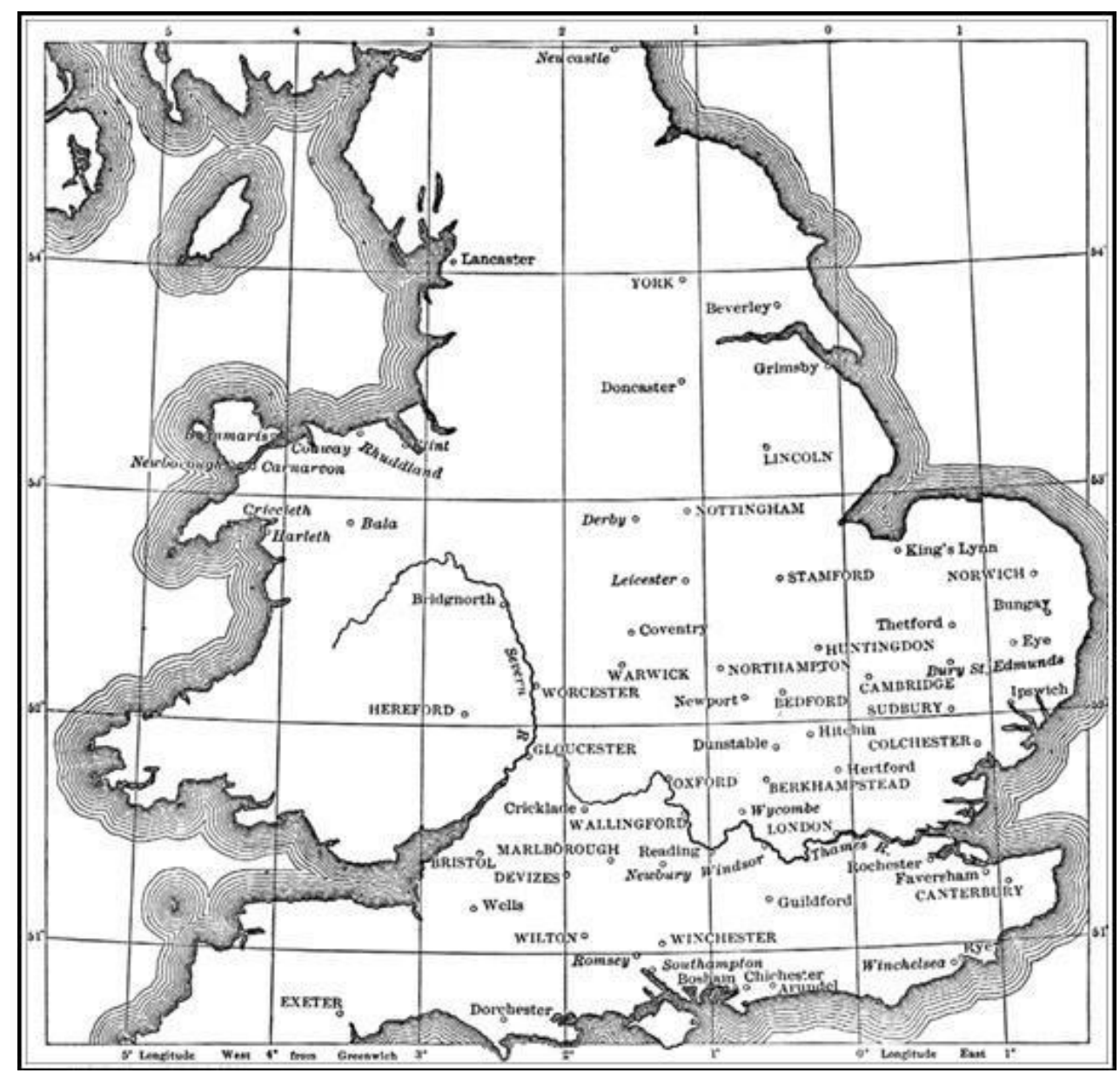

figure 3: Map of Locations of Jews in Medieval England before Expulsion in 1290, Capital letters indicate towns where archæ (all deeds, pledges, mortgages, lands, houses, rents, and possessions of registered Jews) were deposited; italics, towns from which Jews were expelled prior to 1290 (image: jewishencyclopedia.com) 


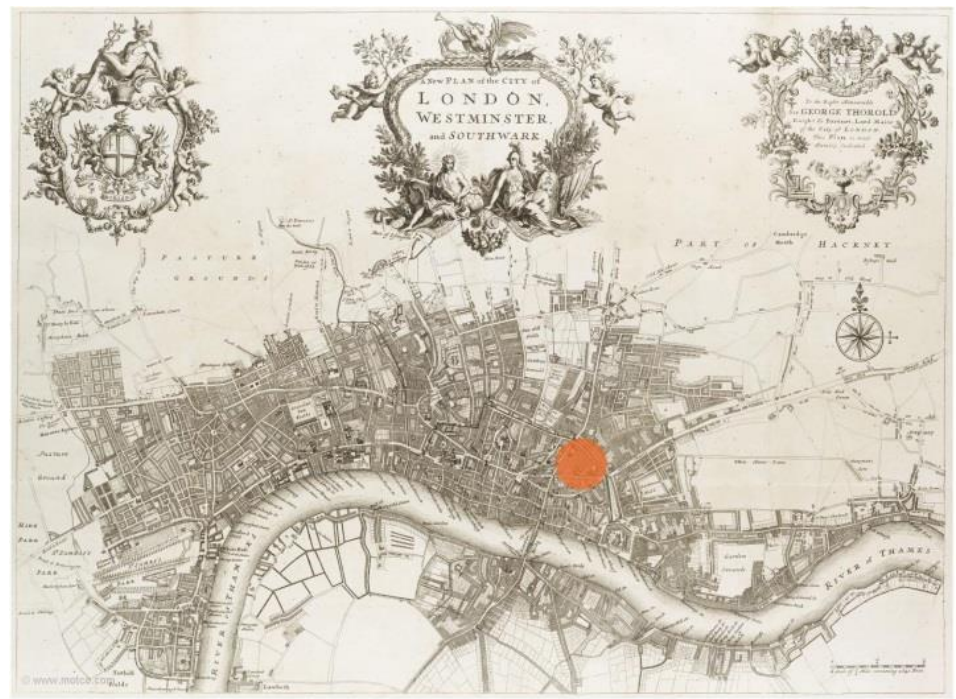

figure 4: Map of London, highlighted area gives the location of the mid to late-seventeenth century Jewish community. John Strype, Survey of London, published in 1720 (image: http://www.hrionline.ac.uk/strype/)

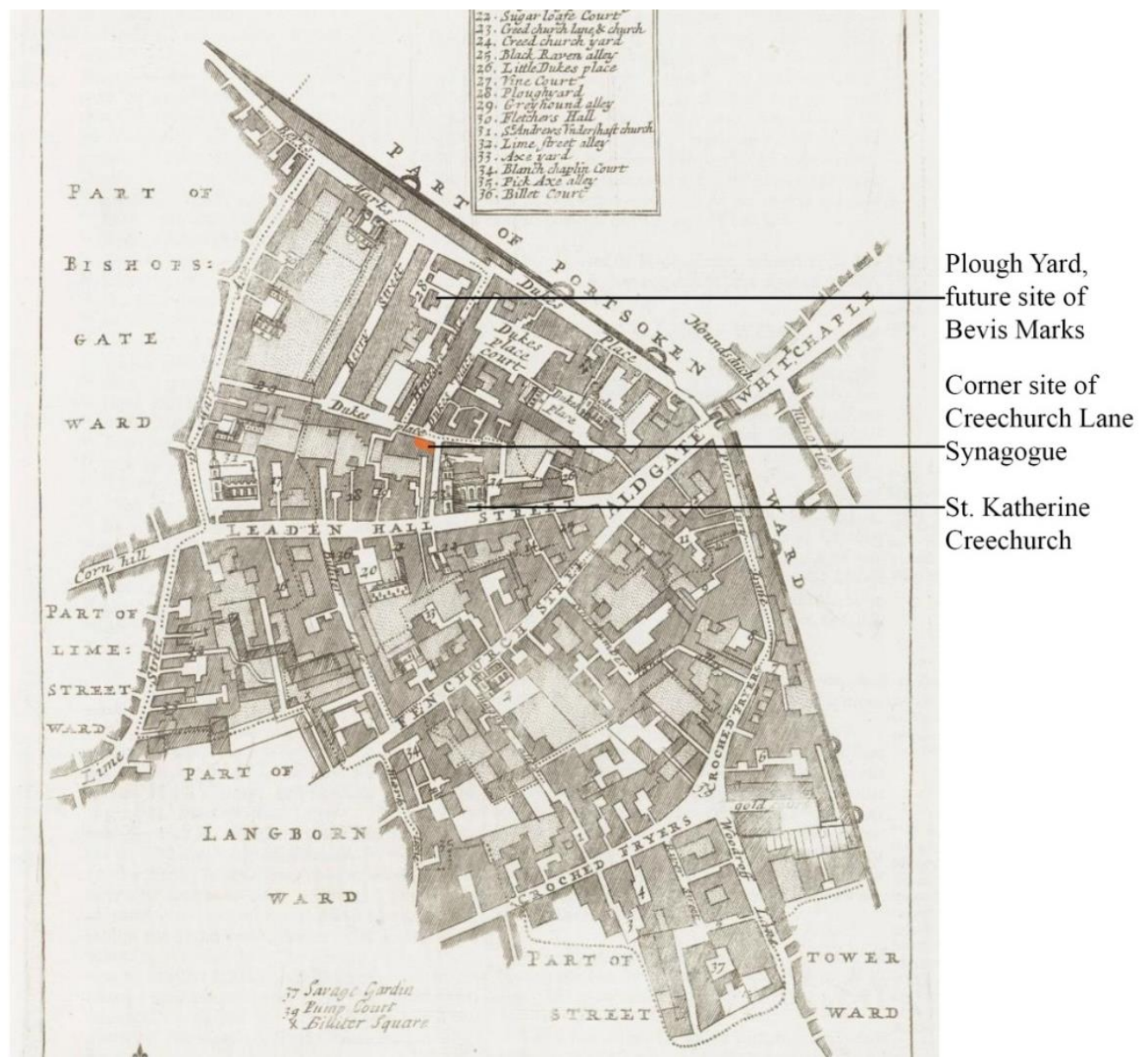

figure 5: Aldgate Ward, London. Spanish and Portuguese Jewish neighborhood, mid to lateseventeenth century. Key buildings highlighted. (image: John Strype's Survey of London, http://www.hrionline.ac.uk/strype/) 


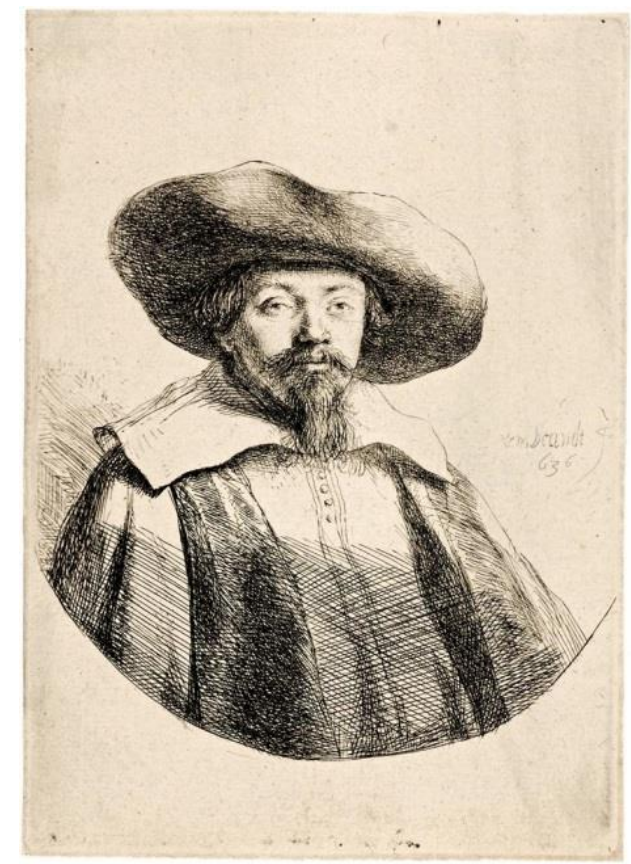

figure 6: Portrait of Menasseh ben Israel by Rembrandt, 1654

(image: Wikimedia Commons)

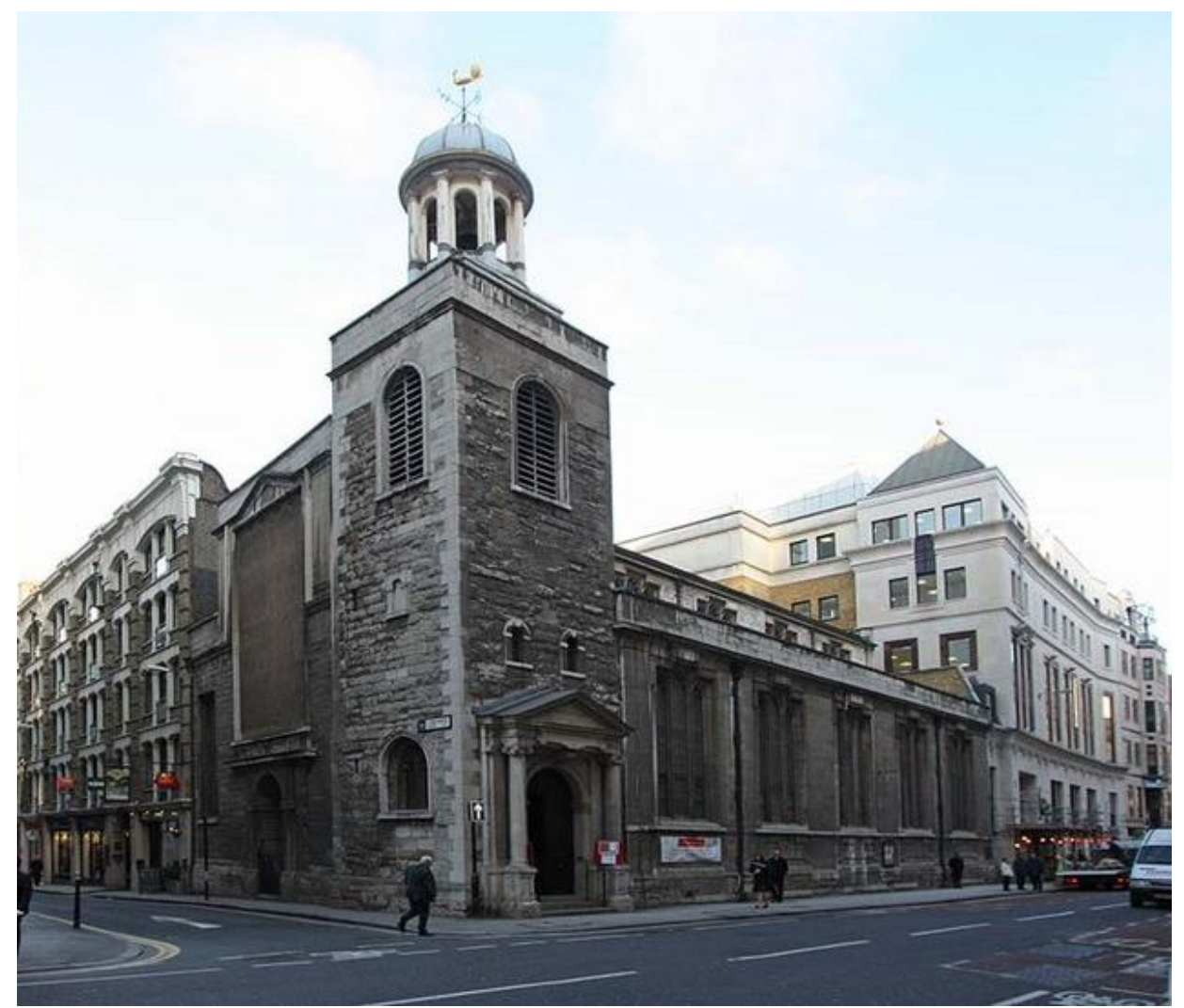

figure 7: St. Katherine Creechurch, London (image: Wikimedia Commons) 


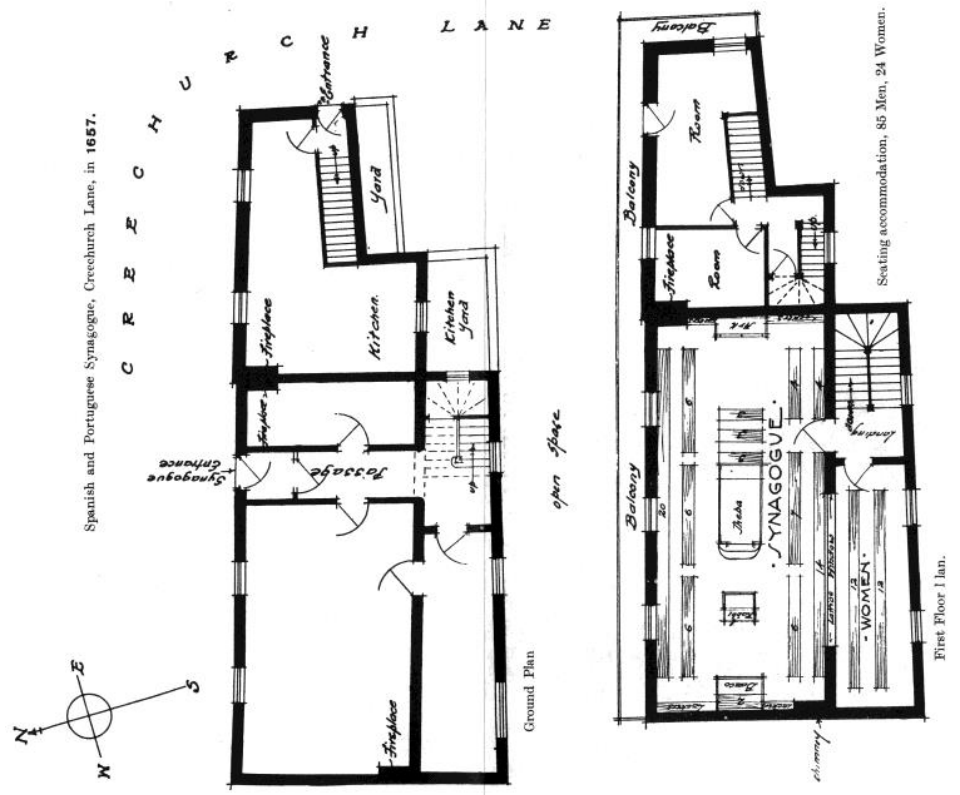

figure 8: Creechurch Lane Synagogue, London. Floor Plans, 1657. Reconstructed from evidence found in various documents and drawn by Manuel N. Castello, A.R.I.B.A. (image: Samuel, Wilfred S. "The First London Synagogue of the Resettlement [Creechurch Lane]." Transactions of the Jewish Historical Society of England 10 (1924): 1-147.)

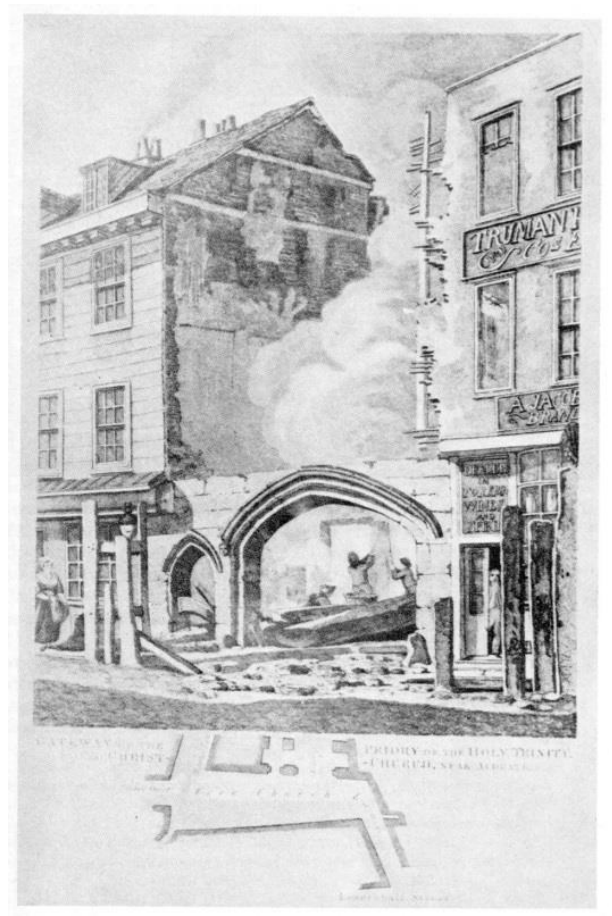

figure 9: The Great Gate leading into Duke's Place, Aldgate Ward, London. A print from 1825 showing its demolition 1816, after having stood since 1280. (image: Samuel, 1924) 

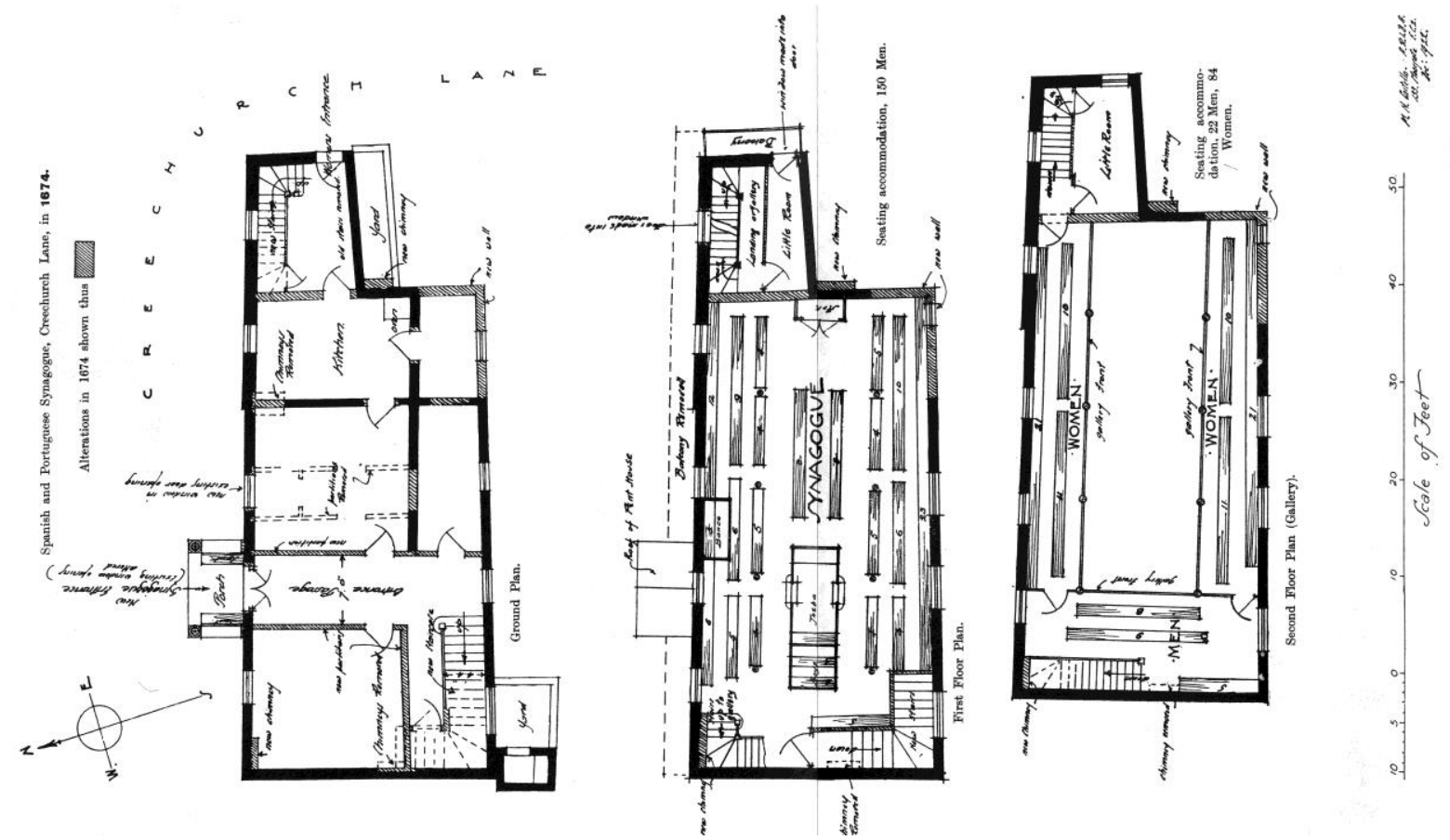

figure 10: Creechurch Lane Synagogue, London. Floor Plans after remodel in 1674.

Reconstructed from evidence found in various documents and drawn by Manuel N. Castello, A.R.I.B.A. (image: Samuel, 1924)

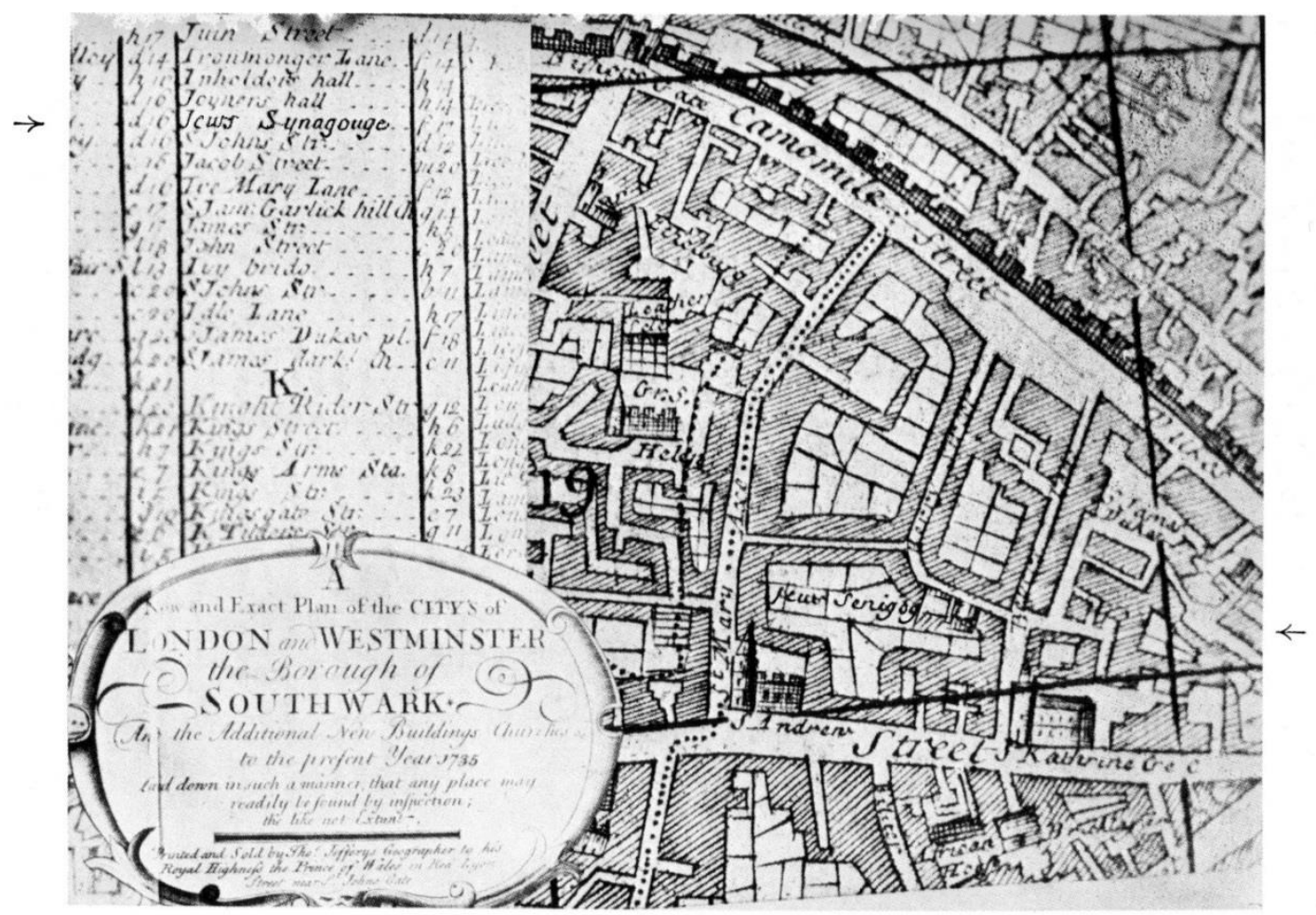

figure 11: The 'Jews Synagogue' as a 'Place of Interest' in London, see arrows. Composite image from a map printed in 1735 , but based on the $17^{\text {th }}$ century survey of Thomas Jeffreys (image: Samuel, 1924) 


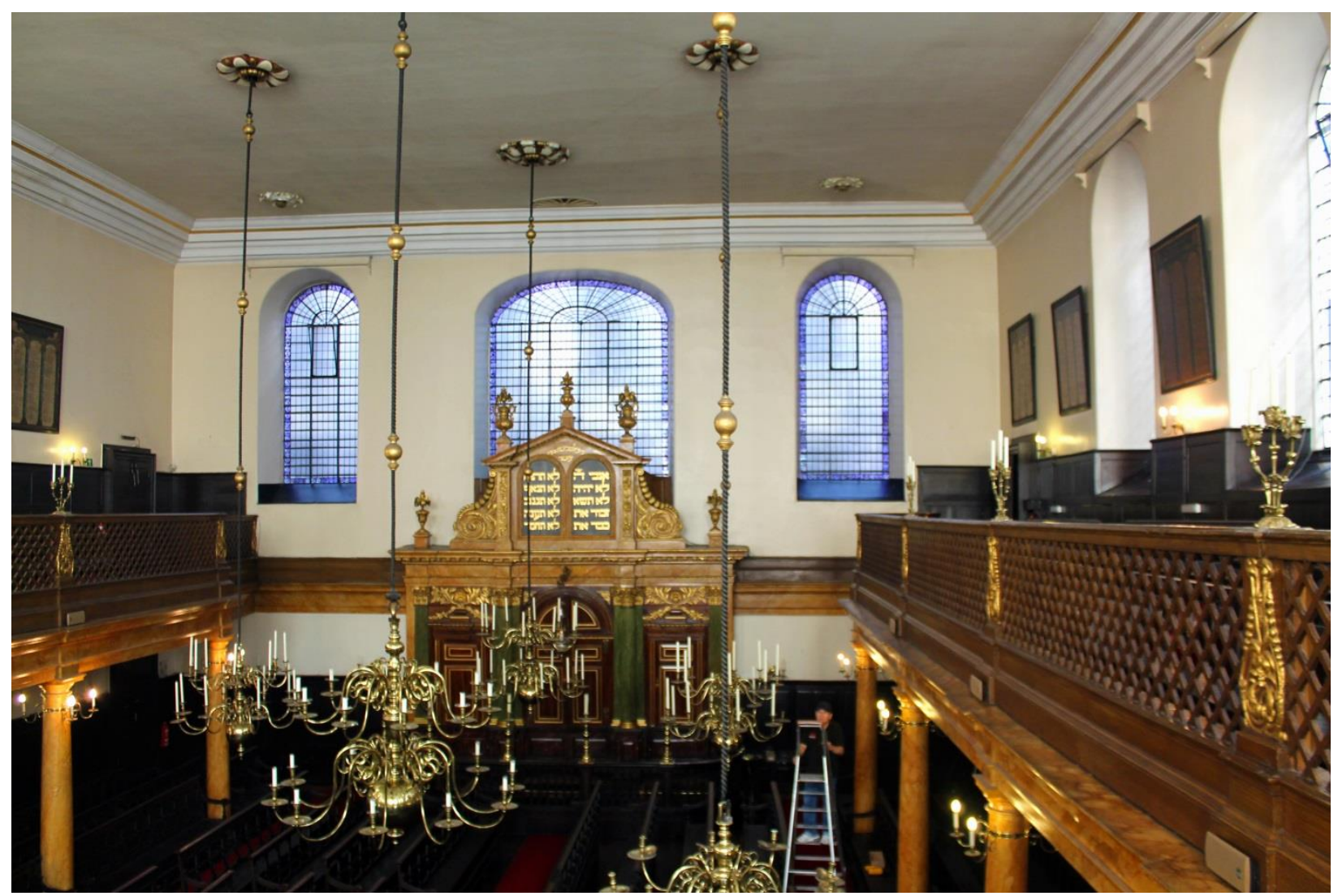

figure 12: Bevis Marks Synagogue, London. East interior view towards Ark (Echal). (image: author)

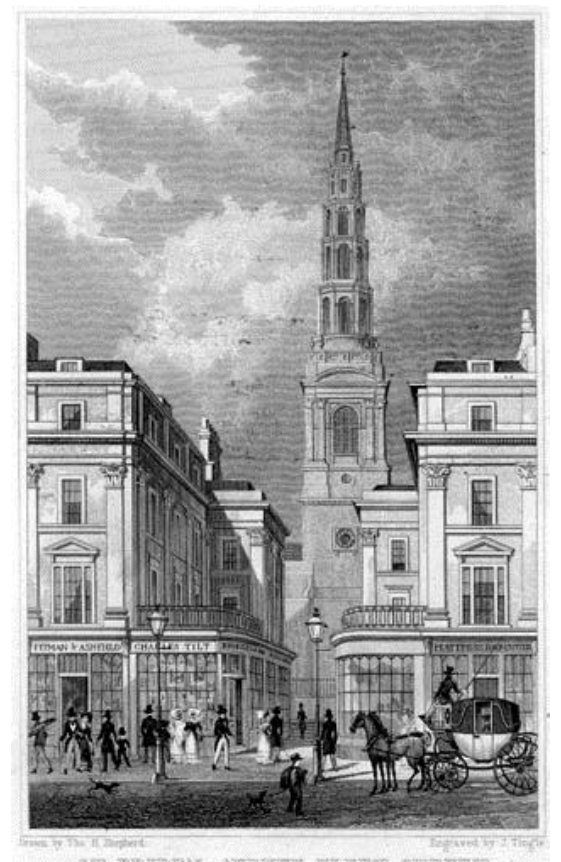

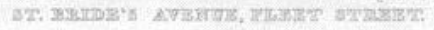

figure 13: St Bride's Fleet Street, London. Street view (image: Wikimedia Commons) 


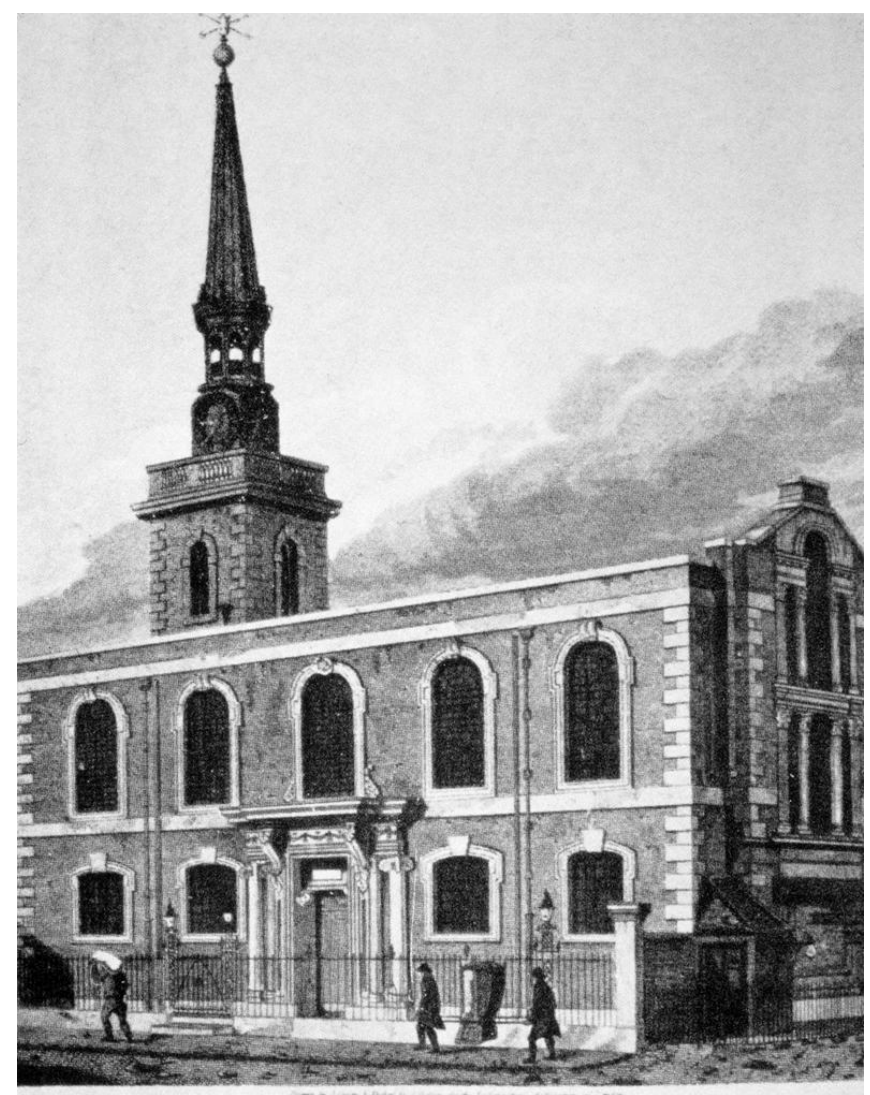

figure 14: St. James Piccadilly, London. Exterior circa 1815 (image: Wikimedia Commons)

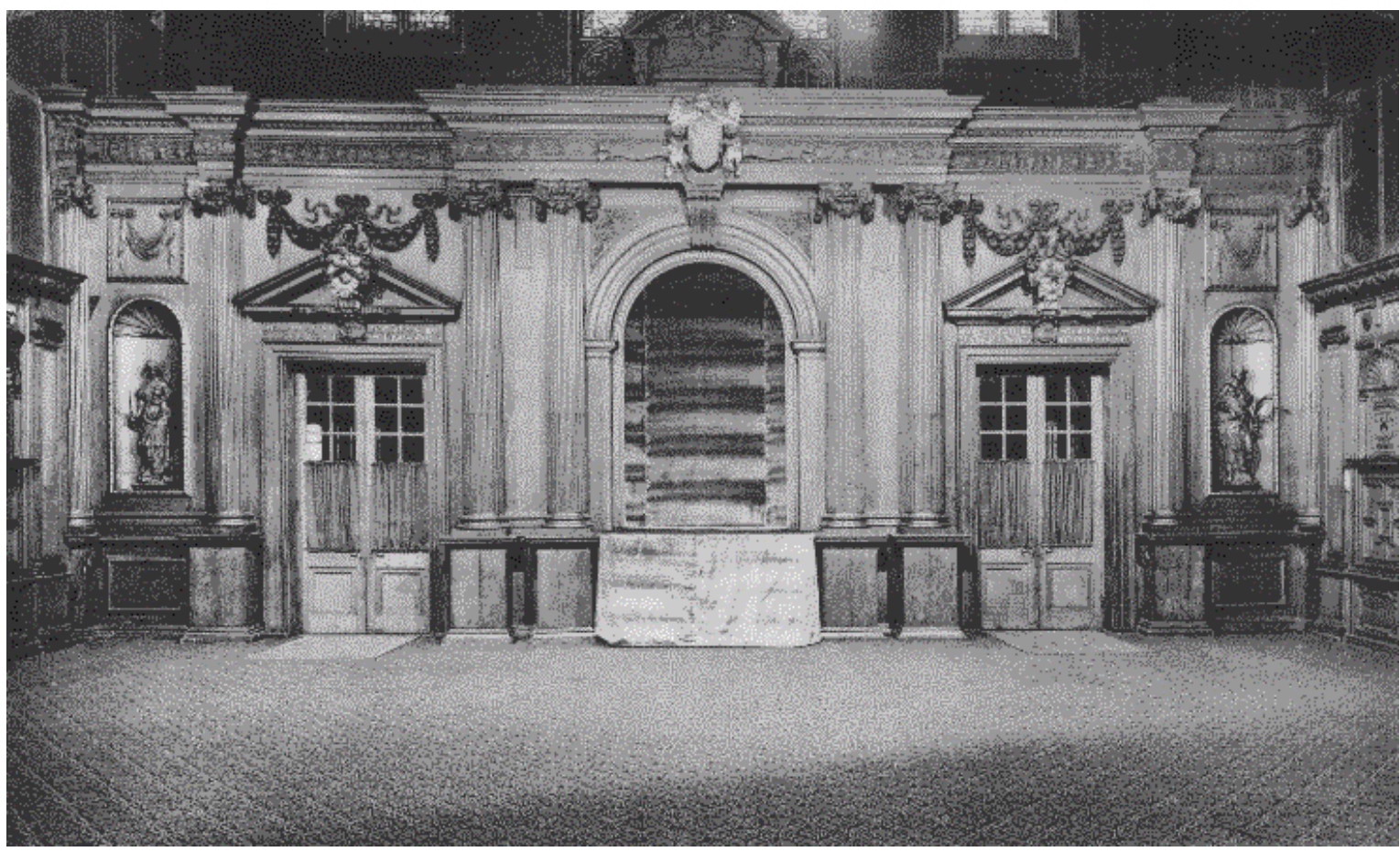

figure 15: Merchant Taylors' Hall, London. Entry way designed by Joseph Avis for Robert Hooke. Destroyed during WWII. (image: http://www.roberthooke.org.uk/) 


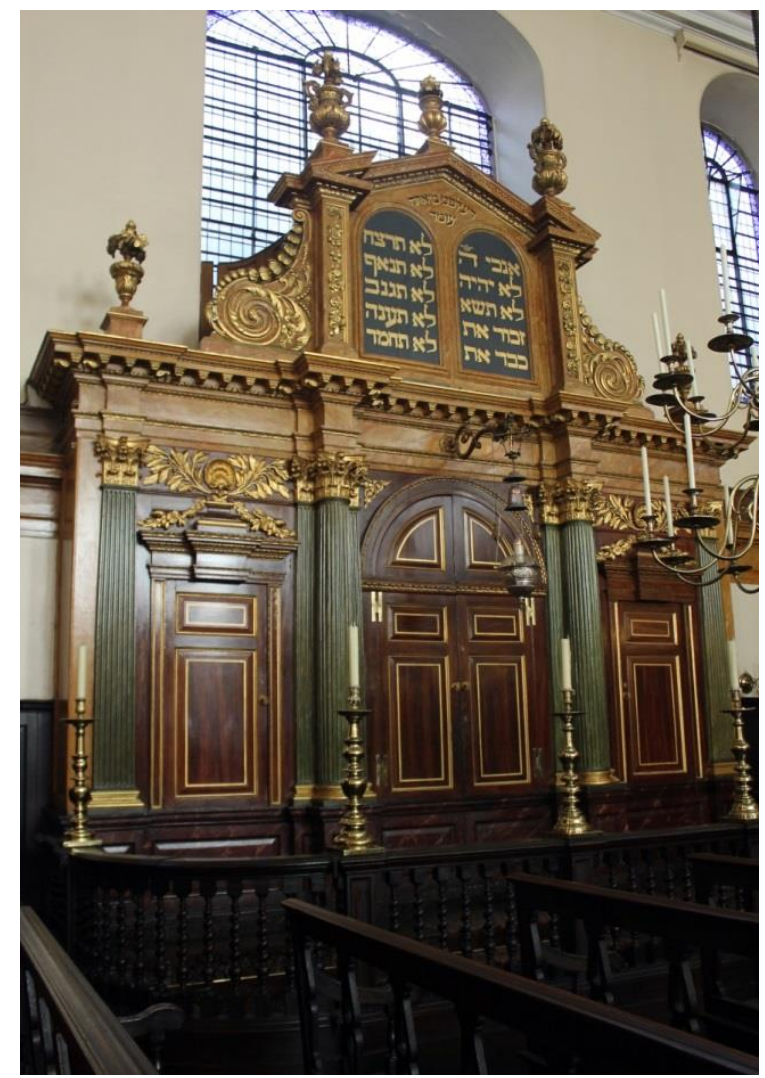

figure 16: Bevis Marks Synagogue, London. Ark (Echal) (image: author)

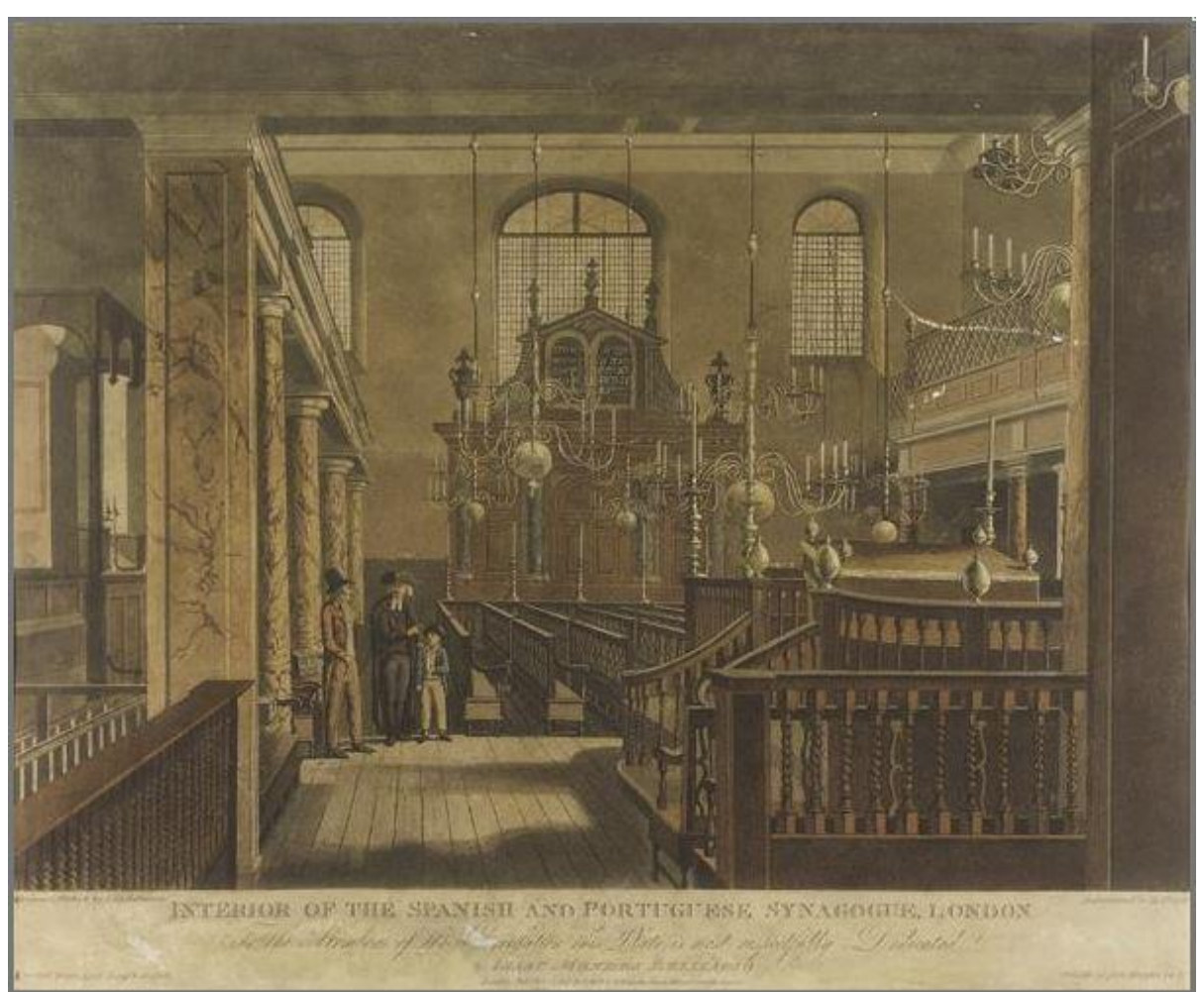

figure 17: Bevis Marks Synagogue, London. Drawing of interior by M. Bellisario, late $18^{\text {th }} \mathrm{c}$. (image: http://www.jewishmuseum.org.uk/) 


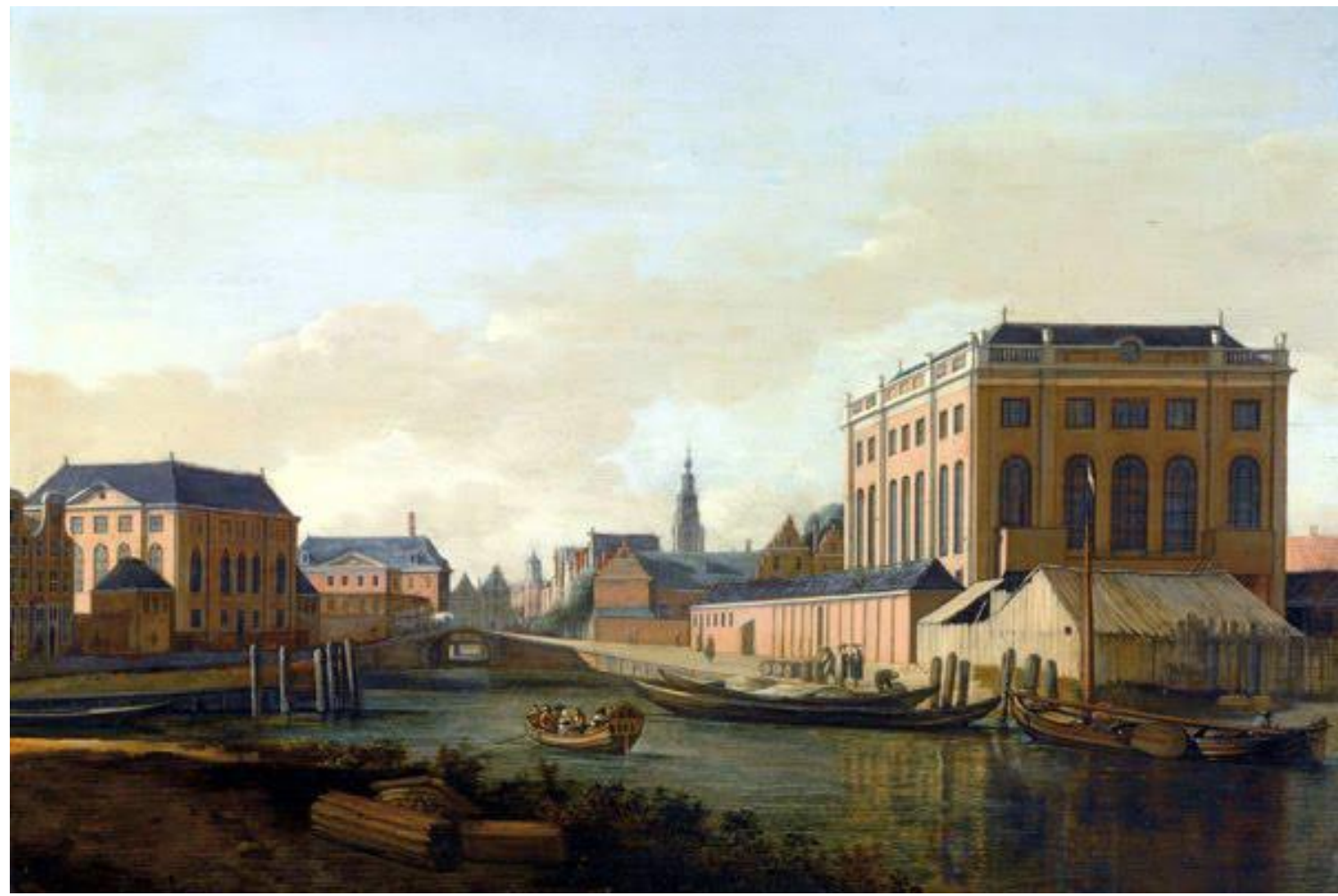

figure 18: The Spanish and Portuguese Synagogue (Esnoga), Amsterdam. Exterior view across canal (synagogue on right). Oil painting by Gerrit Adriaensz Berckheyde (Haarlem 1638-1698), Amsterdam: view of the Portuguese and the Grote Synagogues. (image: Wikimedia Commons)

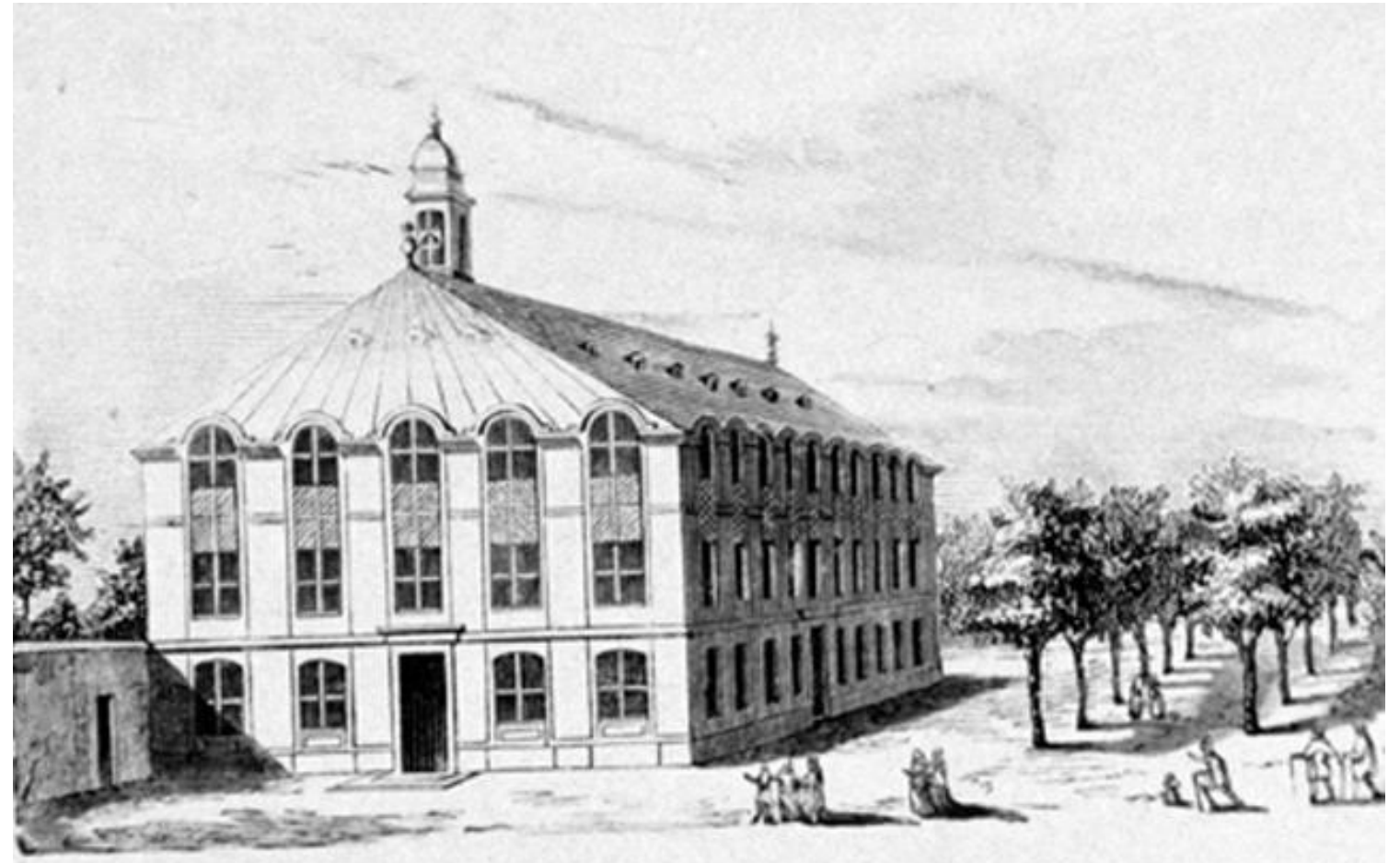

figure 19: Temple at Charenton, France. Exterior view. Built 1623 by architect Solomon de Brosse, demolished 1685. (image: http://museeprotestant.org/) 


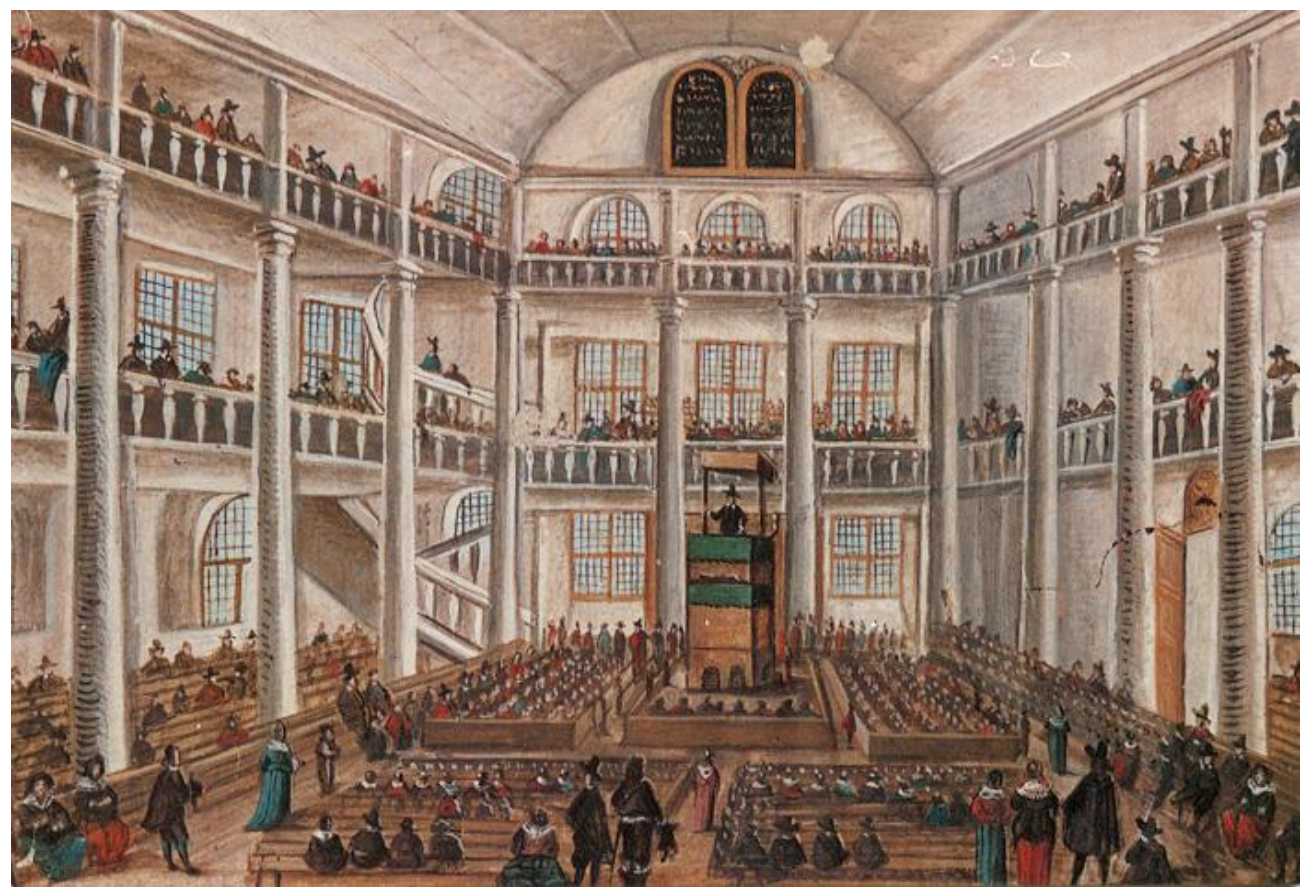

figure 20: Temple at Charenton, France. Interior view. (image: http://museeprotestant.org/)

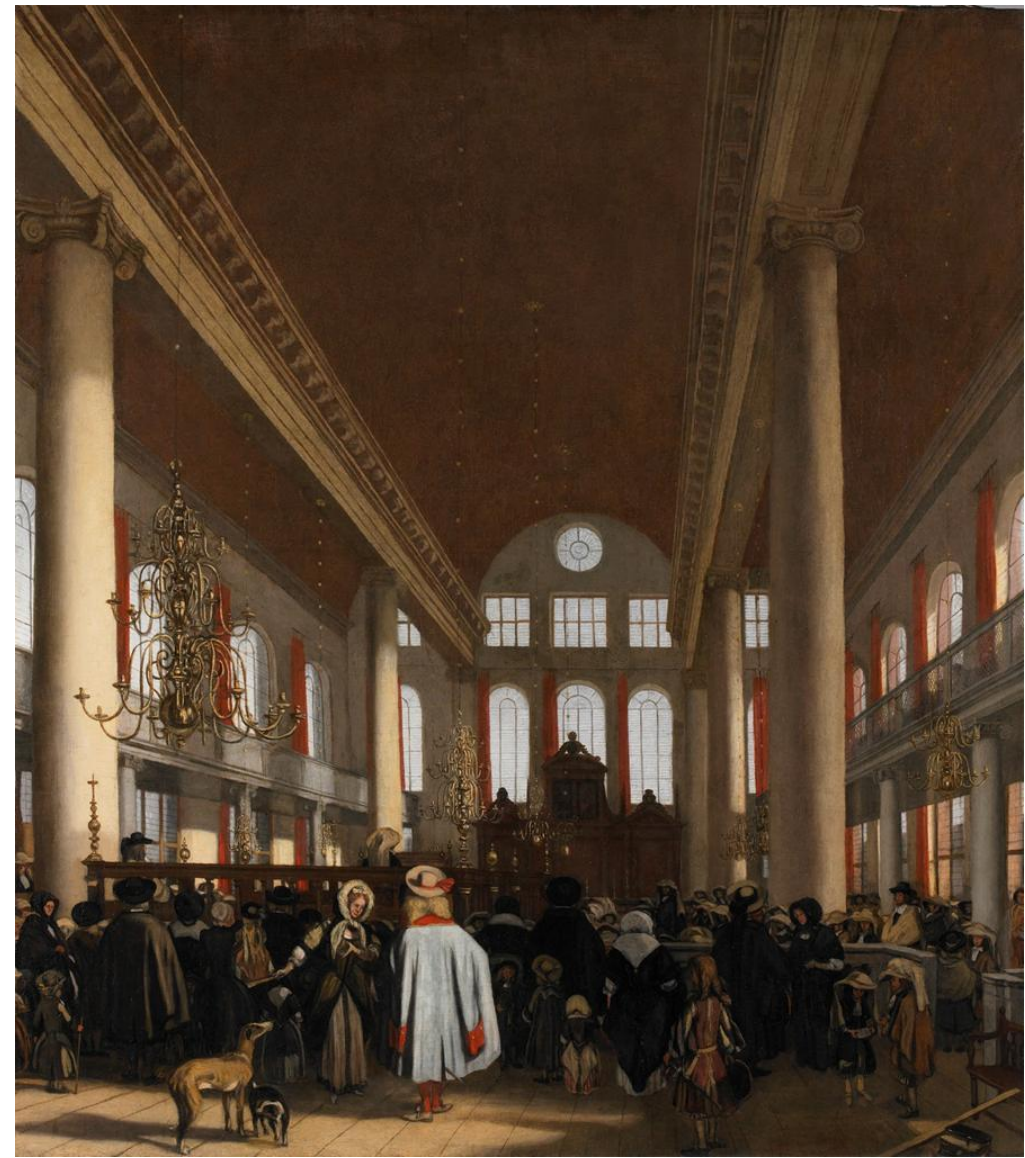

figure 21: Spanish and Portuguese Synagogue (Esnoga), Amsterdam. Interior of the Portuguese Synagogue, Emanuel de Witte (1617-1692), oil painting, 1680 (image: Wikimedia Commons) 


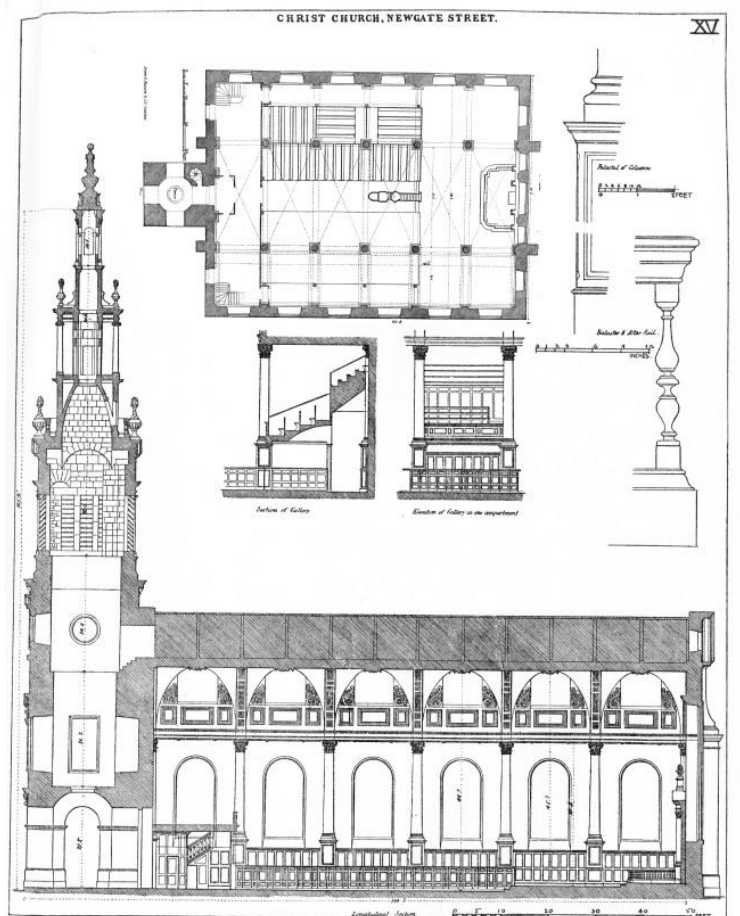

figure 22: Christ Church New Gate, London. Plan, longitudinal section (image: Wren, Christopher. "The Parochial Churches of Sir Christopher Wren, 1666-1718." In Publications, $v$. 9-10, edited by Arthur T Bolton and H Duncan Hendry. Oxford: Printed for the Wren Society at the University Press, 1932.)

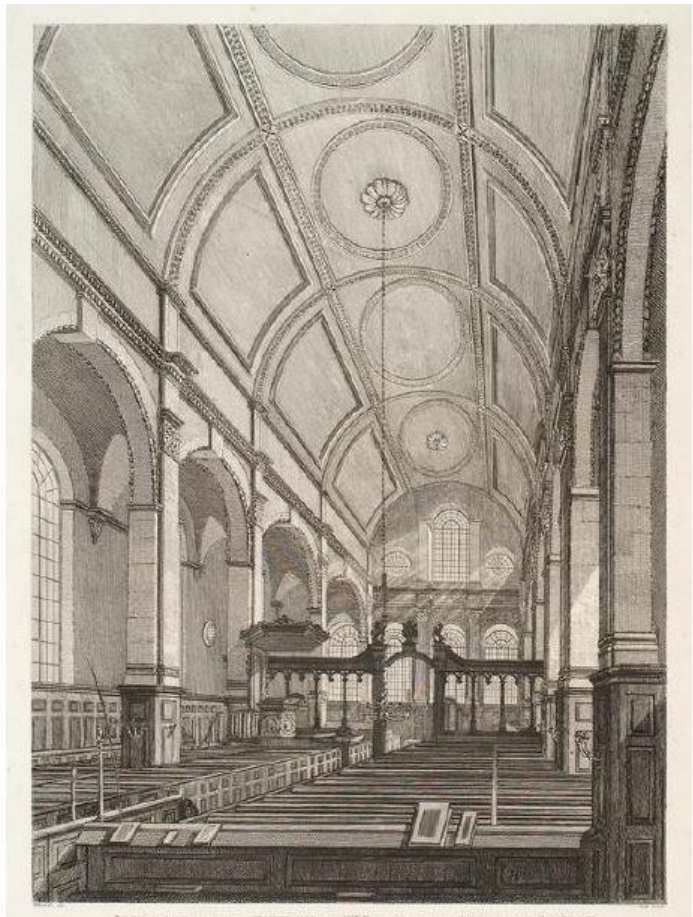

figure 23: St Peter, Cornhill, London. Engraving circa 1820-30 (image: http://christchurchartgallery.org.nz/) 


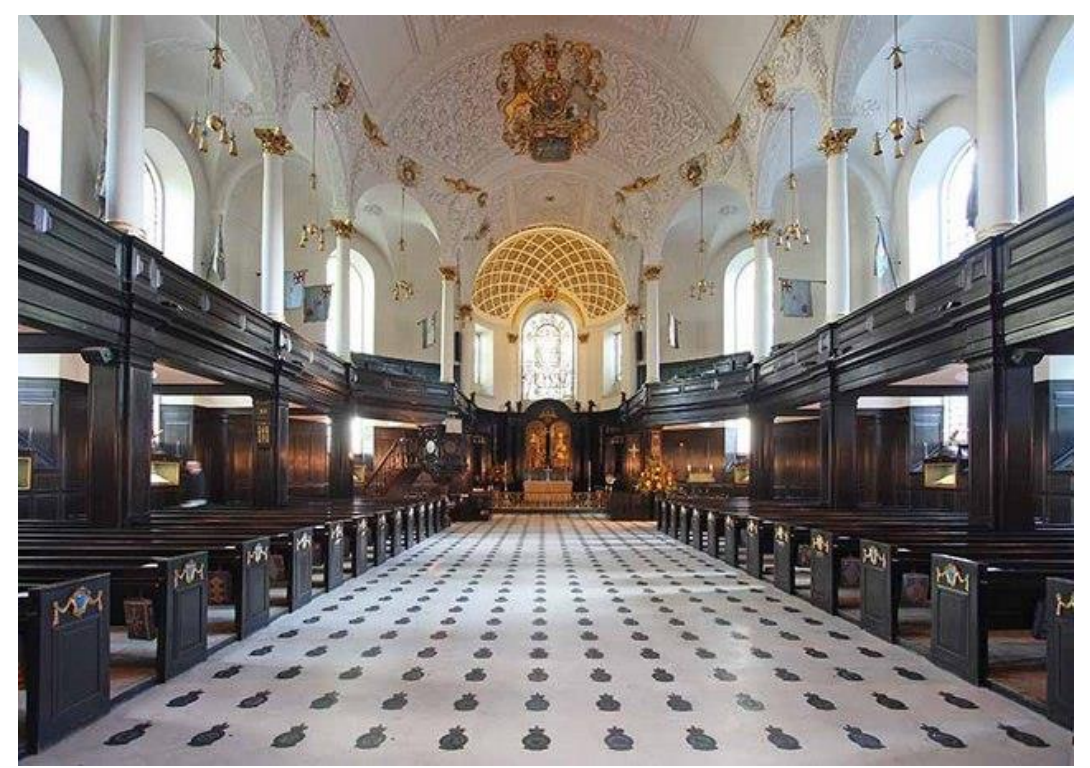

figure 24: St Clement Dames in the Strand, London. Modern interior view towards alter (reconstructed after WWII damage). (image: Wikimedia Commons)

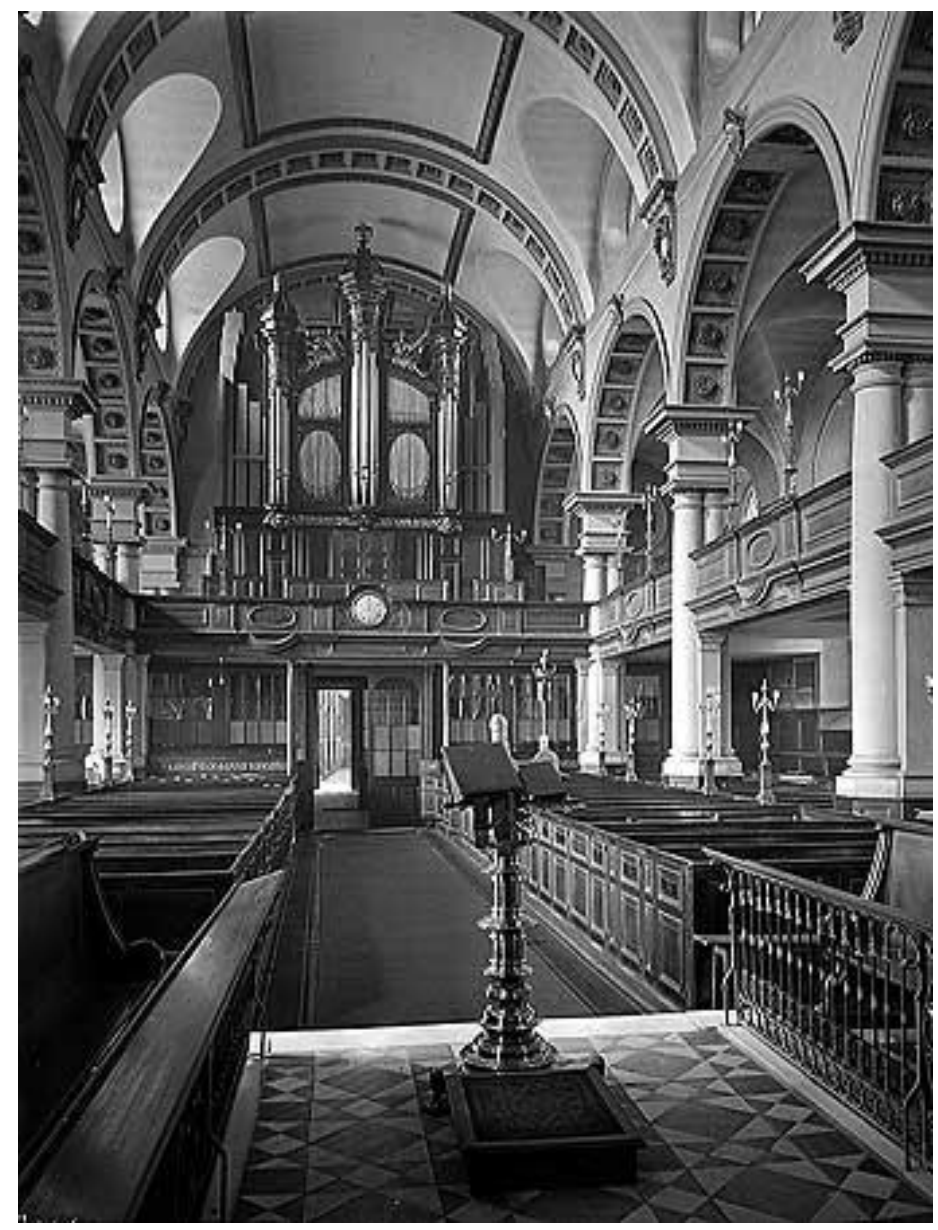

figure 25: St Bride's, Fleet Street, London. Interior view, west towards Organ. Photo taken circa 1920, before damage from WWII. Photographer: S O Gorse (image: http://viewfinder.englishheritage.org.uk/) 


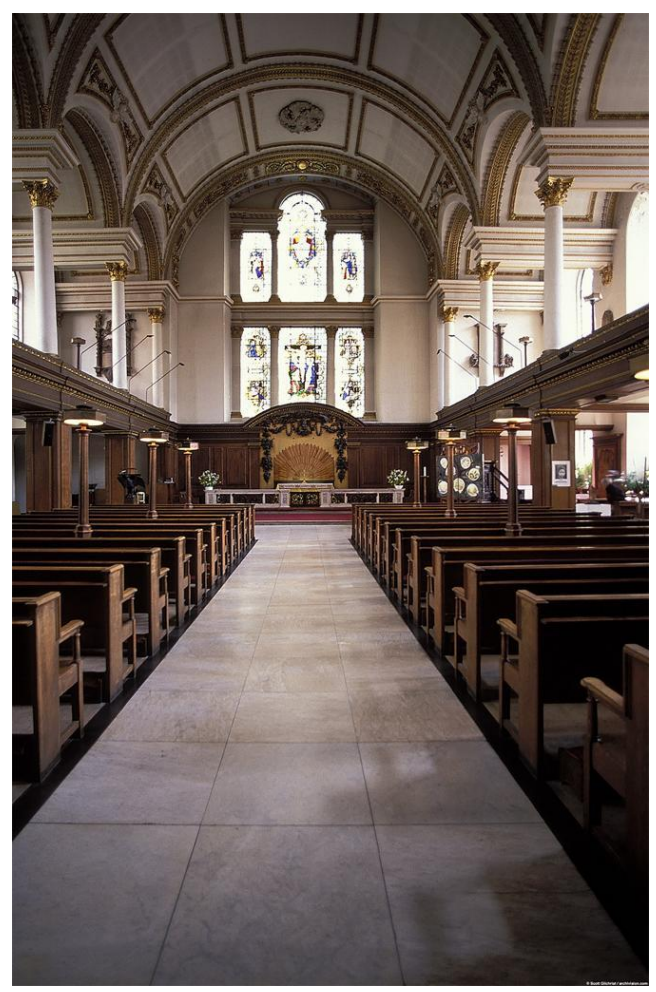

figure 26: St James Piccadilly, London. Modern interior view towards east end and alter (reconstructed after WWII damage). (image: Wikipedia Commons)

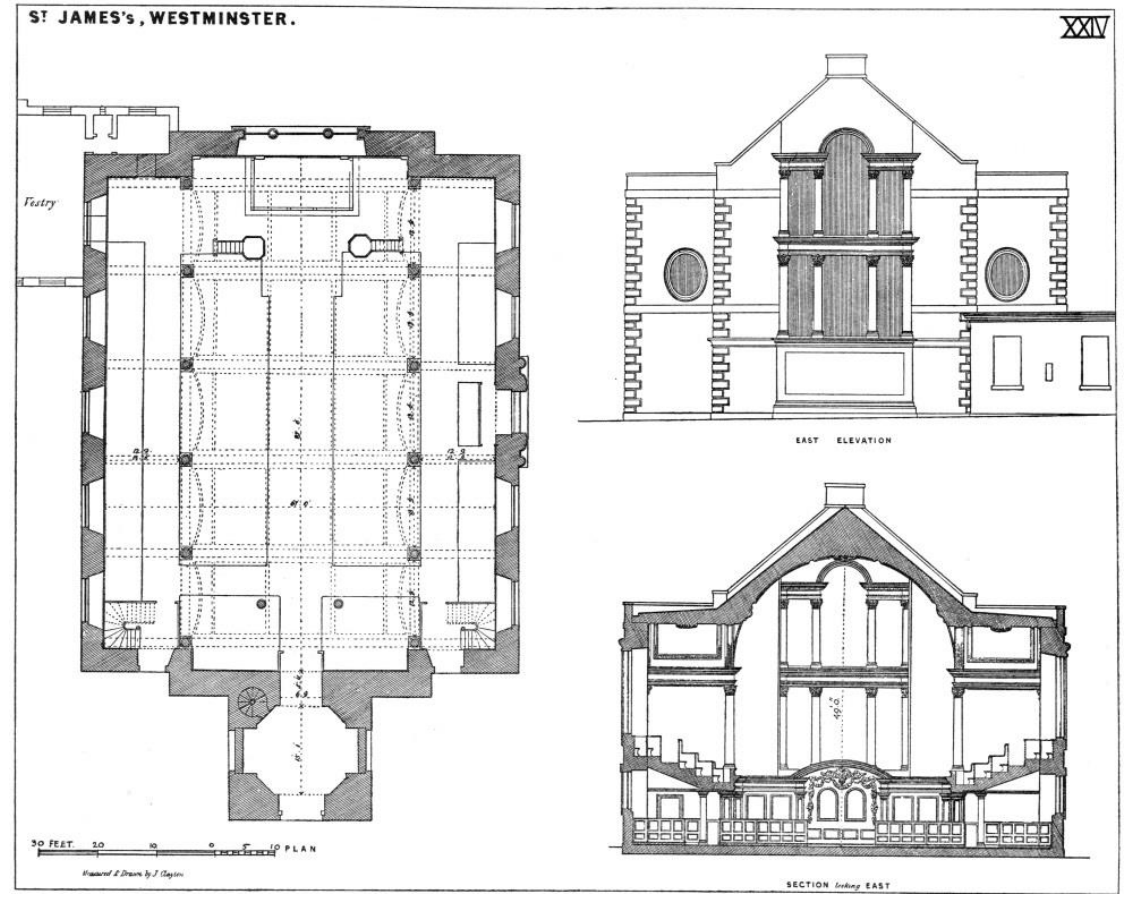

figure 27: St. James Piccadilly, London. Plan, east exterior and interior elevations. (image: Wren, Christopher. "The Parochial Churches of Sir Christopher Wren, 1666-1718." In Publications, $v$. 9-10, edited by Arthur T Bolton and H Duncan Hendry. Oxford: Printed for the Wren Society at the University Press, 1932.) 


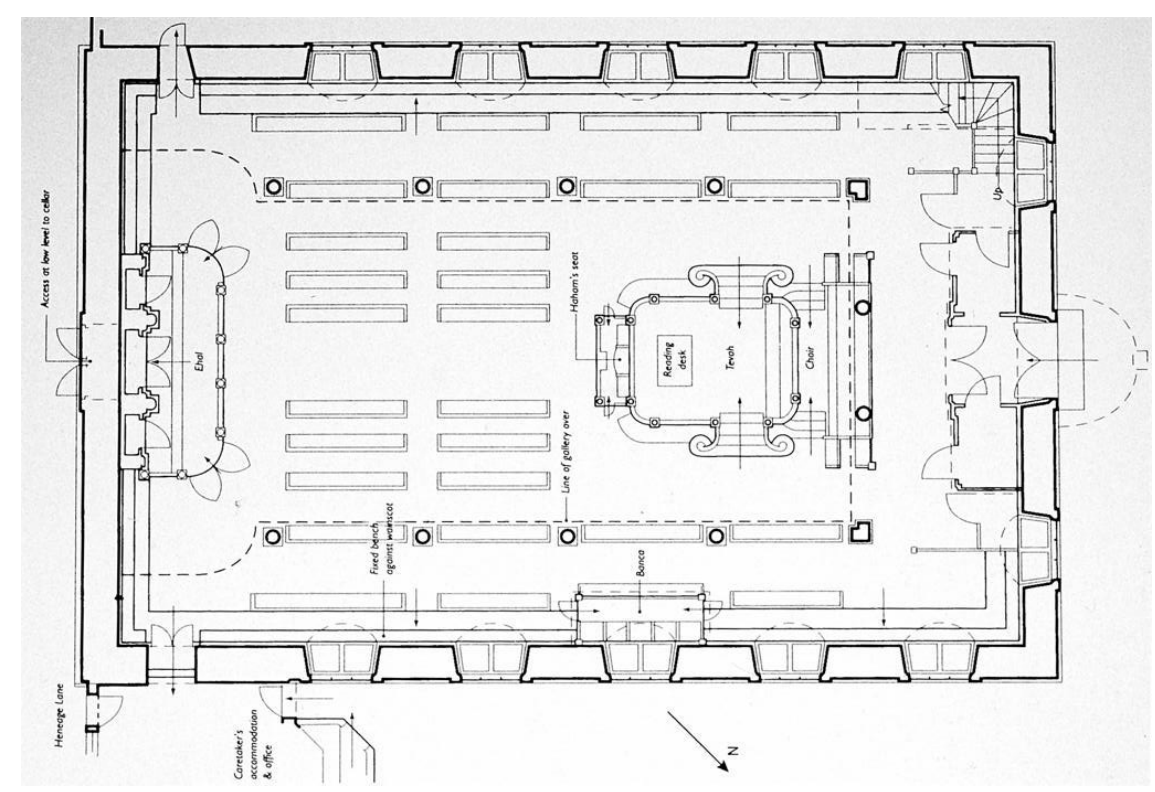

figure 28: Bevis Marks Synagogue, London. Ground floor plan. Based on drawing by Barbara Bowman, published in Kadish, Sharman. Bevis Marks Synagogue: A Short History of the Building and an Appreciation of Its Architecture. Swindon: English Heritage, 2002.

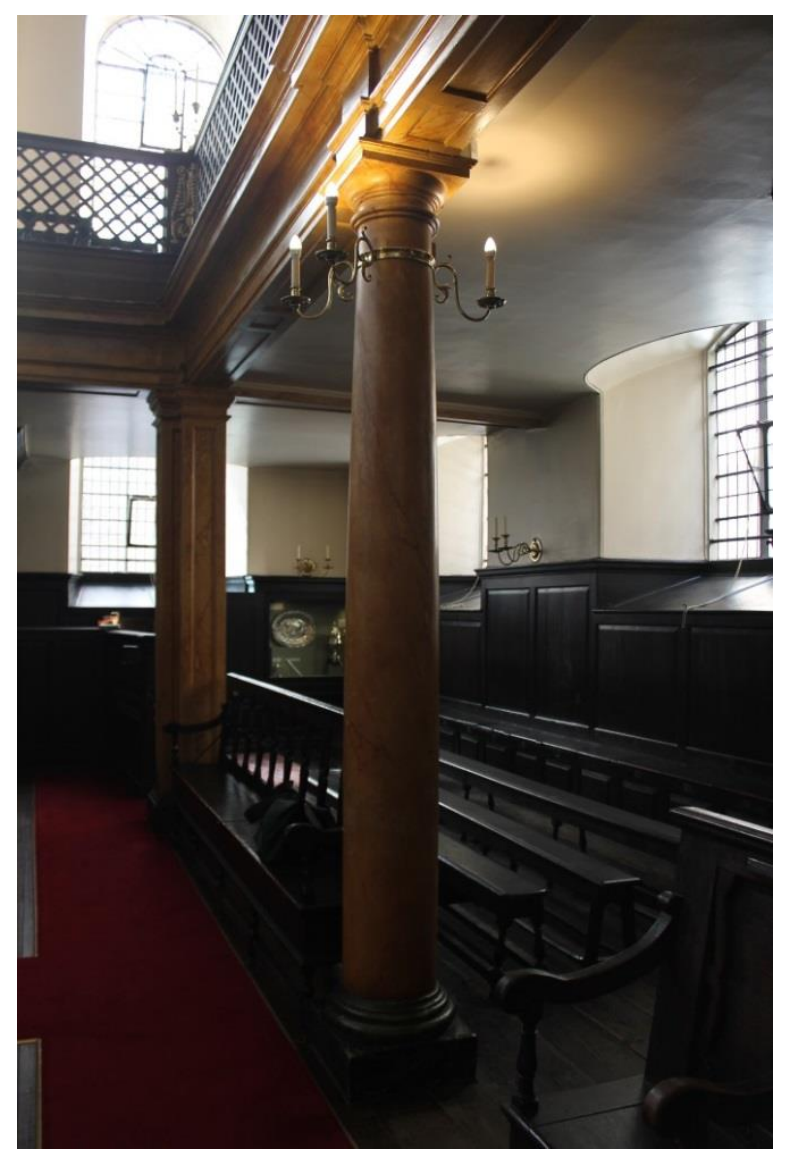

figure 29: Bevis Marks Synagogue, London. Interior, detail of columns and wainscoting. Benches in view originally constructed for Creechurch Lane and brought to Bevis Marks. (image: author) 


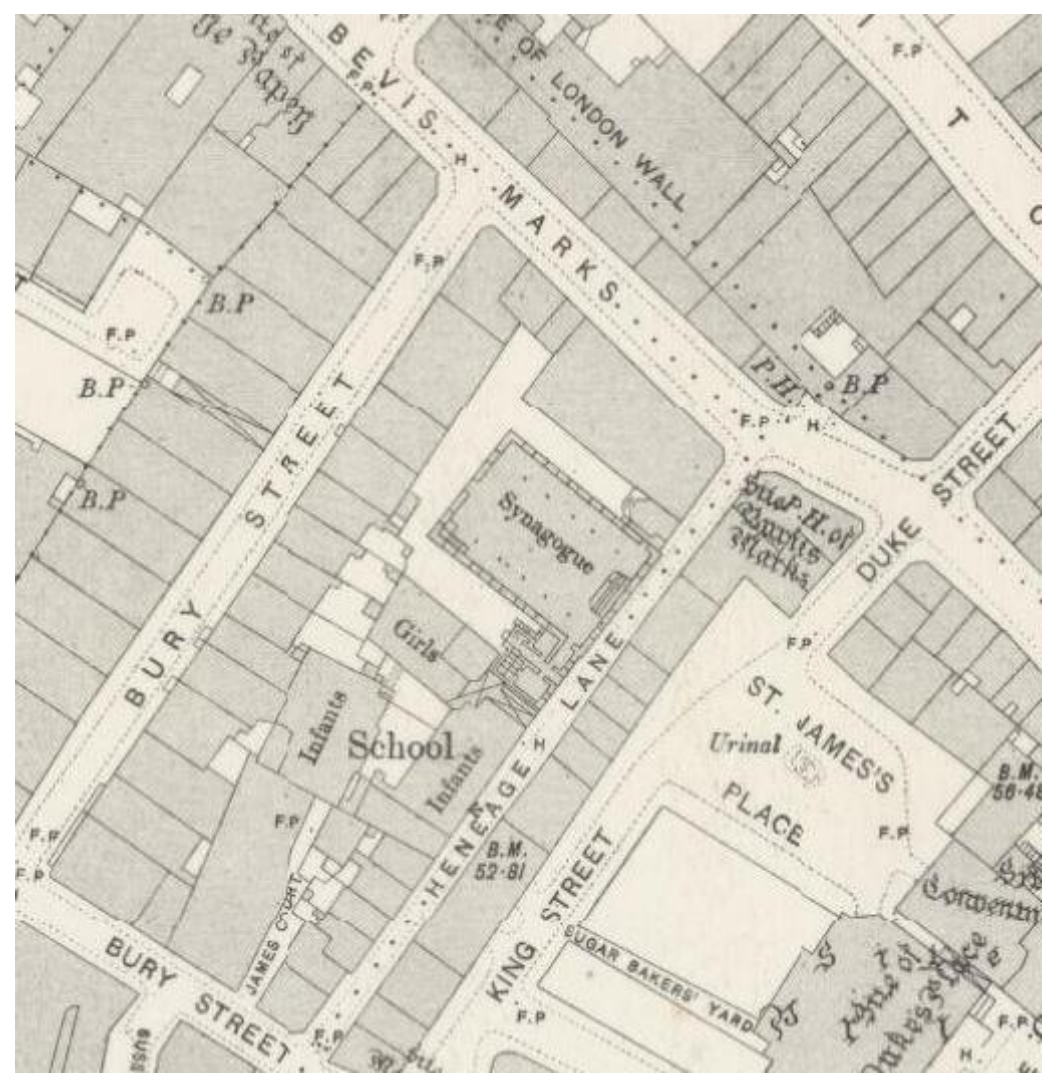

figure 30: Bevis Marks Synagogue, London. Site plan from 1896 “ordnance Survey” map of synagogue area. From sheet VII- 66. (image: http://maps.nls.uk/)

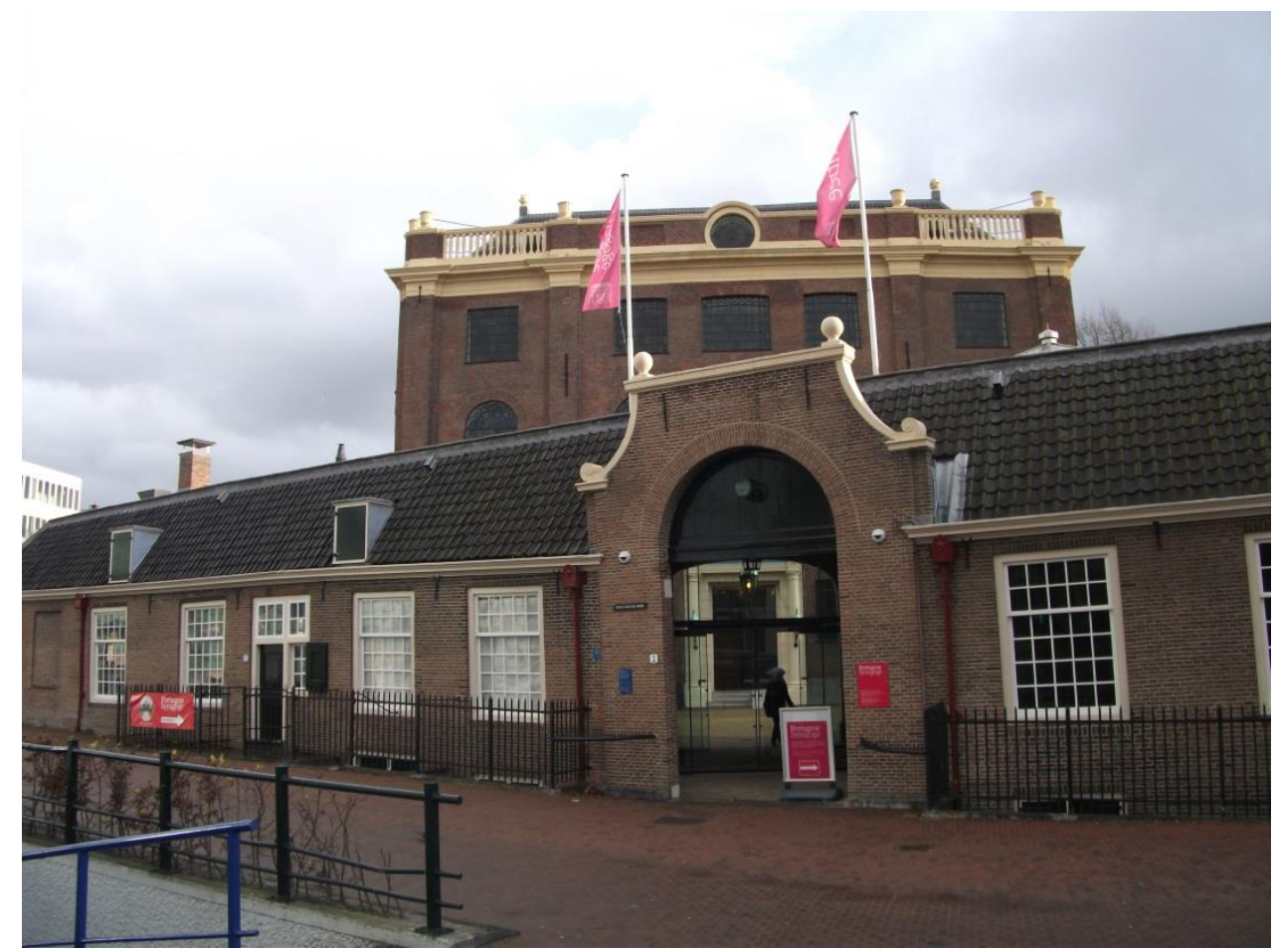

figure 31: The Spanish and Portuguese Synagogue (Esnoga), Amsterdam. Modern exterior street view. (image: Wikimedia Commons) 


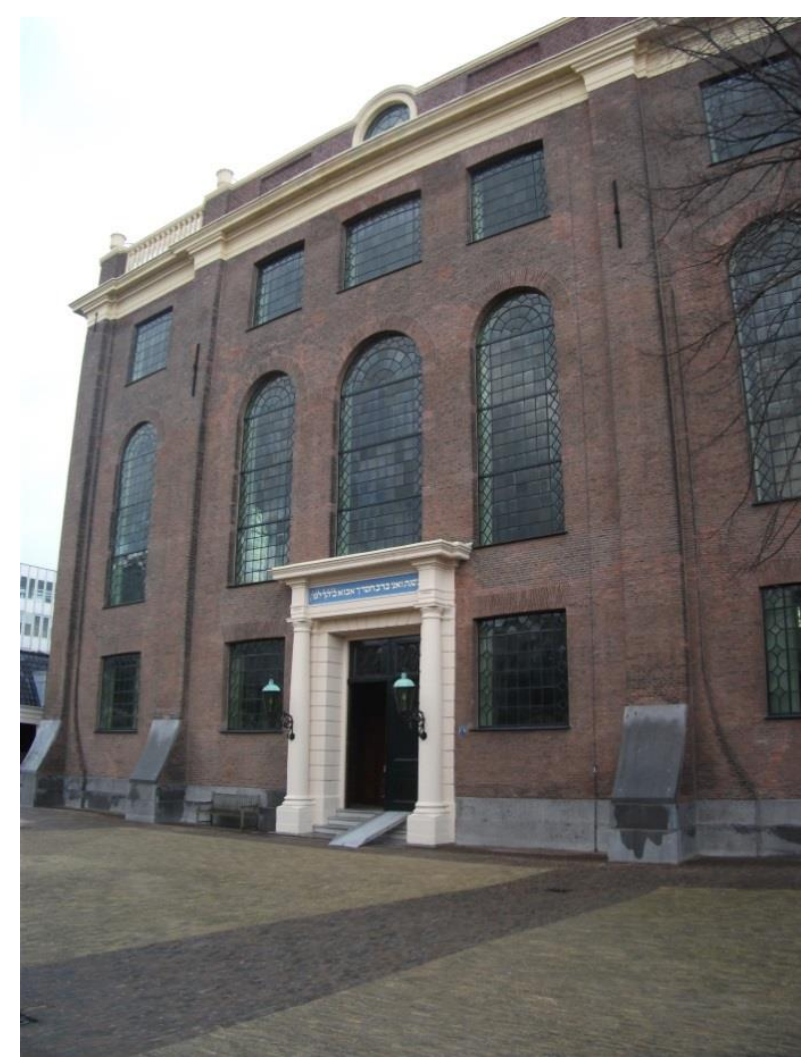

figure 32: The Spanish and Portuguese Synagogue (Esnoga), Amsterdam. Main entrance and elevation (image: Wikipedia Commons)

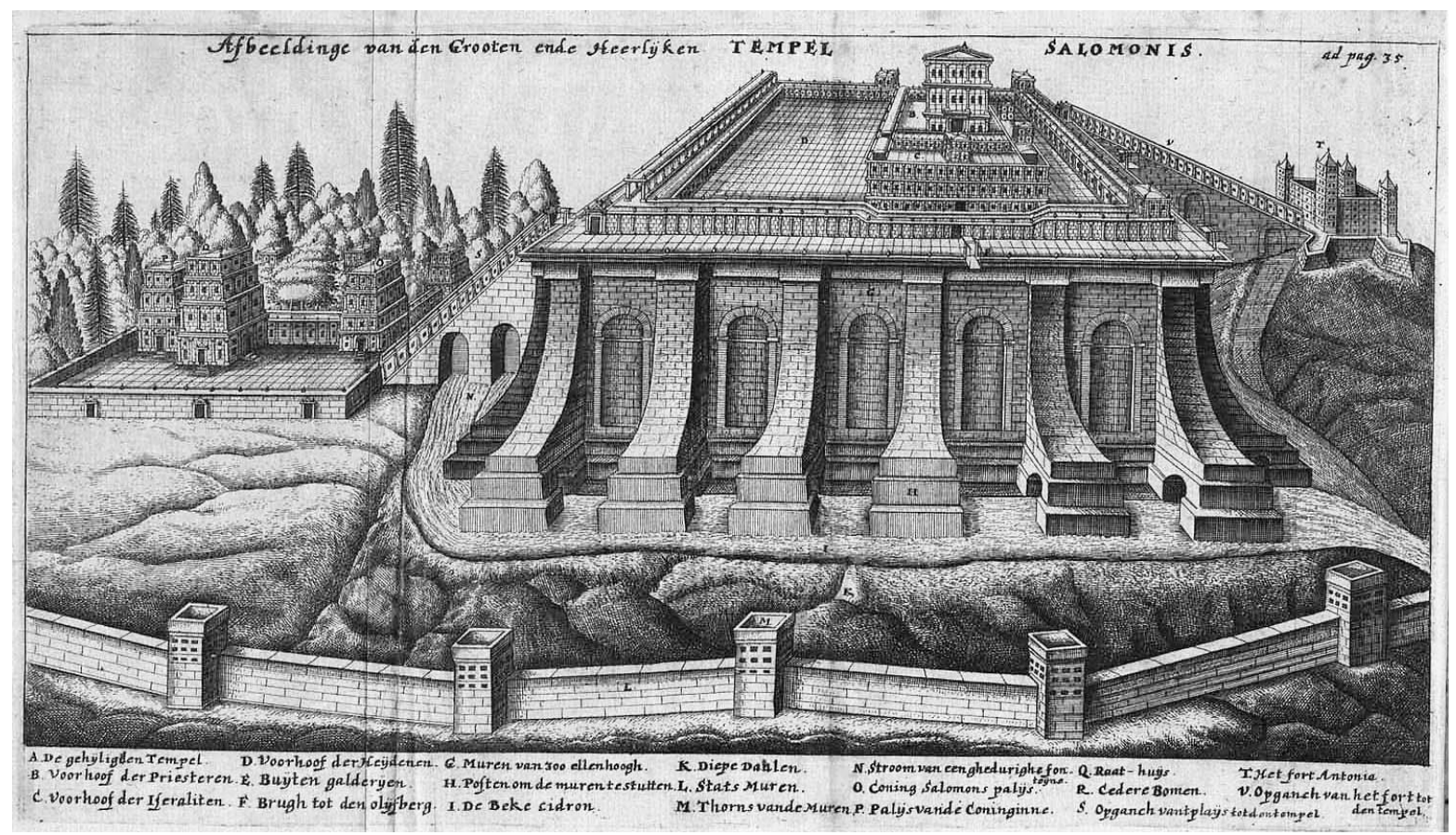

figure 33: Depiction of Solomon's Temple complex, engraving from an edition of Jacob Judah Leon's Afbeelding van den Tempel Salomonis, Amsterdam, 1644 (image: http://www.mhs.ox.ac.uk/) 


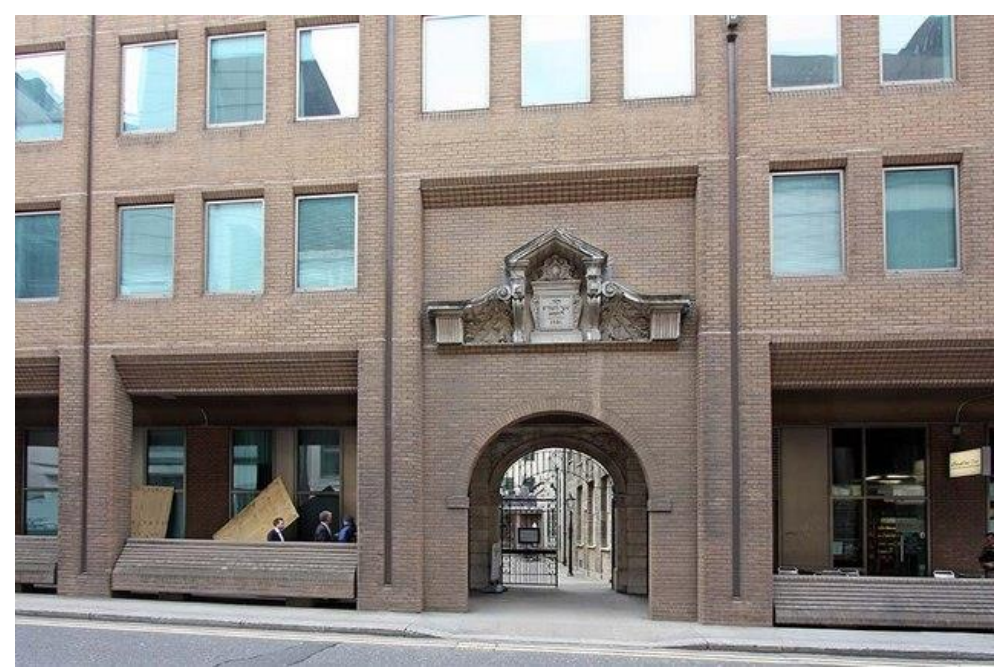

figure 34: Bevis Marks, London. Gate into courtyard, view from street (image: Wikipedia Commons)

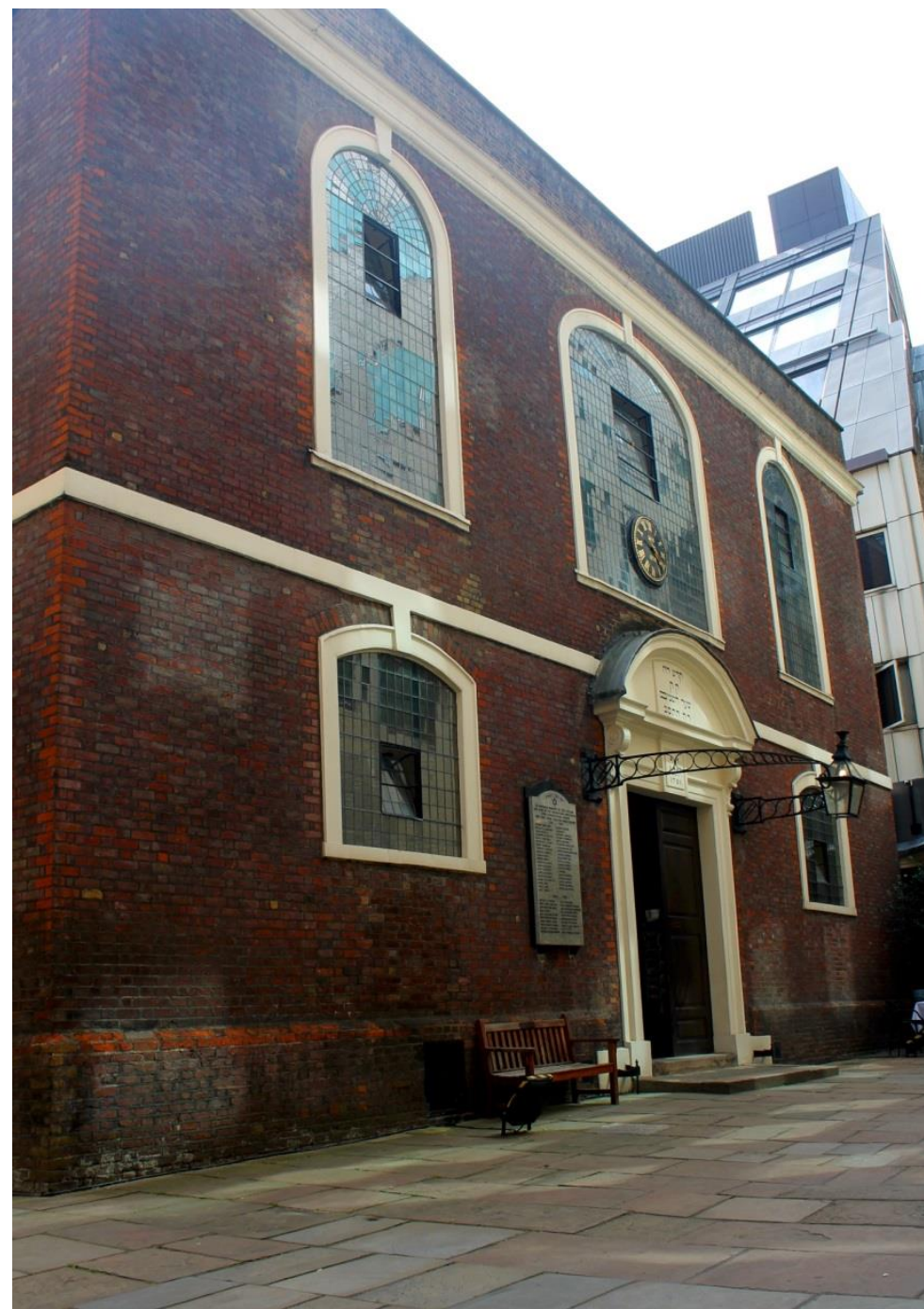

figure 35: Bevis Marks Synagogue, London. Main entrance and elevation (image: author) 


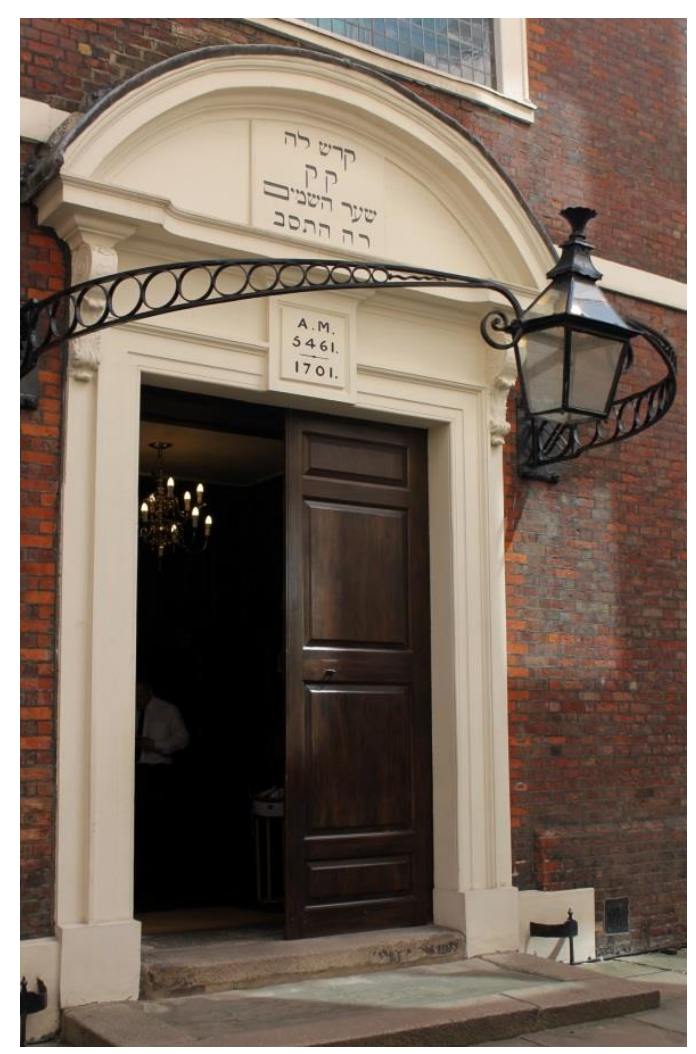

figure 36: Bevis Marks Synagogue, London. Front entrance. (image: author)
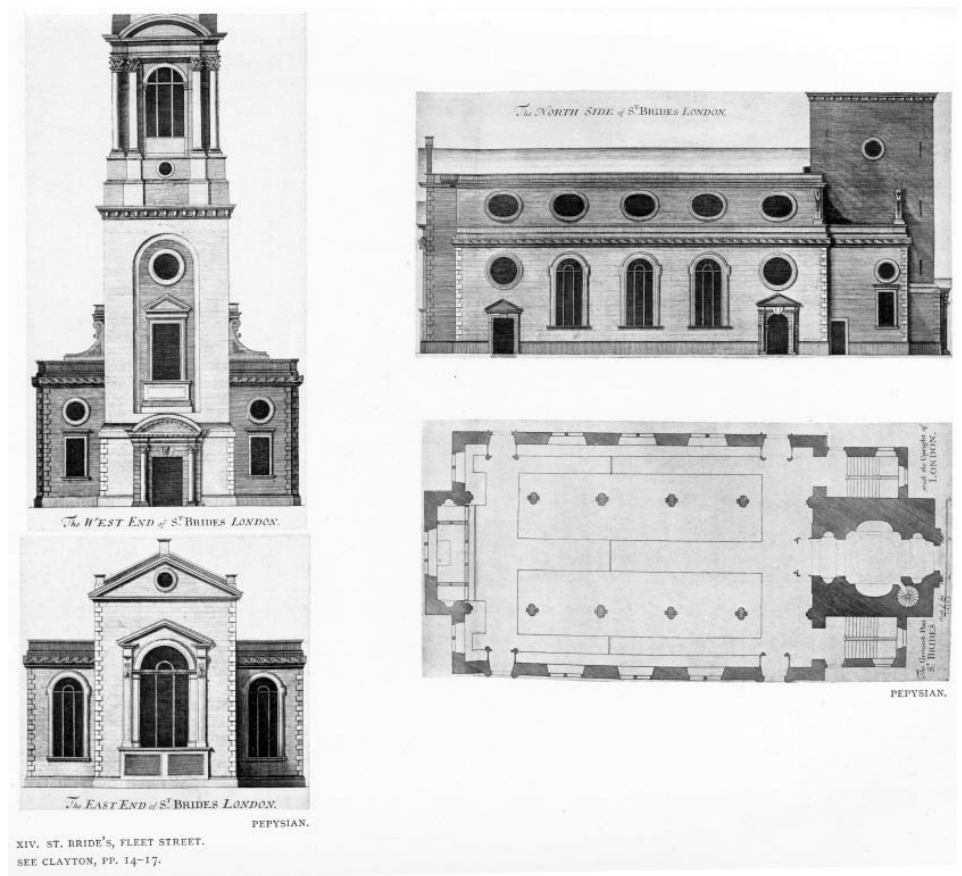

figure 37: St. Bride's, Fleet Street, London. Exterior elevations and plan. (image: Wren, Christopher. "The Parochial Churches of Sir Christopher Wren, 1666-1718." In Publications, $v$. 9-10, edited by Arthur T Bolton and H Duncan Hendry. Oxford: Printed for the Wren Society at the University Press, 1932.) 


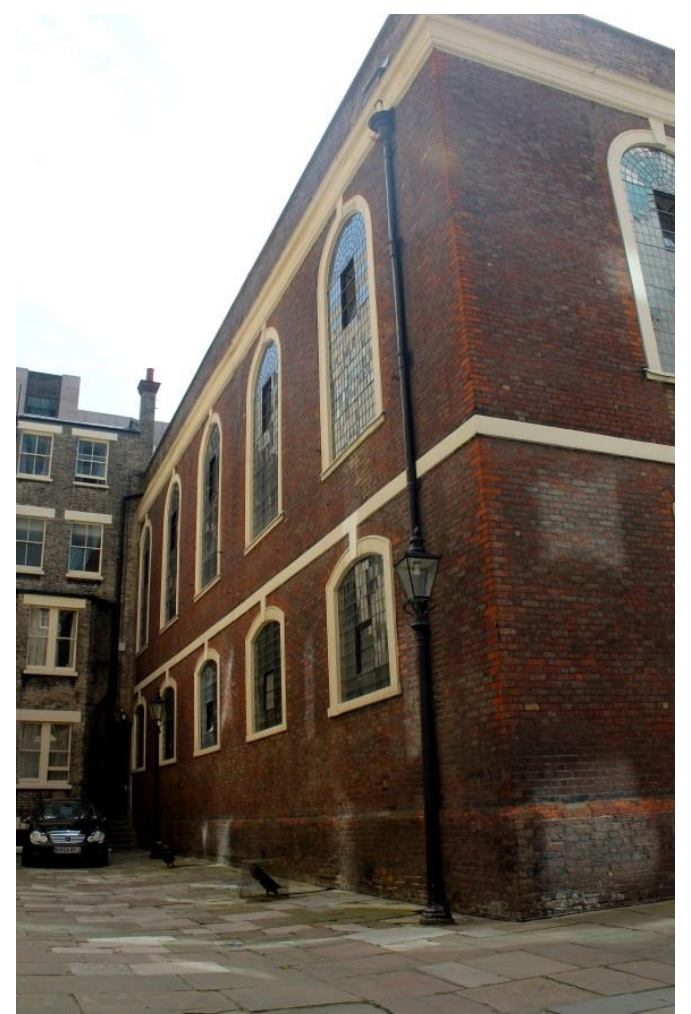

figure 38: Bevis Marks Synagogue, London. North exterior elevation. (image: author)

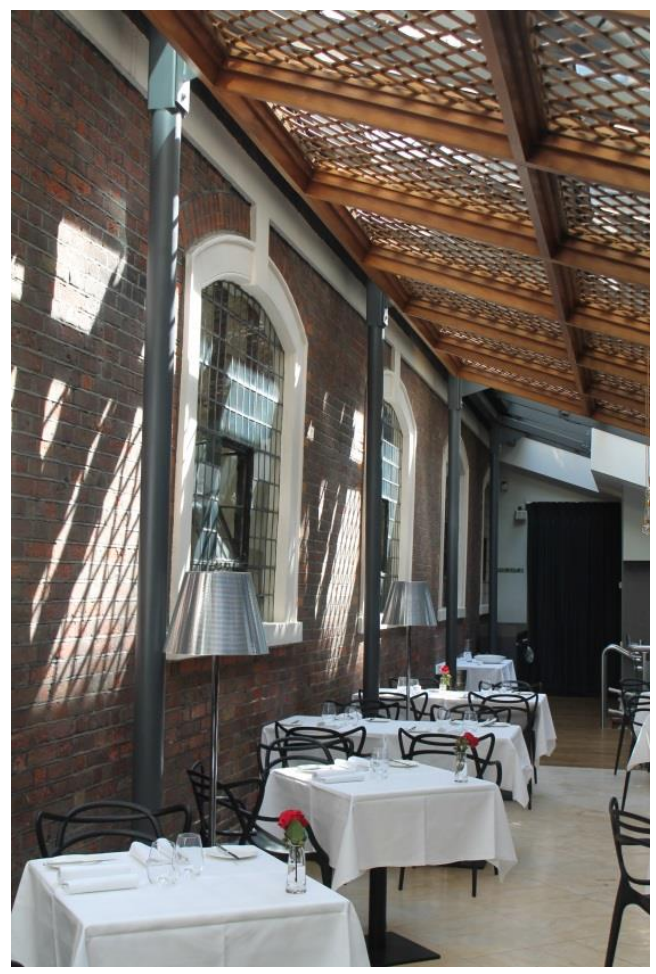

figure 39: Bevis Marks Synagogue, London. South exterior elevation (now part of restaurant on site) (image: author) 


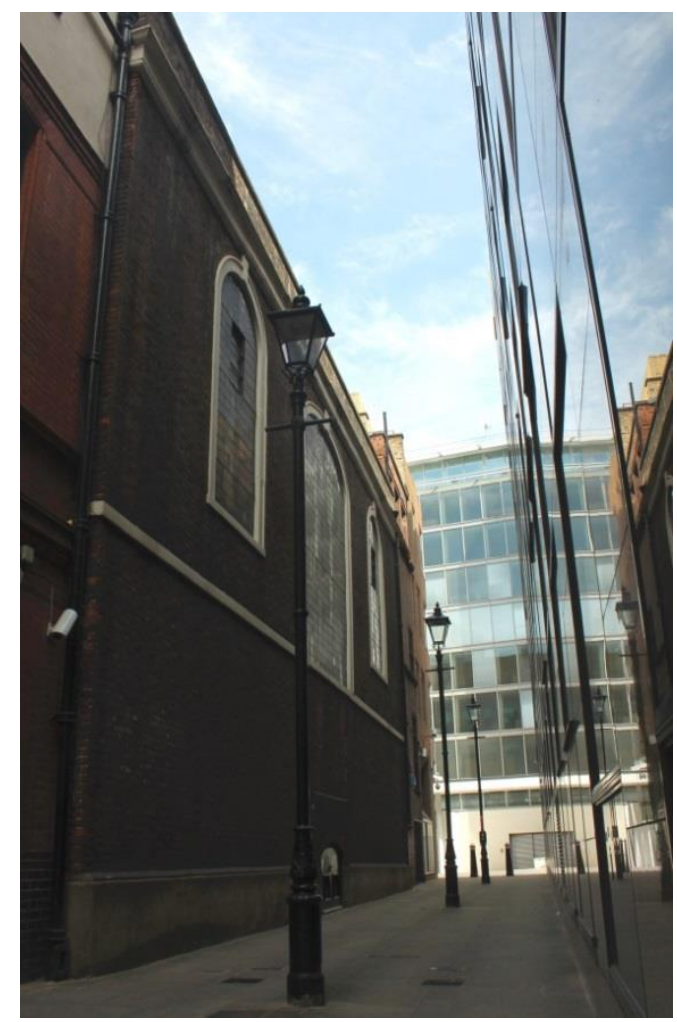

figure 40: Bevis Marks Synagogue, London. West exterior elevation, from Heanage Lane (image: author)

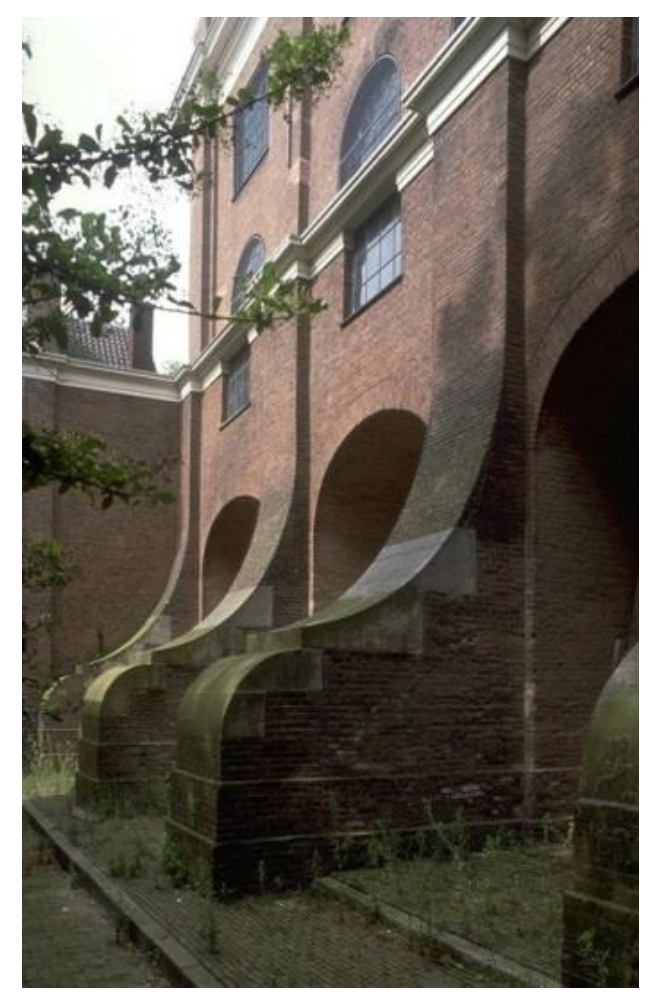

figure 41: The Spanish and Portuguese Synagogue (Esnoga), Amsterdam. Buttressing detail. (image: Wikimedia Commons) 


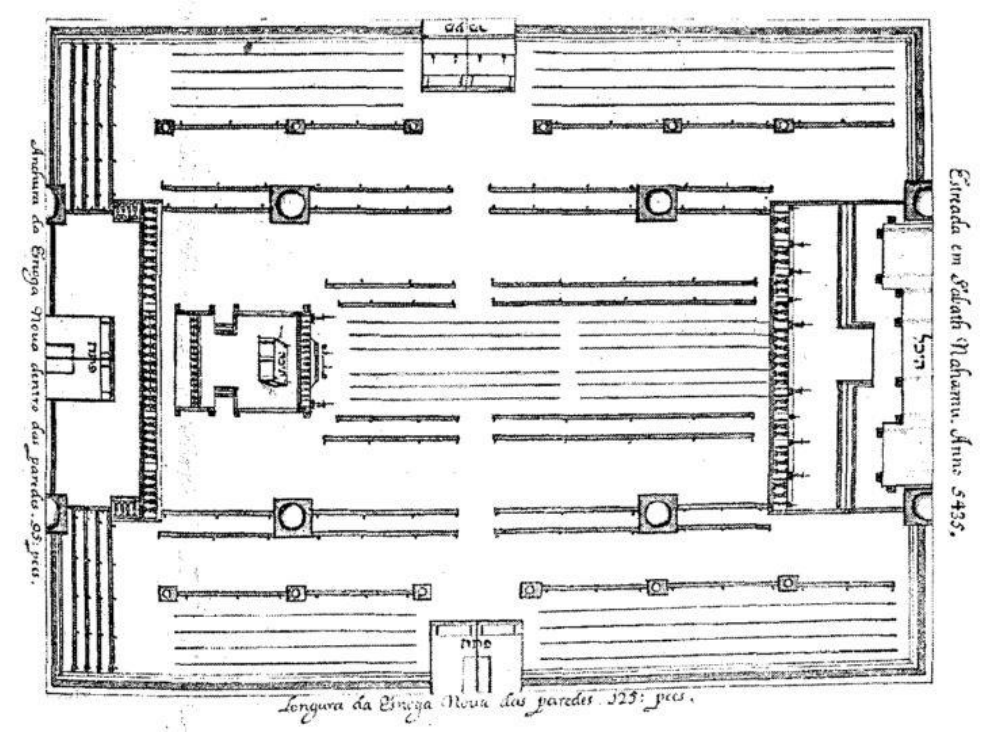

figure 42: The Spanish and Portuguese Synagogue (Esnoga), Amsterdam. Ground floor plan, from the engraving by Romeyn de Hooghe (1645-1708) celebrating its opening in 1675. (image: Rubens, Kenneth. "Bevis Marks Synagogue and the City Churches." Transactions of the Jewish Historical Society of England 37 (2002): 117-31.)

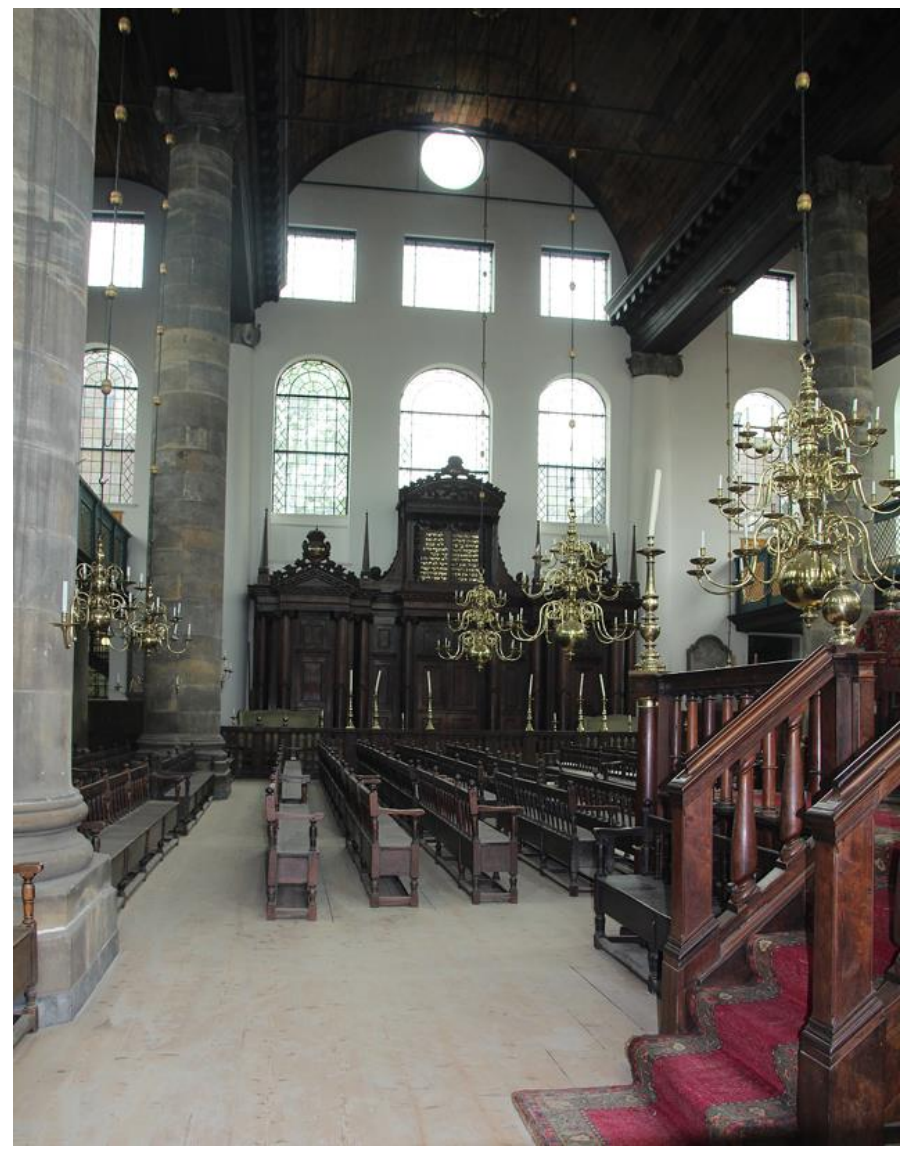

figure 43: The Spanish and Portuguese Synagogue (Esnoga), Amsterdam. Interior view east towards Ark (Echal) (image: Wikimedia Commons) 


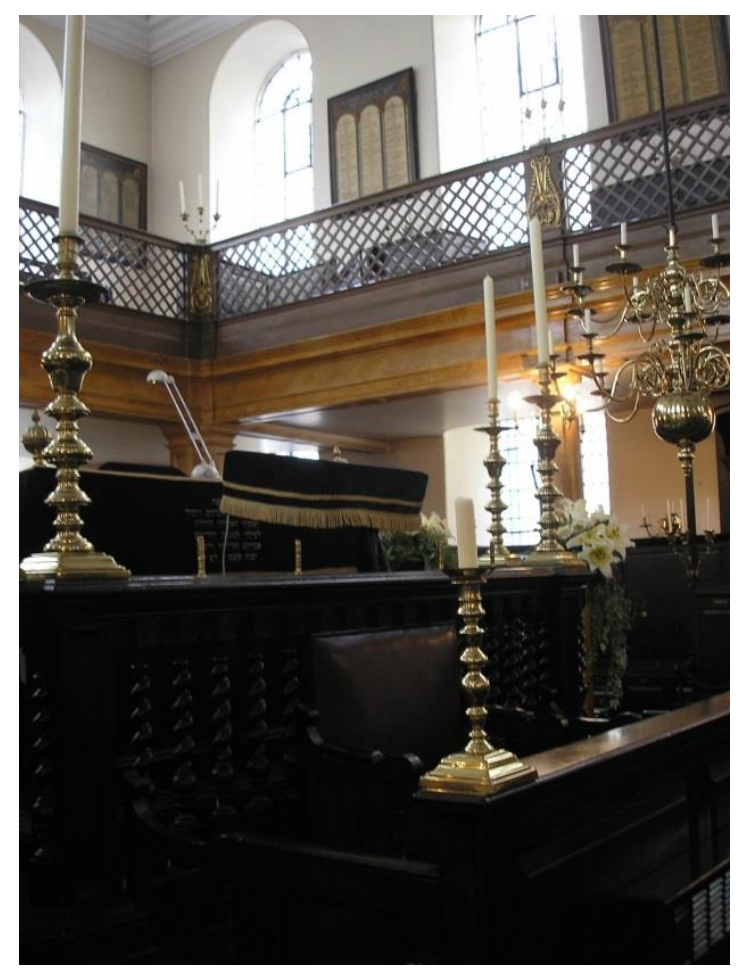

figure 44: Bevis Marks Synagogue, London. Reading desk (bimah) and candles. (image: author)

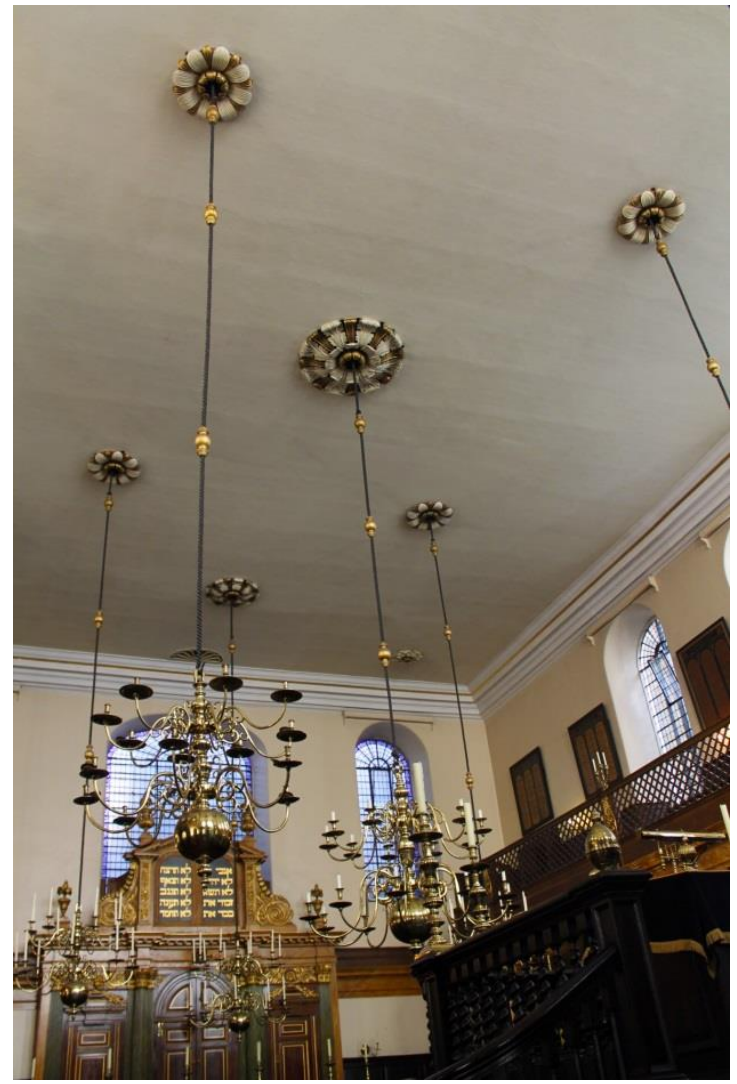

figure 45: Bevis Marks Synagogue, London. Ceiling rosette details. (image: author) 


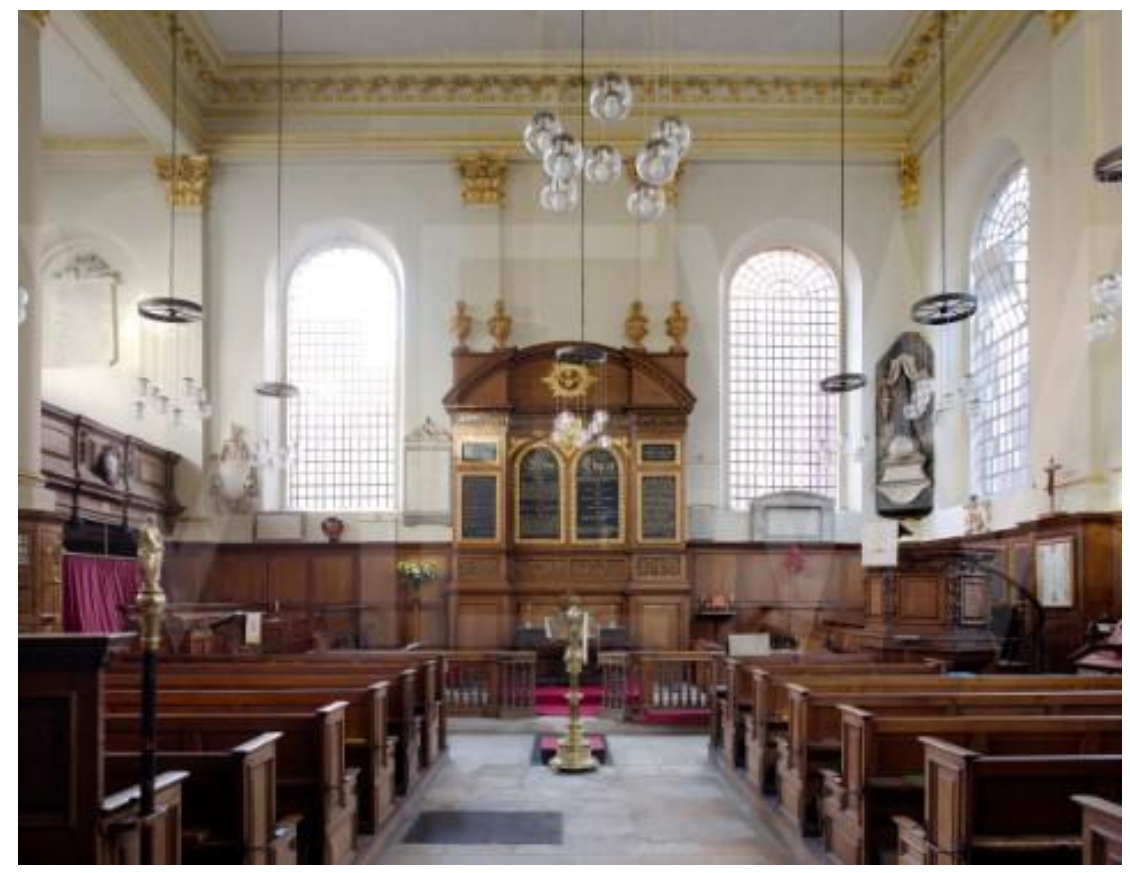

figure 46: St Benet Paul's Warf, London. Interior view towards east altar (image: author)

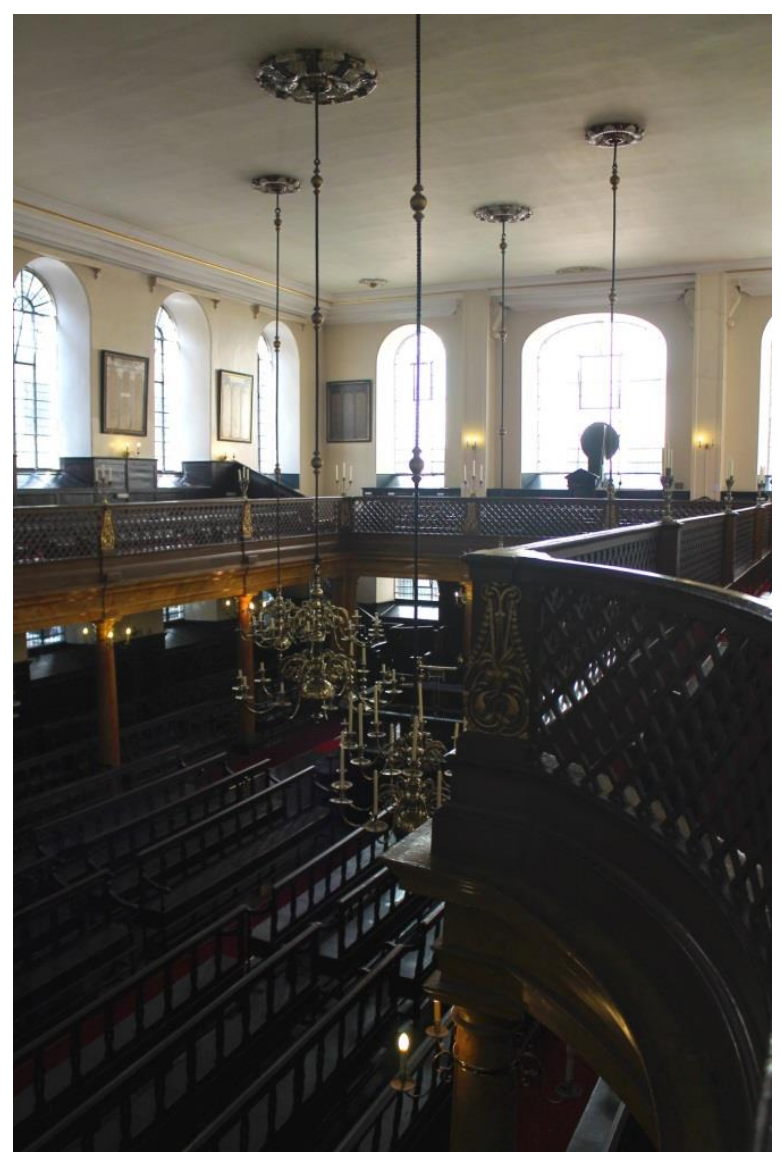

figure 47: Bevis Marks Synagogue, London. West interior view, including curved railing and other details (image: author) 


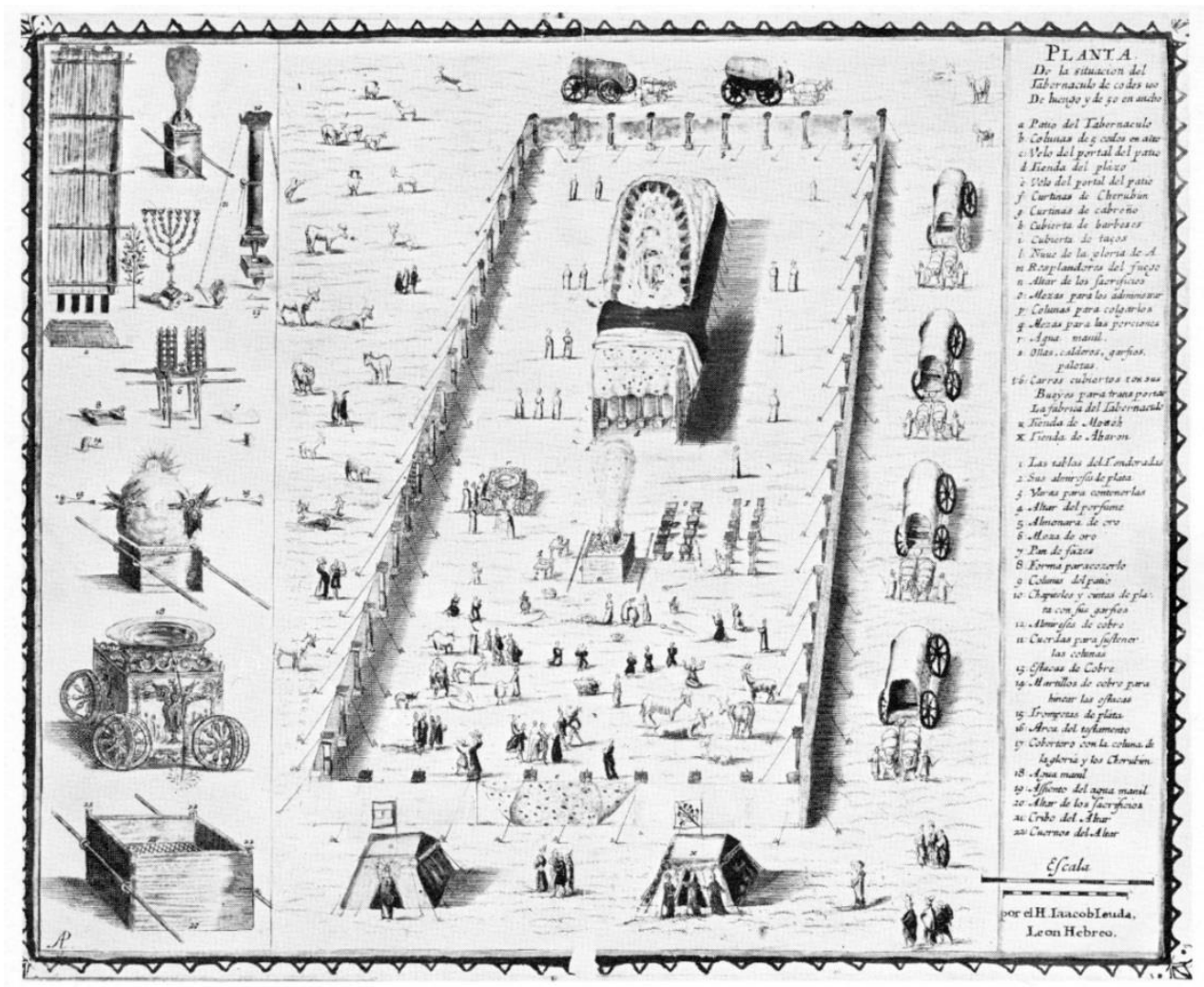

figure 48: View of the Tabernacle of Moses, ritual objects, and wagons of the Israelites. Illustration printed in Retrato del tabernaculo de Moseh, Amsterdam, 1654 (image: Rosenau, Helen. Vision of the Temple: The Image of the Temple of Jerusalem in Judaism and Christianity. London: Oresko Books, 1979.)

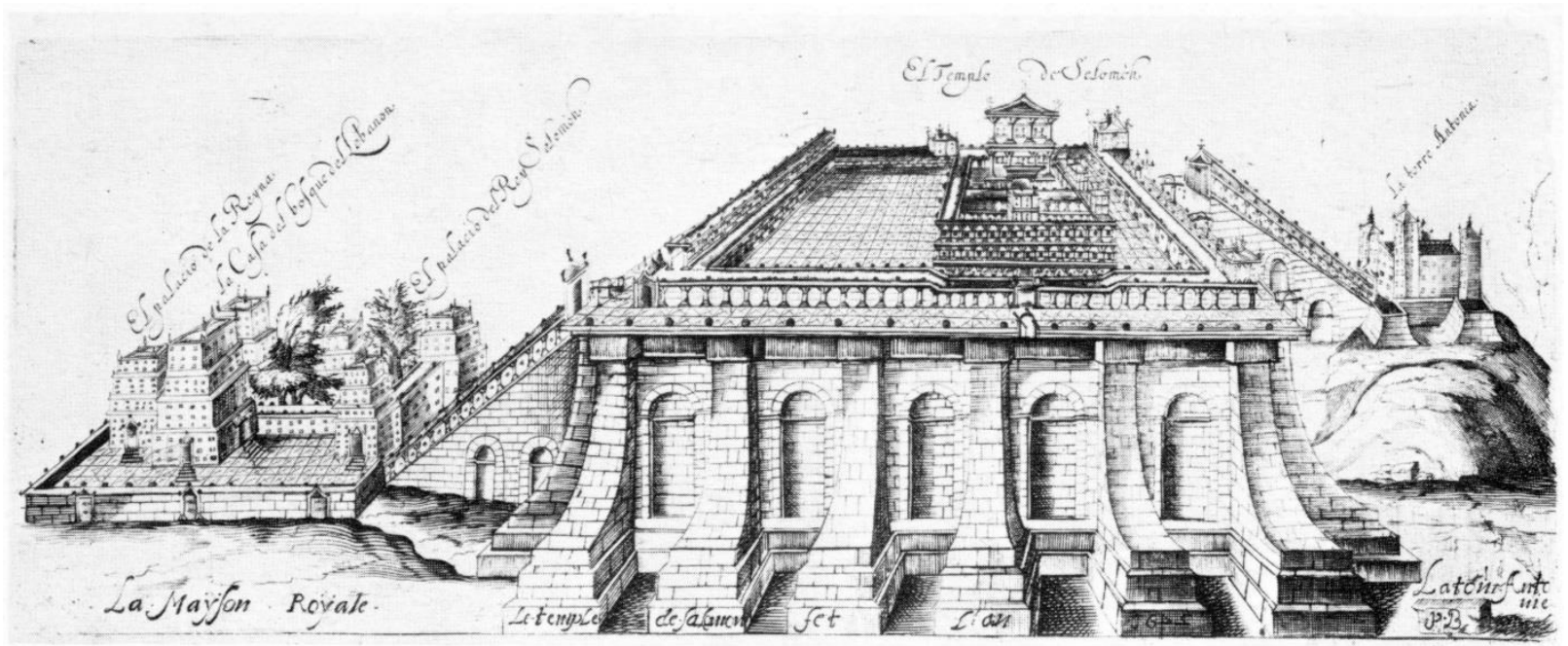

figure 49: Depiction of Solomon's Temple Complex, illustration printed in Retrato del tabernaculo de Moseh, Amsterdam, 1654 (image: Rosenau, Helen. Vision of the Temple: The Image of the Temple of Jerusalem in Judaism and Christianity. London: Oresko Books, 1979.) 


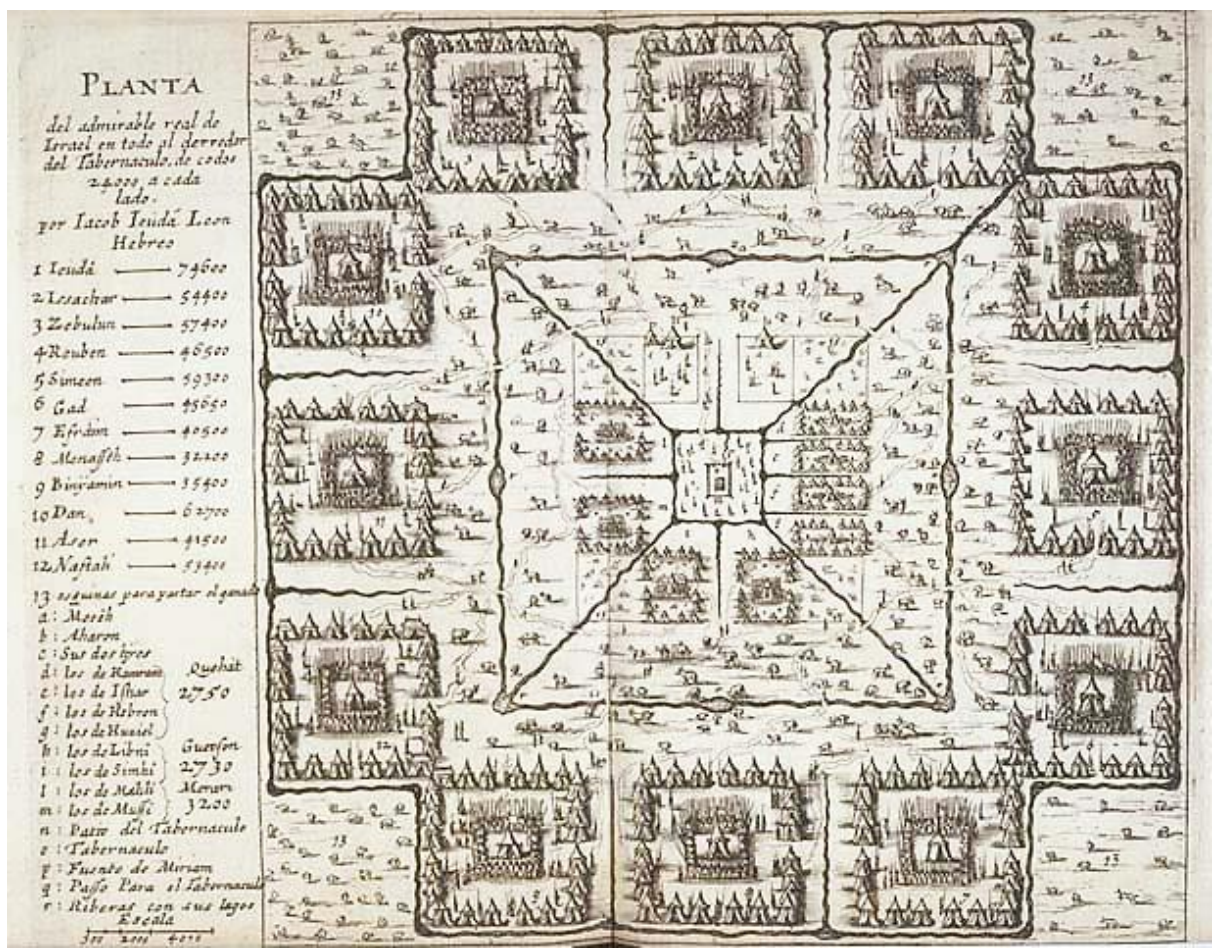

figure 50: Depiction of Tabernacle of Moses, illustration printed in Retrato del tabernaculo de Moseh, Jacob Judah Leon, Amsterdam, 1654 (image: http://www.mhs.ox.ac.uk/)

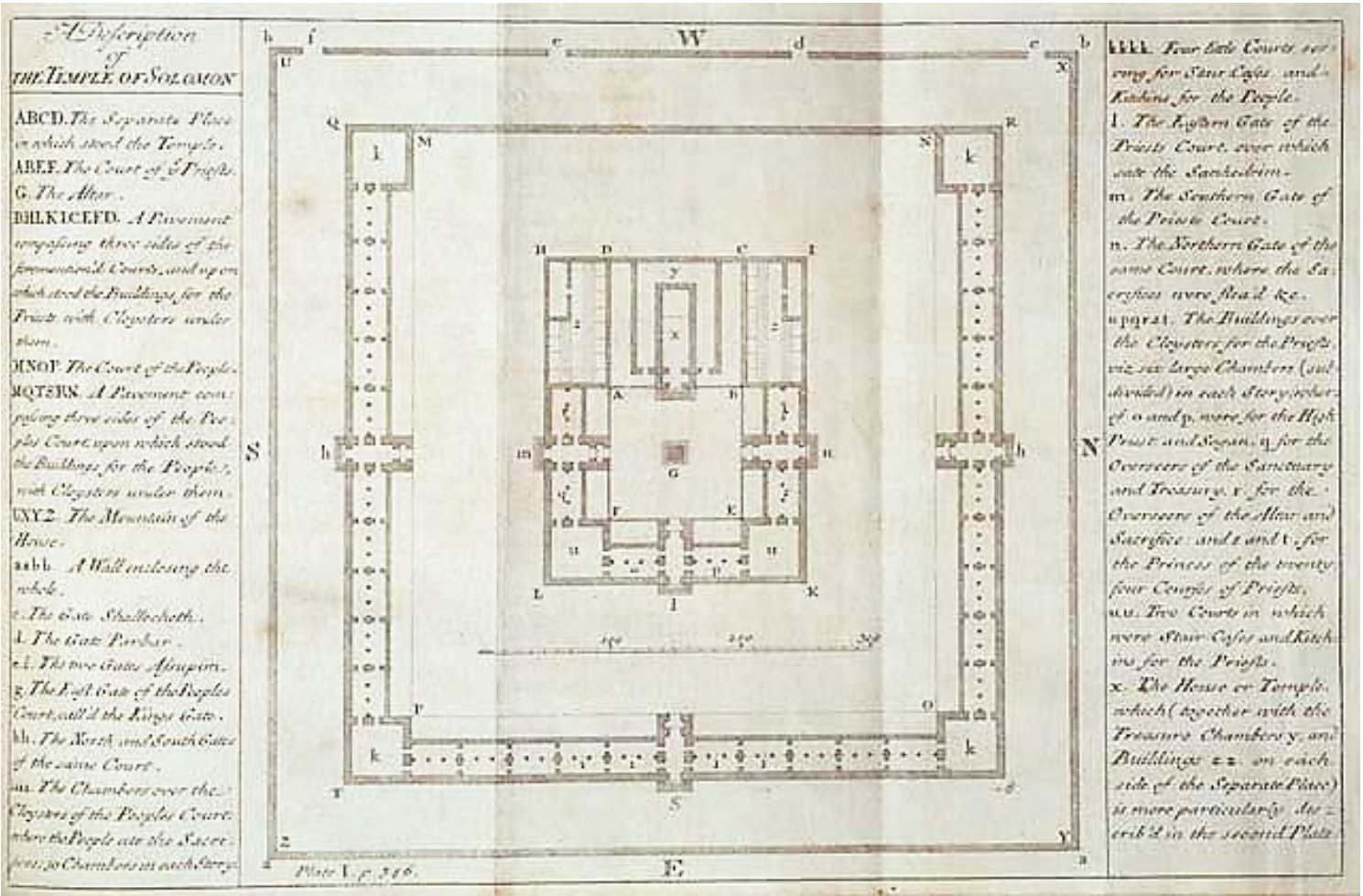

figure 51: Diagram of Solomon's Temple by Isaac Newton, Chronology of Ancient Kingdoms Amended (image: http://www.mhs.ox.ac.uk/) 


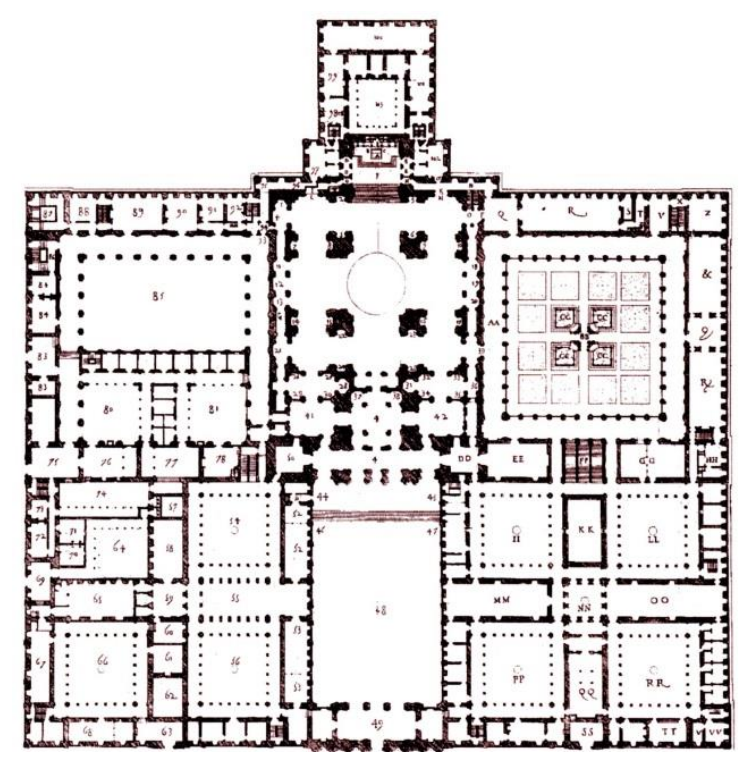

figure 52: El Escorial, Spain. Ground plan based on depictions of Solomon's Temple Complex (image: Wikipedia Commons)

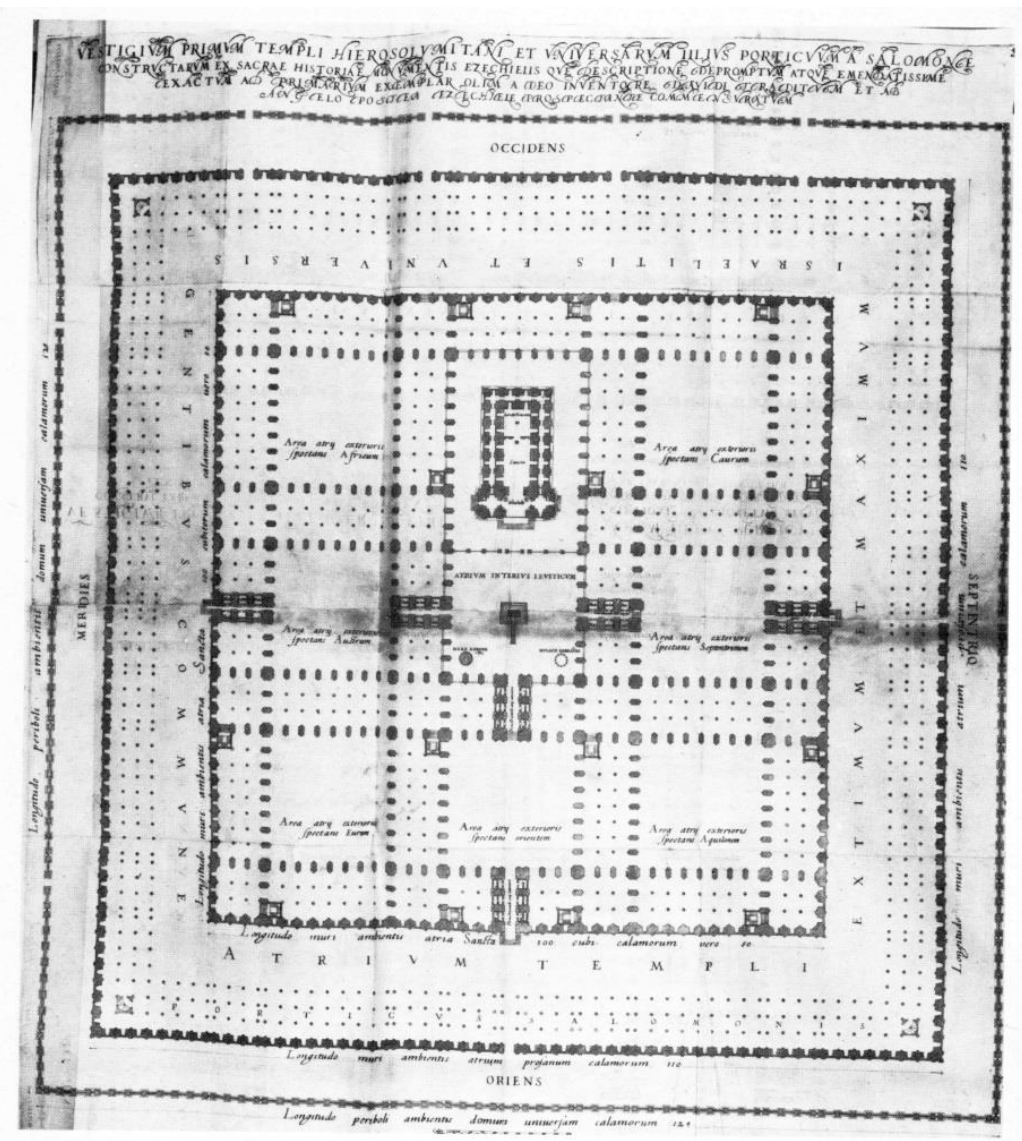

figure 53: Ground plan of Temple Precincts, Plan of Solomon's Temple Complex, Juan Bautista Villalpando, In Ezechielem Explanationes (image: Rosenau, Helen. Vision of the Temple: The Image of the Temple of Jerusalem in Judaism and Christianity. London: Oresko Books, 1979.) 


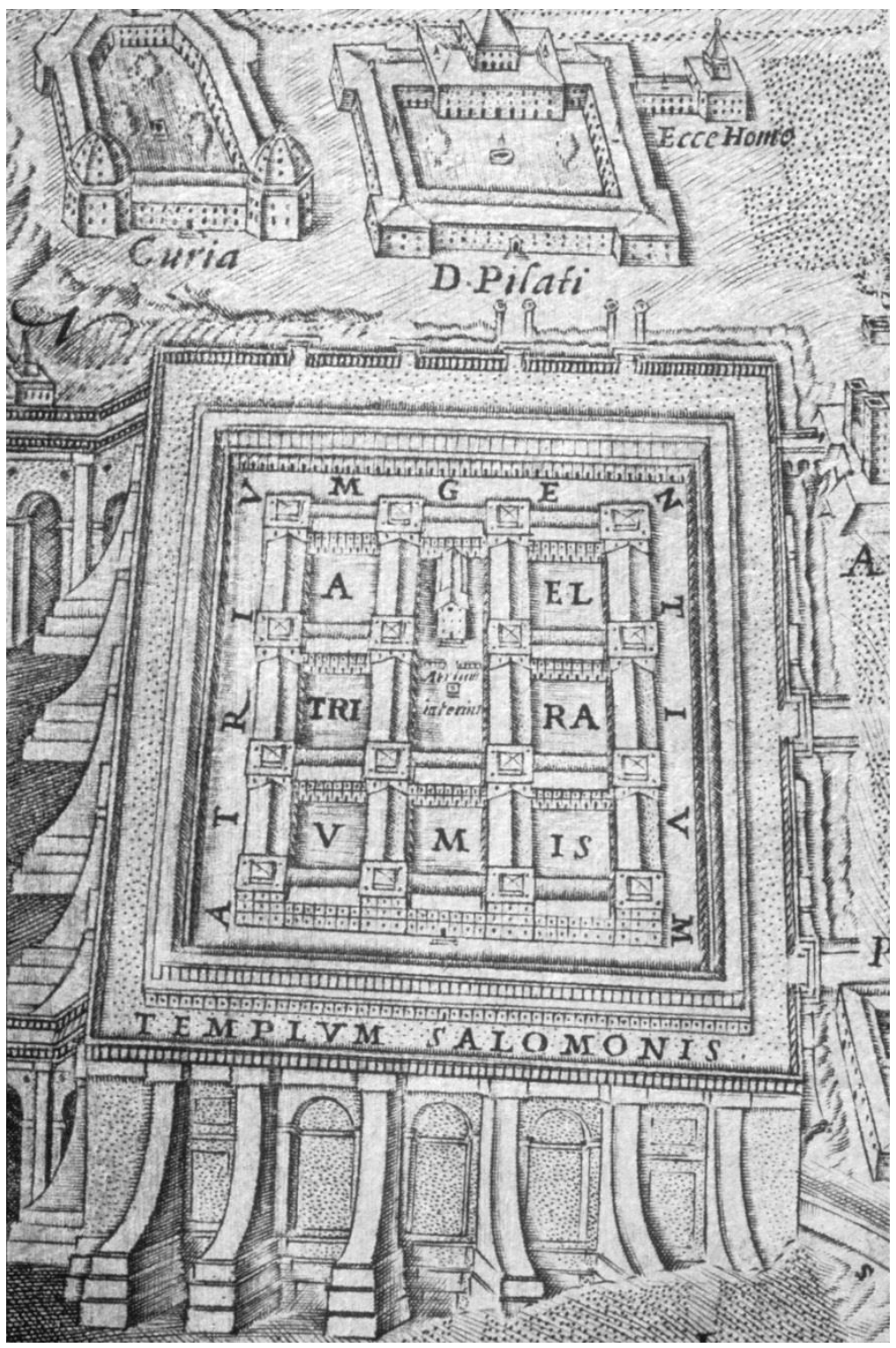

figure 54: Detail of Solomon's Temple Complex, Juan Bautista Villalpando, In Ezechielem Explanationes ( image: http://www.mhs.ox.ac.uk/)

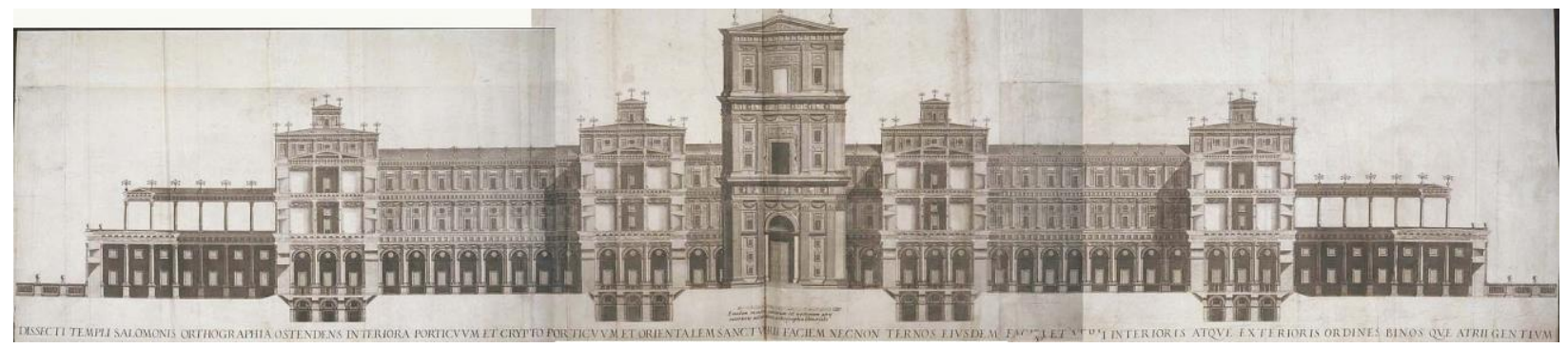

figure 55: Solomon's Temple Elevation, Juan Bautista Villalpando, In Ezechielem Explanationes (image: http://www.mhs.ox.ac.uk/) 


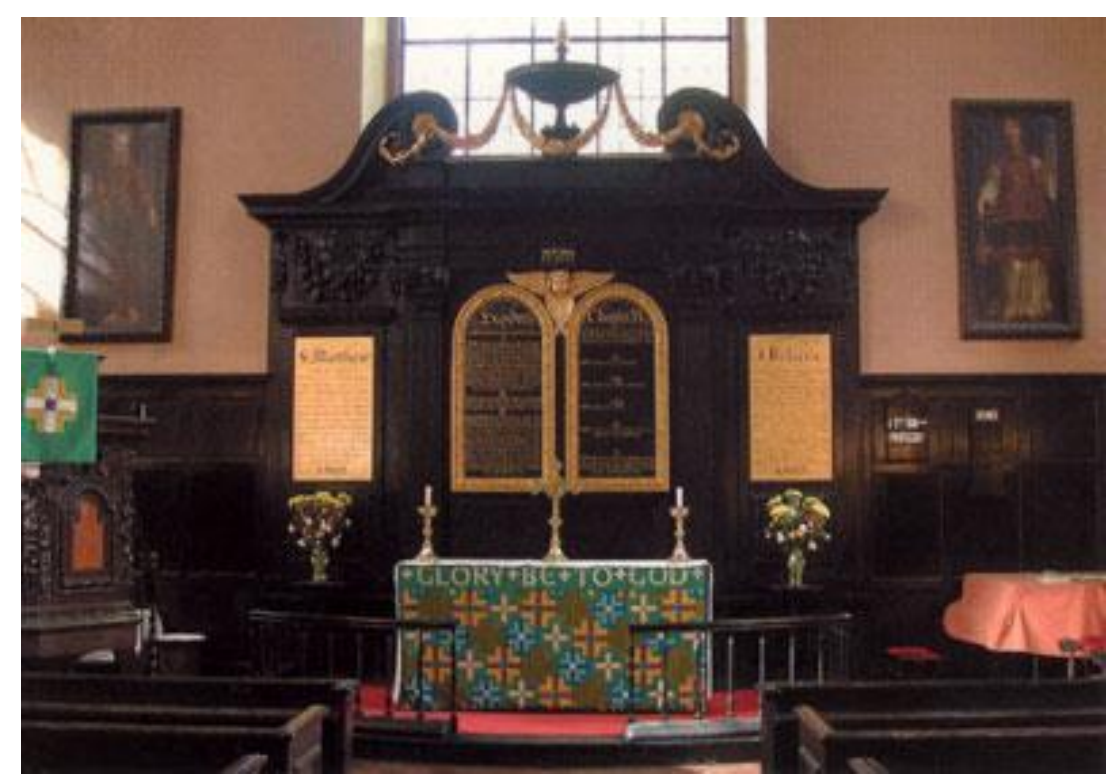

figure 56: Reredos with Tablets of Law, flanked by paintings of Biblical figures Aaron and Moses. St Anne and St Agnes church in London (image: Wikimedia Commons)

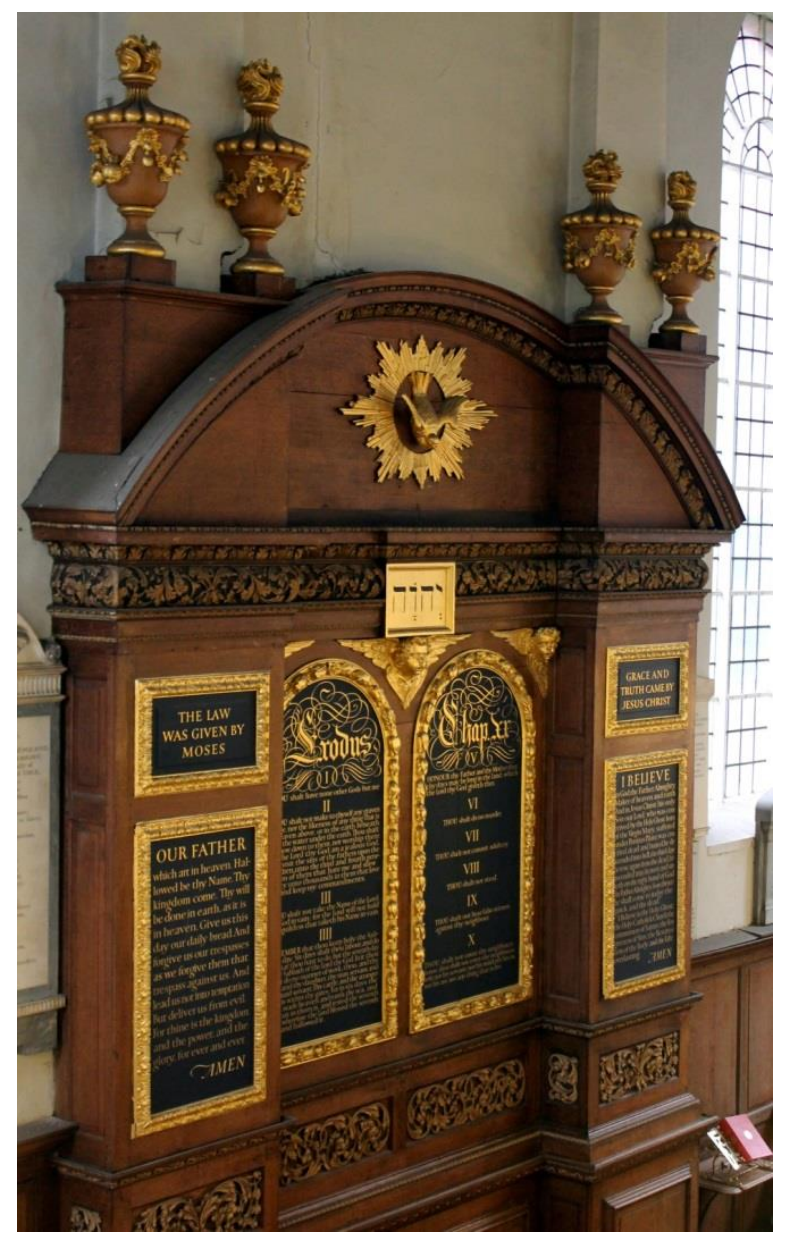

figure 57: St Benet Paul's Warf, London. Reredos including Tablets of Law. (image: author) 


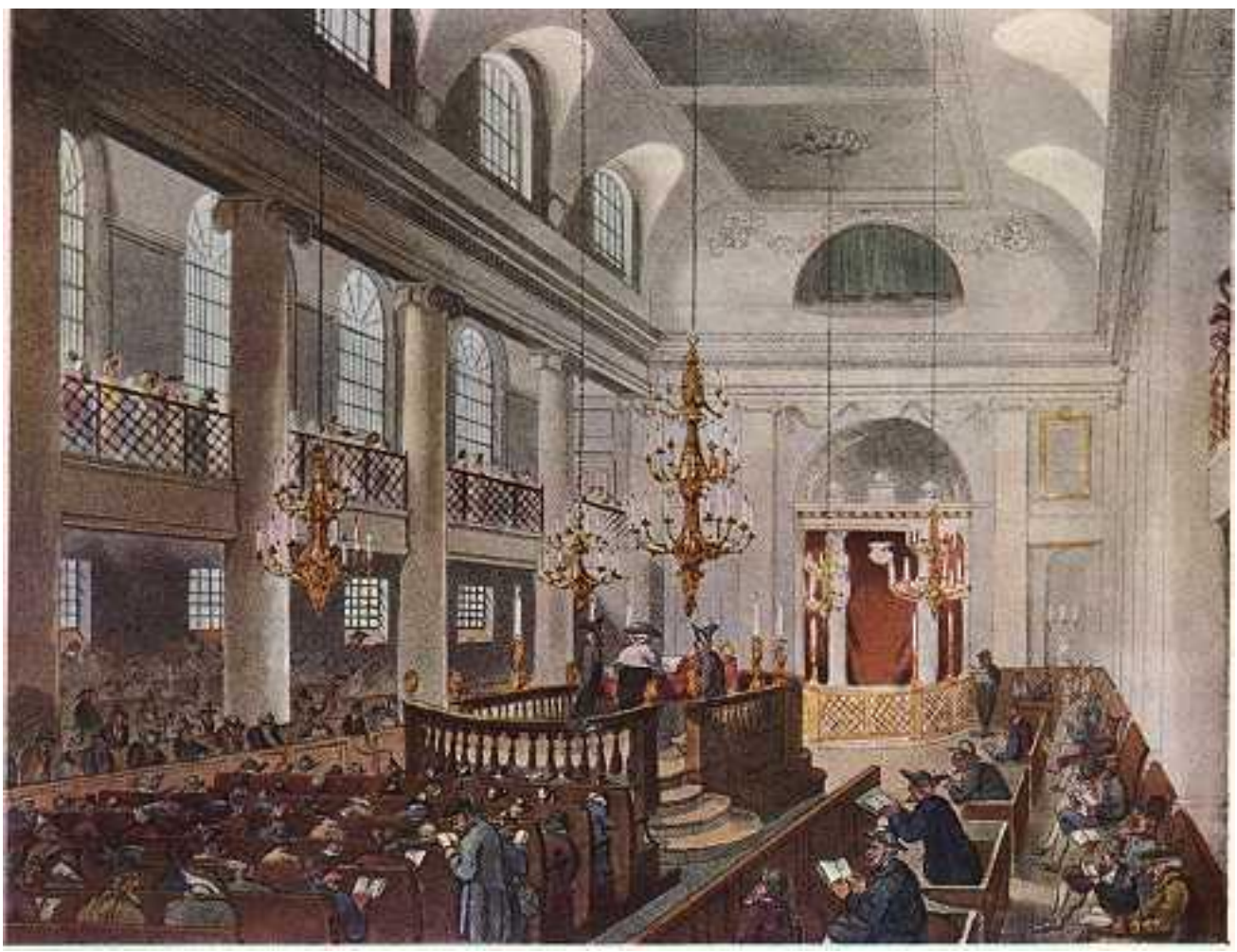

figure 58: Ashkenazi Great Synagogue of London, destroyed during WWII. Engraving by Pugin, published in Microcosm of London (1810) (image: Wikimedia Commons) 